


\title{
THE DOWNTOWN DISTRICT OF LEADVILLE, COLORADO
}

\author{
BY \\ SAMUEL FRANKLIN EMMONS \\ AND \\ JOHN DUER IRVING
}

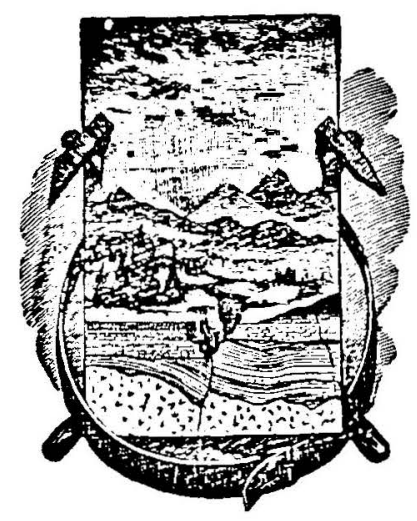

LIBRARY

TEXAS TECHNOLOGICAL COLLEGE $W$ ASH I NGTOZPCK, TEXAS 



\section{CONTENTS.}

- Page.

General geology . . . . . . . . . . . . . . . . . . . .

Principal features. . . . . . . .

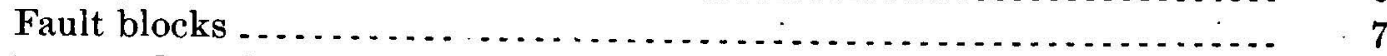

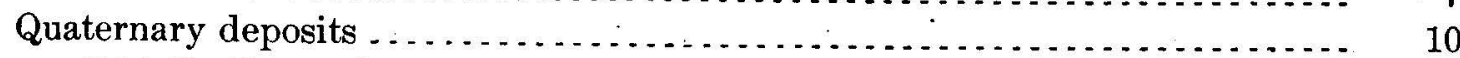

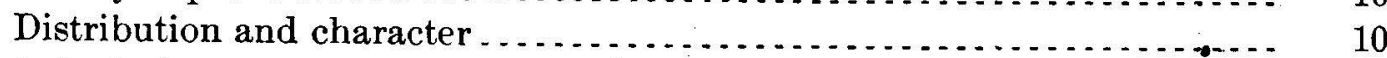

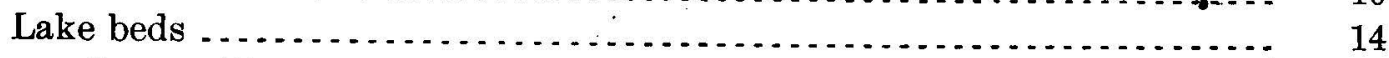

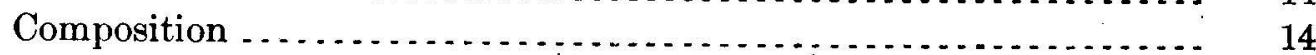

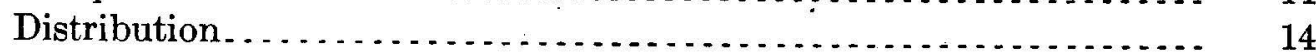

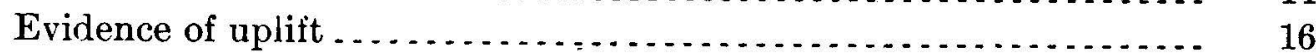

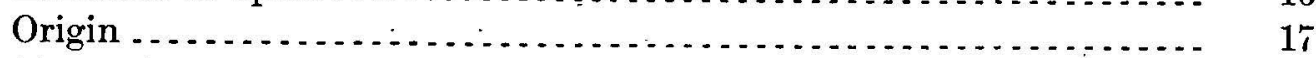

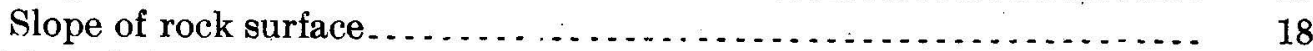

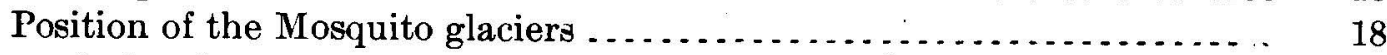

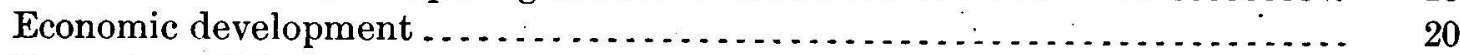

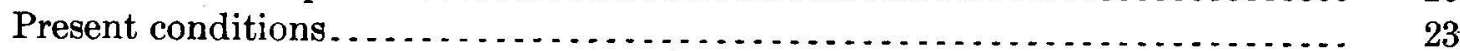

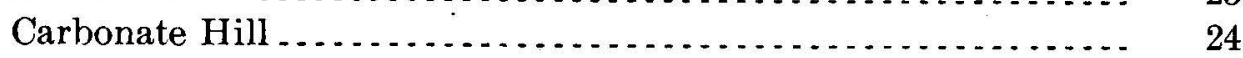

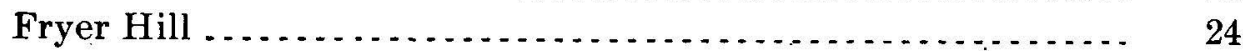

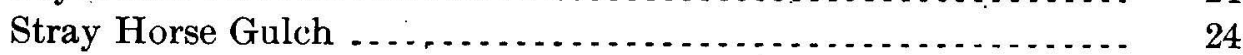

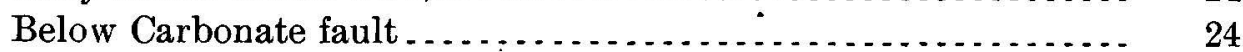

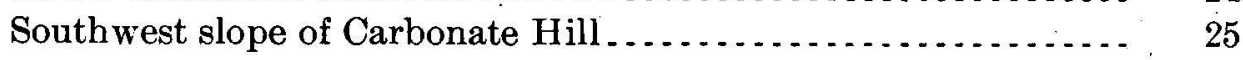

Bench below Pendery fault .................... 25



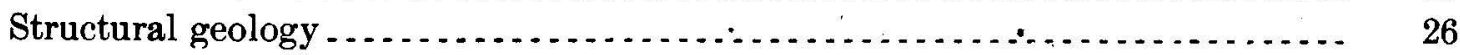

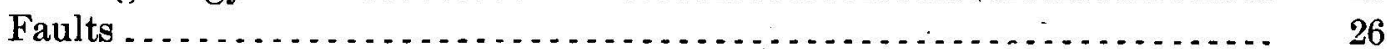

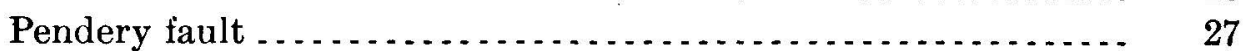



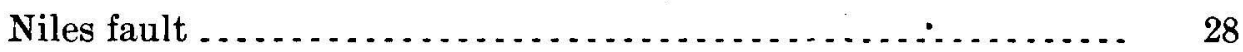

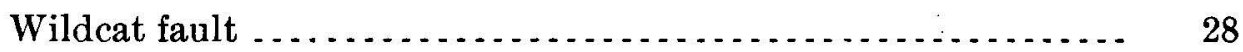



Weldon fault. . . . . . . . .

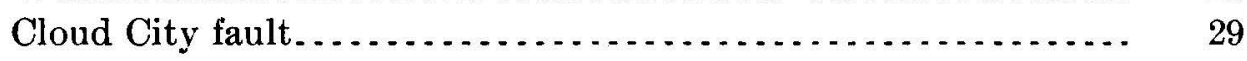

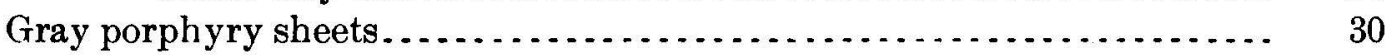

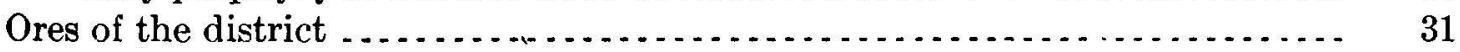

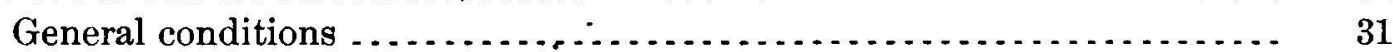

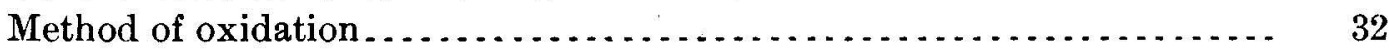

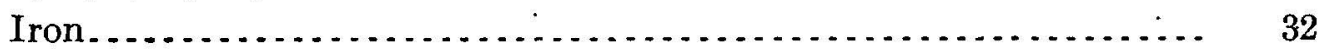

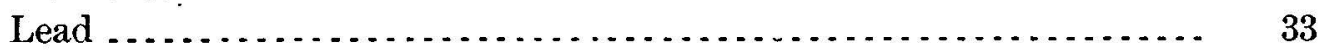

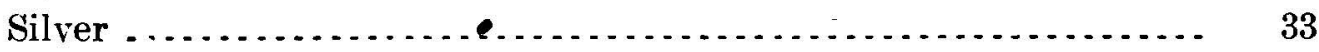

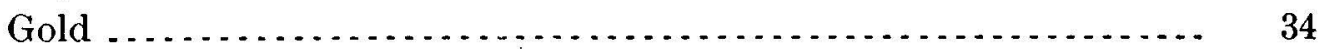



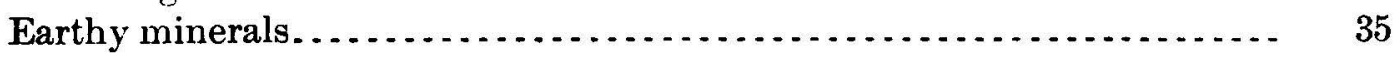


Page.

Distribution of ore..........

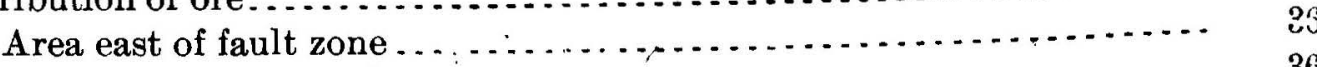

Carbonate Hill $\quad 36$

Stray Horse Gulch depression. ........................ 39

Fryer Hill

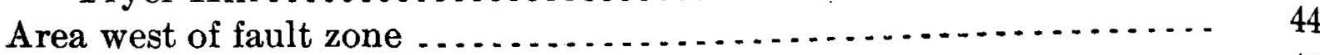

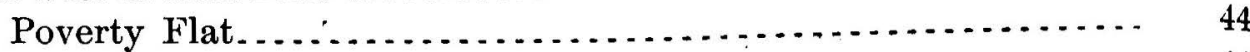

Capitol Hill ridge .................................. 44

Coronado and Sixth Street ground ...................... 46

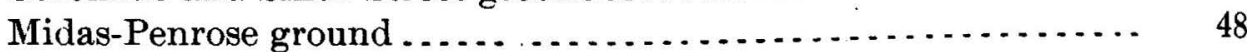

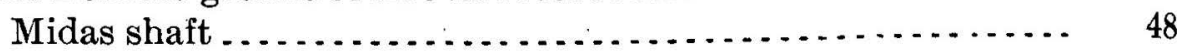

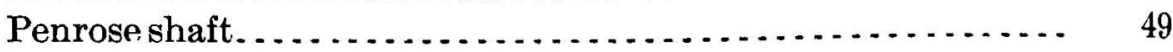

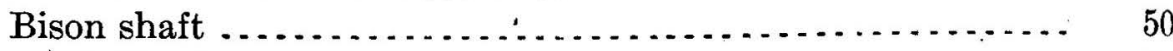

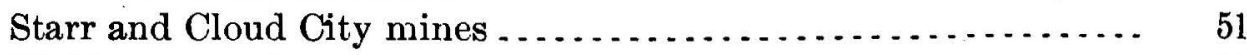

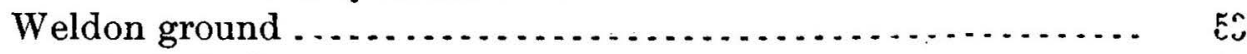

No. 1 shaft......................................... 53

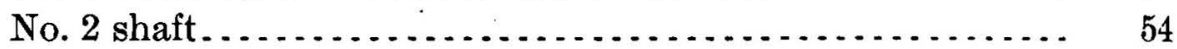

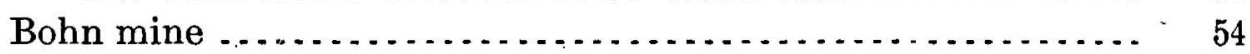

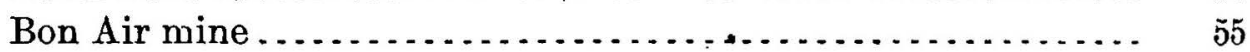

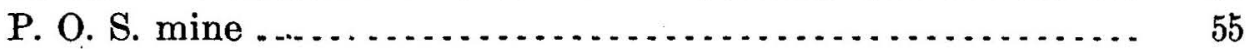

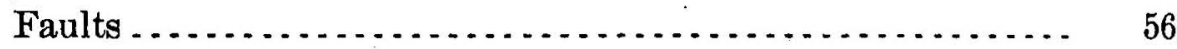

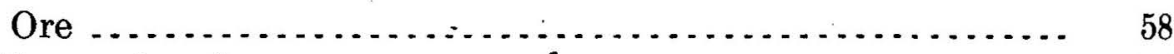

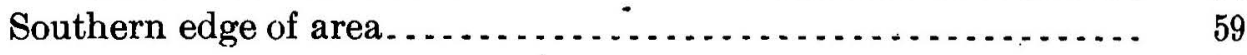

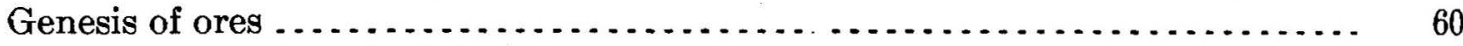

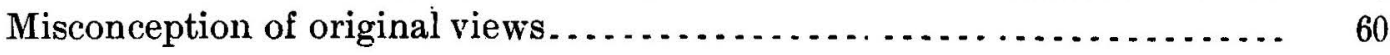

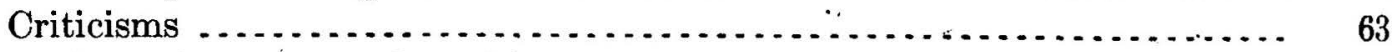

Modern views on ore deposition . . . . . . . . . . . . . . . . . . . . . 66

Present views on genesis of Leadville ores. . . . . . . . . . . . . . . . . . . 67

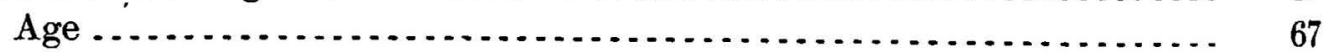



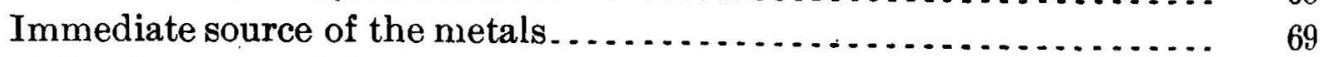

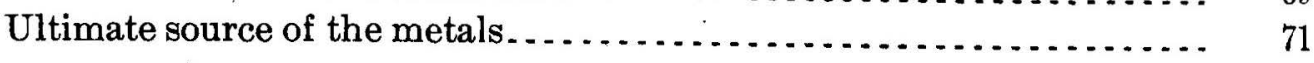

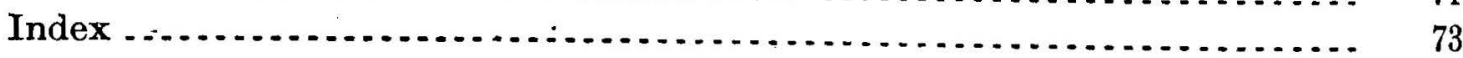

\section{ILLUSTRATIONS.}

Plate I. Geological map of Downtown district of

II. Sections on lines I and

III. Sections on lines III and IV

IV. Sections on lines V and VI, Pl. I

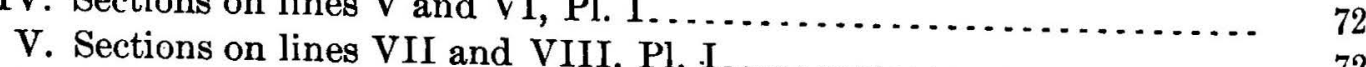

VI. Sections on lines IX and X, Pl. I

VII. Sections on lines XI and XII, Pl I $\ldots$

Fig. 1. Section through Cloud City and Starr shafts $\ldots \ldots \ldots \ldots \ldots \ldots \ldots \ldots \ldots$

2. Plan of P. O. S., Midland and Can mingts .................. 52

3. Workings of P. O. S mine and Can mines .................... 56

4. Workings of P. O. S mine

5. Diagrammatic section of 


\title{
THE DOWNTOWN DISTRICT OF LEADVILLE. COLO.
}

\author{
By S. F. Emmons and J. D. Irving.
}

\section{INTRODUCTION}

The present sketch and the accompanying map and sections are presented in advance of publication of the revised maps of the entire Leadville district because the underground data on which they are based have been in great measure determined by the actual observation of one or both of the two authors and are therefore more readily compiled than the data concerning the other parts of the areas mapped, where there are considerable portions with regard to which the information is either less certain or altogether wanting. This preliminary publication is also made for the further reason that the information herein contained is likely to be more immediately useful to those engaged in mining at Leadville, since, on account of the deep covering of gravel beds, it is difficult for them to form a sufficiently clear idea of the structural conditions of the rock mass beneath to enable them to explore to advantage for new ore bodies. It is hoped, moreover, that the criticisms that may be made by those actually engaged in mining in this area, who will necessarily be in possession of much later data than were accessible to the authors when they prepared the accompanying map, will be available in time to correct any obvious errors before its final publication in connection with the general map of the whole district. In preparing such a map it is found that in many parts of the area, owing to absence of underground workings, the relative positions of the different rock masses can be determined only by inductive reasoning from known facts in the nearest adjoining explored areas. The representations of such parts are more or less in the nature of surmises and will be subject to correction when those portions of the area are actually explored. That the reader may be able to judge of the relative accuracy of the maps or sections showing the different portions represented, the underground workings have been indicated in the cross sections by full lines when they are in the actual plane of the sections and by broken lines when they are near enough to 
this plane to afford accurate deductions. The reader must therefore bear in mind that the geological outlines given are accurate in proportion to their nearness to lines of underground exploration, and that when no such lines are represented the outlines are the result of deduction and are subject to correction in greater or less degree, according to their distance from underground areas actually explored. As no shafts or drill holes have yet reached the underground rock surface beyond the western edge of the area mapped, the uncertainties in the neighborhood of this line are necessarily the greatest of all, but lessen as known workings are approached.

The field observations on which this report is based and the maps and sections by which it is illustrated represent the labors of both authors combined, but the report itself is in the words of the senior author, who alone should be held responsible for its shortcomings.

\section{GENERAL GEOLOGY. \\ PRINCIPAL FEATURES.}

The city of Leadville is situated on a terrace at the foot of one of the western spurs of the Mosquito Range, near the head of the Arkansas Valley. The mines which have made the Leadville district one of the most important producers of silver, gold, lead, zinc, and iron in the West during nearly thirty years are mostly higher up on the spur, some at distances of 2 or 3 miles east of the town. Of late years, however, mining developments have been spreading westward under the terrace deposits on which Leadville stands, and the present map and accompanying text deal almost exclusively with these newly developed deposits.

To those who are familiar with the Leadville region any account of the general structure of the Mosquito Range would be quite superfluous, but as there may be some among the readers of this sketch who have not visited the region a very brief statement of its geineral features may be useful.

The Arkansas Valley from its head at Tennessee Pass to Salida, where it bends to the eastward, is a north-south depression of geologically recent date that lies between the Sawatch Range on the west and the Mosquito Range on the east. The Sawatch is an oval mass composed entirely of gneisses, granite, and schists, belonging to the crystalline complex on which the Cambrian and later sedimentary beds were deposited. The outcrops of the Paleozoic beds-the older portion of the sedimentary series-almost completely encircle the oval, lying in somewhat different positions on the different sides, but always dipping away from it, showing that it represents an older land mass.

The Mosquito Range is a north-south mountain range whose higher summits rise to elevations of 13,000 and 14,000 feet, consisting mainly 
of Paleozoic beds, with some Mesozoic beds along its eastern flanks, between the strata of which an immense amount of igneous rock, in the form of sheets or sills and laccoliths, was forced before the mountains were uplifted. The uplift of the range seems to have been caused by some force acting from the east westward, which has pushed the sedimentary series, with their included igneous intrusions, against the unyielding buttress of the Sawatch massif, compressing them into a series of asymmetrical anticlines, with the steeper side on the west, and, where the limit of flexibility of the rock masses involved was reached, breaking them by a series of north-south faults. During the entire period of wearing down by erosion which has elapsed since the uplift commenced the mountains have been slowly carved into their present form, and the great depression of the Arkansas Valley has been cut out approximately along the odd shore line on the east side of the Sawatch.

In that portion of the Mosquito Range in which the Leadville district is situated the igneous intrusions were unusually abundant, and in the dynamic movements which caused the uplift of the range faulting very greatly predominated there over folding, so that the resulting structure, as exposed by erosion, is found to be remarkably complicated, and the difficulty of correctly interpreting this structure has been greatly enhanced by the abundant covering of recent detrital material, largely glacial sands and gravels, which cover the lower slopes.

The Leadville district is thus broken by these faults into a series of fault blocks, in general marked on the surface by higher shoulders on the spurs, which have been locally designated as hills, such as Breece Hill, Iron Hill, Carbonate Hill, Fryer Hill, etc.

\section{FAULT BLOCKS.}

As has been explained at some length in the senior writer's original reports on this region, ${ }^{a}$ the Mosquito Range, on the western slopes of which the Leadville district is located, is a faulted-up moun tain mass of Paleozoic beds, resting on pre-Cambrian granites and gneisses. The faults run in a generally north-south direction, and, as shown where they are exposed in section in the deeper canyon cuts of the range, they are located as a rule along the steeper western limb of an anticlinal fold. The zone or block between two faults should thus have a synclinal structure. The main fault along which the range has been uplifted is called the Mosquito fault, and where it consists of a single fault plane it runs just west of the crest, its scarp forming the remarkably steep western face of that crest, which rises

a Abstract of report on geology and mining industry of Leadville: Second Ann. Rept. U. S. Geol. Survey (1880-81), 1832, pp. 201-290. Geology and mining industry of Leadville, Colo.: Mon. U.S. Geol. Survey, vol. 12, 1886. 
almost vertically for several thousand feet. In the Leadville region, however, displacement along this fault is distributed on no less than six approximately parallel faults, making as many fault blocks between the Arkansas Valley and the crest. In the original report the structure of the blocks immediately adjoining Leadville, as shown along the line of section $\mathrm{E}$, which runs through the town itself, is given as follows: ${ }^{a}$

In the region under Leadville, or from the western edge of the map to the Carbonate fault, a shallow synclinal; under Carbonate Hill, or from the Carbonate to the Iron fault, a second shallow synclinal; and from Iron Hill eastward a third, in all of which the prevailing dip is eastward, only a small portion of the eastern edge of the basin having a westerly dip. *** The effect of displacement produced by the faults has been to lift each successive block of ground up to the east of the fault.

Of these three faulted blocks those of Iron and Carbonate hills were defined to a certain extent on either side by outcrops, or by underground workings which had reached what is generally called in Leadville the "contact," or the upper surface of the Blue or Leadville limestone, beneath the great body of White porphyry. This is the important horizon to be determined, because beneath it the miner may commence his search for ore bodies and because the average thickness of the underlying sedimentary formations down to the basement complex of granite is well known. Of the third block, which stretches westward from the Carbonate fault and in which the city of Leadville is situated, only the eastern limit was dëfined, and that somewhat imperfectly, by the outcrops of Blue limestone along the west face of Carbonate Hill and by the few shafts that had disclosed the Carbonate fault and, at a single point, its parallel, the Pendery fault. To the west of this line the rock surface is buried beneath an accumulation of gravel beds which stretch from the base of Carbonate Hill in a gently sloping mesa, about 4 miles in width, to the Arkansas Valley at Malta, and whose thickness, inasmuch as it had not been penetrated by shaft or drill hole, was still a matter of surmise, although it was estimated to average at least 400 feet. To determine the structure of the underlying rock masses, and thereby to ascertain the extent of possible ore-bearing ground in this western block, constitutes to-day, as it did when the original study was made, one of the most interesting problems connected with the geology of the Leadville district. It is somewhat remarkable, moreover, that, considering the immense amount of underground exploration that has been carried on in the district during the twenty-five years that have elapsed since that time, so little has been accomplished toward determining the conditions beneath the Wash in the western portion of this area. Except that the limit of actually explored ground has been moved 2,000 to 2,500 feet westward, our knowledge of this 
unexplored area remains in very much the same condition that it did in 1881. Inasmuch, therefore, as what can be said of its geological structure will be largely a matter of induction, it will probably be well to review briefly the results obtained by the reasoning employed in making the original report, to note how far they have been found to be correct, and to observe to what extent and in what manner it has been necessary to modify them in the light of the knowledge gained by actual mining work during that period.

The principal modifications that have thus been found necessary in the original indications have to do mainly with two general features, namely, the later intrusive sheets of Gray porphyry and the faults. The probable character of such modifications was in a measure foreseen, but it would have been unwise to attempt to indicate them without more positive knowledge than was then obtainable. Thus, one sheet of Gray porphyry only was indicated as occurring generally about the middle of the Blue limestone, yet as extending, in some places, down to the Parting quartzite. In point of fact more than one such sheet is found at some places, and crosscutting sheets going from one horizon to another are numerous. Although their vertical range is found to extend through all of the sedimentary series, it is still true that the most important bodies occur within the Blue limestone. As will be shown later, these bodies, especially where they cut across the stratification, have exercised an important influence on the precipitation of ore from its solutions:

With regard to the faults, it has been found that, though the lines of outcrop of the principal structural faults have been in the main correctly indicated on the original map, there are in depth many faults of lesser importance, of most of which no indication can be seen at the surface, and that the displacement of many of the greater faults, especially in the lower or western region, has been distributed on a series of parallel fault planes, thus producing step faults. This is most markedly the case where the main fault plane has a reentering bend to the eastward.

In the structure of the interfault blocks folding is found to be less prominent than was indicated, the prevailing dip of the beds being eastward, while it is only in the vicinity of the fault on the eastern side of the block that the strata rise perceptibly toward the east, either in a series of steps where the fault is multiple, or in a steep slope where it is single. There is still enough bending, however, to show the correctness of the author's assumption that the faulting has been a result of the same kind of stress that produced folds, and that the reason that these gentle folds have so soon passed into faults is probably that the intrusion of the great porphyry sheets has made the whole series of beds less flexible and more liable to rupture. Furthermore, the fact that most of the shafts sunk in the Graham Park region have found a contact within less than 100 feet of the depth 
indicated on the original map sections proves that, under the circumstances, the synclinal theory was evidently the safest and most logical basis on which to construct the underground structure in this block.

For the unexplored portions of the western or Downtown block it is judged best to follow this general course of reasoning in determining the probable structure of the sedimentary beds that still rest upon the pre-Cambrian basement complex in the region west of Leadville.

As will be seen by an examination of the series of cross sections accompanying the map of the Downtown area, it is in the immediate vicinity of the zone of faults that the principal uplift of the Paleozoic beds has taken place. Where the fault movement has been distributed on several planes this uplift has formed a series of steps. Where the movement was along a single plane, as in the northern part of the Downtown area, there is a distinct western dip of the beds for a considerable distance from the fault plane and a decided indication of an anticlinal structure near the fault. If there are no other important faults to the west of those shown in the underground workings-and we have no right to assume their existence until they are actually proved-the Paleozoic beds may have an approximately horizontal position, with a probable gentle dip to the east. If this assumption be correct, the extent of the ore-bearing horizons to the west is largely dependent on the slope of the rock surface beneath the gravel beds, since if this is steep they will have been cut off by erosion much farther to the east than if it nearly corresponds with that of the underlying Paleozoic beds. In the latter case they would probably remain in very much the position in which they were left by the preglacial erosion of the Arkansas Valley. It is therefore important to understand as well as possible the character and manner of deposition of the gravel, or so-called Lake beds, and the probable condition of the rock surface at the time they were deposited. The next section will therefore present the evidence which has accumulated in late years with regard to these beds and the conclusions which it seems possible to draw therefrom as to the probable extension of the Paleozoic sediments.

\section{QUATERNARY DEPOSITS.}

\section{DISTRIBUTION AND CHARACTER.}

With the exception of the alluvial gravels of the present streams, the. Recent or Quaternary deposits of the Leadville area are of glacial origin. The glacial phenomena of the Mosquito Range in general are so extensive and so remarkably clear and well defined that they are worthy of special study, which the writer would have under- 
taken in the original report but that the more strictly economic phenomena were so complicated as to occupy all the time that could be devoted to the work. Their proper illustration, moreover, would have required a special map that would have rendered more cumbersome the already rather large atlas. In the absence of such a map no special chapters were devoted to these phenomena, which thus received a less adequate geological treatment than the facts in his possession warranted. These facts, as read by him, pointed to the existence in this region of two distinct glacial epochs, in each of which there were formed distinct glacial deposits in the Leadville area. It was further assumed that during the first glacial epoch the bed of the Arkansas River, which probably had followed about the middle of the valley, was blocked up by glacial ice and morainal gravels issuing from Lake Creek in the Sawatch Range, which pushed entirely across the valley to the lower slopes of the Mosquito Range, and that in consequence a glacial lake must have been ponded back in the Arkansas Valley above that point. When the water rose high enough to override this barrier it would have found outlet naturally at the lowest point-- the extreme eastern end of the barrier-and once started in the readily erodable gravels would have cut down its bed in the same general position, even after reaching the underlying bed rock. This would account for the fact that at the present day the river has cut its bed several hundred feet into the hard rock that forms the eastern spurs of the Mosquito Range at the town of Granite and below. It seemed probable, moreover, that the lowest point in the rock bed of the valley, or the original bed of the Arkansas River, might be farther west, under the morainal gravels that extend out into the valley opposite Twin Lakes. At the time of the original investigation-in 1879-1881-placer mining in the Twin Lakes region was not sufficiently advanced to prove the underground structure by shafts, but, as will be seen later, recent studies have shown that this assumption is probably correct.

At Leadville, and for 6 miles down the valley, the lower slopes of the Mosquito Range have the form of a remarkably regular terrace or mesa, with a slope of $2 \frac{1}{2}^{\circ}$ to $3^{\circ}$, that extends up to the steeper rock slopes of Carbonate, Dome, and Long and Derry hills, as the shoulders on the respective spurs are locally designated. Similar but less extensive and less well-defined terraces occur on the western side of the Arkansas Valley along the slopes of the Sawatch Range. The surface of these sloping mesas on the spurs of the Mosquito Range were found to be made up of rounded bowlders of the harder rocks that constitute the range, embedded in a matrix of gravel and clay that was locally called Wash. Shafts sunk through the Wash in these areas found under it a varying thickness of finer-grained stratified material, which was approximately coextensive with the 
area of the sloping mesa. To this stratified material the name "Lake beds" was given, on the assumption that it had been deposited in the lake supposed to have been backed up in the upper Arkansas Valley by the Lake Creek glacier, while the overlying Wash was supposed to be rearranged morainal material that had been washed down by the floods that resulted from the melting of the ice during the retreat of the earlier glaciers. Over the beds thus deposited the lateral moraines of the glaciers of the second glacial area extend in welldefined ridges, some of them over a mile in length, which are thus readily distinguished from the material deposited during the first glacial epoch.

The method of representation and the treatment of these deposits in the original report was admittedly not scientific nor logical, since on the general map of the Mosquito Range the whole area underlain by Lake beds was represented by the color of that formation; whereas, in point of fact, the surface is in part covered by moraines of the second period, and over the whole is a surface coating of bowlder wash. In the sections, however, the Wash was differentiated from the underlying Lake beds, though in the text the term Wash was made to include all unstratified material, as well as alluvial gravels. The reason for this method of treatment lay in the fact that the maps and accompanying report were primarily designed for the guidance of the miner, and if the Quaternary deposits, including as well the rock slide or angular material resulting from the disintegration of porphyries in place, which often as effectually masks the outcrop as do the moraines or stream gravels, had been represented on the surface map they would have covered so large a portion of the original area that it would have been impossible to represent the structure of the underlying rock in place, which had been carefully reconstructed from a study of the underground workings and was essential as a guide to the exploration of the miner.

In the early eighties, when this report was written, modern physiography, or physical geography, could hardly be said to have taken form, and it was the practice among geologists generally to class as lacustrine beds all recent material that is distinctly stratified, whether it had been actually deposited in still waters or had been washed down along steep slopes into a body of water. The objections to this practice were very forcibly pointed out in 1900 by. Prof. William M. Davis, the foremost exponent of modern physiographic methods, in a paper ${ }^{a}$ in which he undertook to show that a large proportion of the so-called fresh-water lake deposits in the Rocky Mountain region bear internal evidence of being of fluviatile rather than lacustrine origin-that is, they were spread out by a sort of sheet-flood erosion in moving rather than still waters. Since then 
there has been a strong tendency, especially among the younger disciples of the modern school of physiography, to ascribe a fluviatile origin to deposits that might formerly have been classed as lacustrine, in some cases, as it seems to the writer, without giving sufficient weight to conflicting evidence which appealed less strongly to them as physiographers, or students of surface phenomena, than it would to the general geologist.

In the summer of 1904, under the direction of Prof. R. D. Salisbury, studies of the Pleistocene geology of the Sawatch Range ${ }^{a}$ were carried on by S. R. Capps and E. D. K. Leffingwell, and in the same summer, at the suggestion of Professor Davis, Prof. L. G. Westgate ${ }^{b}$ made a special study of the Twin Lakes glaciated area. In neither case, apparently, was an actual investigation made of the vicinity of Leadville, the conclusions as to the deposits there being probably derived from studies made of their general form from a distance. The conclusions of each of these parties arè confirmatory of those of the writer as to the existence of two glacial epochs in this region; likewise as to the fact that the preglacial channel of the Arkansas River lay west of the present river bed, borings in the placer mines west of Granite having shown that the rock surface beneath the gravel slopes westward for a considerable distance, and that the lowest point is probably midway between Granite and Twin Lakes. The observers first mentioned also consider that the ice of the early glacial epoch must have obstructed the valley, since material that could have come only from Lake Creek Canyon was found by them high up on the slopes of the Mosquito Range, on the opposite side of the valley; but they do not admit "that the dam could have been high enough at any time to hold the water up to the level of the high terraces." They agree, however, with Professor Westgate in holding that these higher terraces are of glacio-fluvial rather than of lacustrine origin, basing their conclusions on the assumed facts that the material of the gravels is mainly coarse bowlders, only slightly or not at all stratified, and that no delta structure is observable in them. According to Westgate, moreover, who came to the region from a study of the Quaternary deposits of the Utah Basin, their surfaces have every appearance of alluvial fans.

While the writer is in general accord with the interpretation given by these geologists to the facts observed by them, he ventures to say that if they had made a careful study of the glacial deposits in the vicinity of Leadville, not on the surface only, but underground, where alone the so-called Lake beds can be seen, they might have been led to a different interpretation of some of the facts. 


\section{LAKE BEDS.}

The data gathered by the writer since the original report was made in regard to these beds are regrettably uneven and incomplete, since in great part they are not the result of perşonal observation but were contributed by those who sunk shafts through the beds, and who, as a rule, not being trained in-geological observation, simply noted the change from coarse and structureless to finer-grained and distinctly bedded material. There was, moreover, no opportunity to obtain an extended section of the beds to determine whether they showed delta or flow-and-plunge structure, since the exposures were limited, as a rule, to the diameter of the shaft, there being no inducement to run drifts through these beds, and, owing to their crumbling nature, the shafts were always promptly lagged up. Their upper and lower limits are also necessarily ill defined, since the bowlders of the overlying Wash, being at considerable depth and in moist condition, are decayed to such an extent that they crumble rapidly on exposure to the air, while the underlying rock surface, when of porphyry, as it is generally, is rotted or decomposed for considerable depth, and shows at many places strong evidence of differential movement, especially in the vicinity of the faulted zones.

\section{COMPOSITION.}

The prevailing material of these beds is of a pinkish-drab color, resembling a fine-grained marl, and seems to be made up of an arkose of decomposed granite or porphyry. This is the general character of the lower part of the beds, which often contain large fragments in a marly matrix, whose position would be readily explainable as having been dropped from floating ice while the marl was still loose and not fully consolidated. In the upper part there is more clayey material, often with alternating beds of sand. It is said that a drill hole on the mesa south of California Gulch passed through 305 feet of Lake beds, including, in the upper half, forty beds of tough clay, from 1 to 8 feet thick, after traversing 48 feet of overlying Wash and 2 feet of sand.

\section{DISTRIBUTION.}

Although the existence of Lake beds beneath the Wash on the lower half of the mesas or terraces that stretch from the hills to the Arkansas Valley has not yet been proved by actual shafts or drill holes, the uniform character of the surface and the fact that borings show that they tend to increase rather than decrease in thickness with distance from the hills favor the assumption that they probably extend down to and perhaps under the present Arkansas Valley as far south as Weston Gulch. 
Their upper limit, as shown by actual exploration, is rather irregular; they are not known to extend into the great gorge of the East Arkansas, nor for any considerable distance up Big and Little Evans gulches. Along the west face of Fryer and Carbonate hills their upper limit is practically the Pendery fault, though in the depression of Stray Horse Gulch they are found a little farther east. On the other hand, a thousand feet higher, in Graham Park, there is a singular potholelike depression filled by them to a maximum depth of 300 feet, as shown by the R. A. M., Rialto, Greenback, and adjoining shafts. The upper level of the former mine, at 390 feet from the surface, is driven for over 100 feet in typical Lake bed material, which there rests on Blue limestone. The rock surface at this point has an elevation of 10,261 feet.

South of California Gulch the upper limit of the main body of Lake beds, which along the face of Carbonate Hill had been trending to the west of south, abruptly bends almost due east and runs parallel to California Gulch, from which it is separated by a ridge of rock that reaches in places within 100 feet of the surface of the mesa, while the bottom of the depression in which the Lake beds have accumulated has been found to be 400 to 600 feet below that surface. This embayment of Lake beds on the ridge known as Rock or Dome Hill was originally supposed to extend only up to about the line of the Iron fault, but recent workings in the Reindeer mine have disclosed, just north of the lateral moraine of the second Iowa Gulch glacier, a channel of Lake beds at an elevation of 10,230 feet, apparently reaching still higher up on the southern edge of the hill. This may connect with a patch of similar material on the northwest slope of Printer Boy Hill, whose extent was disclosed by a drift from the lower Printer Boy mine and by the erosion of Eureka Gulch, but of whose form or extent nothing is definitely known. South of Iowa Gulch the Lake beds extend still higher up on the spur known as Long and Derry Hill, the rock surface beneath them at the Continental shaft having an elevation of 10,750 feet. Still farther south, on the spur south of Empire Gulch, their upper limit apparently approaches yet nearer to the crest of the range, until they end abruptly against the granite on the south side of Union Gulch. Their probable extent in this southern region is given as determined during the original survey, since no new data with regard to them have been obtained outside of the immediate vicinity of the working mines in Leadville, but it is assumed to be fairly correct, since no shaft sunk in areas in which they were indicated on the original maps has failed to disclose them.

It is evident that the rock bottom of these beds in these upper regions stands at an elevation that is too high to admit of its having been covered by the waters of any lake that could have been ponded back in the Arkansas Valley by the damming up of the Lake Creek 
glacier, since these waters can not probably have reached a height above the 9,700 -foot contour. If there had been no elevation of the range since these beds were deposited the only alternative hypothesis would be that they are glacio-fluvial deposits laid down on a gently sloping surface by streams issuing from beneath the melting glaciers, but there is definite evidence of the elevation of the range since that period, and there are other phenomena that are difficult of explanation on the simple glacio-fluvial hypothesis, among them the apparently greater extent of the Lake beds in the bed of the Iowa Glacier than in that of the Evans Glacier. In Evans Gulch their existence has not been noted higher than Cady shaft, opposite Fryer Hill, where the present surface stands at 10,430 feet, while in Iowa Gulch they are found very much farther back than the probable lower end of the glacier, or at points where the present surface is 300 to 400 feet higher. The underlying rock surface, however, stands in an opposite relation, being rather lower on the average under Rock Ridge than in lower Evans Gulch. This condition seems easier of explanation on the hypothesis that the material was deposited along the borders of a lake than simply at the mouth of a retreating glacier.

\section{EVIDENCE OF UPLIFT.}

The evidence of continued uplift of the range since the glacial period is both direct and indirect. The indirect evidence is the sudden deepening of the rock surface to the west of the prominent fault planes, producing an abnormal depression in which the Lake beds are first found. Such a sudden down slope of the rock surface was noticed in the original field work, and it was then thought that it might have been produced by wave cutting along the shores of the old lake, but the evidence accumulated since that time tends to show that it always occurs in the immediate vicinity of fault planes, and it therefore seems more reasonable to attribute it to a gradual movement of elevation along these planes, which may very likely be going on at the present day.

The direct evidence of movement observed by the writer was confined to two places, one in the. Walcott mine, the other in the Elk mine, both of them along the Pendery fault and in the depression of lower Stray Horse Gulch. In each place the rock face on the foot or east wall of the fault, which stands at $65^{\circ}$ or $70^{\circ}$, has been lifted up across the Lake beds, which adjoin it on the west. In the Elk mine the brownish clay that constitutes the Lake beds shows a distinct sheeting parallel to the fault planes, and a selvage of this clay material carries in places a fault breccia that still clings to the limestone foot wall, which it could not have done had this wall constituted a cliff against which the Lake beds were deposited. 
The aggregate amount of such displacements can not be accurately determined. In the Elk mine it is certainly as much as 100 feet, and possibly 150 feet. It is probably nearly as much in the Walcott mine, but no Lake beds have yet been found east of the fault in that mine. The amount of difference to be accounted for is, however, less than the present surface would indicate. For instance, the rock surface on the north-south line of Section XII (Pl. VII), a short distance west of the Pendery fault, is not more than 200 feet lower than that at the same distance west of the Dome fault, which is about a mile farther east, while the relative difference of level in the present surface is over 500 feet. On the other hand, the slope of the rock surface may steepen west of this line, to judge from the data gathered on the spur or mesa next south of California Gulch. On this spur shafts and drill holes have reached the contact below the Lake beds at somewhat irregular intervals in an east-west direction for a distance of about 8,000 feet. The angle of the rock slope in this distance, if calculated from its depth at the extreme points, would be $5^{\circ}$, or nearly double that of the present surface, but from a study of the data furnished by those who carried on these underground explorations it would appear that this slope is very irregular. Below the Dome fault it drops abruptly 200 to 300 feet. At the Iron fault it has a comparatively slight drop, and from there to the Revenue shaft, a distance of about 3,000 feet, the figures obtained show no general lowering of the rock surface. Thence westward to the drill hole on the Mike claim, a distance of about three-fourths of a mile, its descent is more rapid, and if continued at the same angle would make the rock surface at Malta 300 feet below the present valley level. It must be admitted, however, that the basis for these determinations is rather uncertain, for the accounts show that beneath the well-defined Lake beds there is a considerable mass of broken rock, which in some places aggregates 100 feet or more in thickness, and renders it difficult to determine the exact depth at which rock in place was actually reached. While the data are therefore evidently yet too incomplete to enable the geologist to reconstruct with any considerable degree of accuracy the rock surface beneath the deposits of the first glacial epoch, it seems reasonably certain that it has been somewhat disturbed by uplift since that time.

\section{ORIGIN.}

As to the manner of formation of the Wash and Lake beds-names which have been retained in deference to established local usage-although it is admitted that the mesa Wash is of probable glaciofluvial origin, until more conclusive proofs to the contrary are obtained the writer is inclined to the belief that the fine-grained, stratified

Bull. $320-07-2$ 
material, to which the original report gave the name Lake beds, must have been, in part, at least, laid down under water-possibly in great measure as broad delta deposits--hence that a lake actually existed' in the upper Arkansas Valley toward the close of the first glacial epoch. Some part of the higher-lying beds may have been deposited in local ponds or lakes close to points where this finer material was issuing from beneath the glaciers. It is probable that all these lakes were of relatively short duration, and that, when the floods came that accompanied the retreat and more rapid melting of the glacial ice, their barriers were quickly cut through and the lakes drained while the overwash was being carried down and spread out over the surface of the already deposited Lake beds. In narrower parts of the glacial channels doubtless these were in measure eroded away, and such erosion may account for the apparent want of connection between parts of the lower- and higher-level Lake beds at the present day.

\section{SLOPE OF ROCK SURFACE.}

As to the slope of the rock surface beneath the Lake beds, it seems probable that its westerly inclination may generally be slightly greater than that of the present surface, as far west, at any rate, as the Paleozoic beds are likely to extend; but that toward the bottom land of the present Arkansas Valley, where granite and gneiss would constitute the bed rock, its slope may decrease rapidly and soon become nearly level, except for its southerly inclination down the Arkansas Valley.

It is probable that a southerly inclination of the rock surface exists in the mesa region also, which should be added to the westerly inclination, for it appears to stand 100 to 200 feet above the 10,000-foot contour, where Evans Gulch bends northward into the East Arkansas Valley, whereas on the banks of California Gulch, in the Maple Street shaft, it is said to be over 500 feet lower. As the surface was probably furrowed to a certain extent by the older glaciers, or by the streams that issued from beneath them, it may be well to consider the probable course of these glaciers as far as it can be determined from the evidence at hand.

\section{POSITION OF THE MOSQUITO GLACIERS.}

The amount of erosion that has gone on since the glacial period has been so great that it is not easy to differentiate in the detrital materials found near their present surface those that belong to the first from those that belong to the second glacial epoch, or from those that are postglacial. We get some conception of the amount of this erosion when we consider that the deep cutting of California Gulch is postglacial. Only those gulches that head in glacial cirques or amphitheaters could have carried large glaciers. These were the East 
Arkansas, Evans, Iowa, and Empire gulches. The first, though much longer and consequently carrying a larger glacier than either of the others, may be left out of consideration in the present discussion, since there is no evidence that its deposits had much influence on the area here discussed.

The courses of the later glaciers in Evans and Iowa gulches, as quite clearly defined by the lateral moraines which still stand in rather definite ridges, were remarkably straight after leaving the amphitheaters in which they took their rise, in marked contrast with the zigzag course of California Gulch. In Evans Gulch the amount of morainic material deposited along the sides of the glacier was so great that, as the ice melted, new stream beds were formed along the outer edge of these new accumulations of gravel, now known as Little Evans and Stray Horse gulches, which head in basinlike depressions known as Prospect Mountain amphitheater and Adelaide Park, respectively. There is some evidence that in its lower part, after leaving the confining slopes of Prospect Mountain and Breece Hill, the ice spread out somewhat, so as to cover Fryer Hill, but if it extended down as low as the gravel ridge known as Capitol Hill, it was probably bounded by that on the one side and by James Ridge on the other, and did not bend into the East Arkansas Valley as does the present postglacial stream.

The Iowa Gulch moraines extend straight down over the Lake bed deposits for a mile or two below the last confining gorge between Long and Derry and Printer Boy hills, but show no evidence that the ice sheet widened below to any considerable extent. The Empire Gulch glacier has left similar indications with regard to its lower course, but in its upper part followed a more irregular course.

We must assume that the earlier glaciers in their upper courses, where they filled channels bounded by rock slopes, must have followed the same course as did the later glaciers. To judge from the amount of material they left behind they would appear to have been more extensive than the later" glaciers, but we can not now distinguish their lateral moraines. It is probable that the earlier Evans Glacier entirely overrode Yankee and Fryer hills and that in its lower course a part, possibly the greater part, flowed down the depression of lower Stray Horse Gulch, between Carbonate and Capitol hills, since the evidence gathered during the preparation of the present map shows a depression in the rock surface under this part, as indicated in the sections. Whether the eroding agent was ice or water, its channel, on leaving the steeper hill slope, evidently bent to the southwest, running about parallel to a line drawn between the Sixth Street and Cloud City shafts. Along this channel relatively less of the Paleozoic beds would be left than on either side, and to this extent more ore-bearing 
rock material would have been removed, but the channel was probably so shallow that the amount thus carried away would not have been sufficiently large to influence essentially the prospective value of the ground.

\section{ECONOMIC DEVELOPMENT.}

Before proceeding to the description of the present geological structure of the Downtown area, it may be well to review briefly the progress of knowledge with regard to it as illustrated by the successive mining developments within the area. The reader's understanding of this review will be much facilitated by frequent reference to the map and sections. The area covered by the map is approximately 1 mile in length by two-thirds of a mile in width, the longer dimension being from north to south. The western limit runs diagonally across. Harrison avenue, from a point just north of its junction with Chestnut street northward to the southwest corner of East Thirteenth and Hemlock streets, while the eastern boundary runs from the top of the western slope of Carbonate Hill to the southwest point of Fryer Hill. The map thus includes practically all of the town east of Harrison avenue and south of the Denver and Rio Grande Railroad station.

At the close of Survey field work in the summer of 1881 underground exploration was practically confined to a zone about 1,000 feet wide along the eastern or upper edge of the area mapped, and the structure, as deduced from these explorations, was determined as follows:

At the northern end of this zone, on the west point of Fryer Hill, White porphyry was found both above and below the Blue limestone, or the vein material which replaced it, this being within the northwestsoutheast belt along which the White porphyry sheet cuts diagonally across the Blue limestone, thus splitting it into two or more wedgeshaped bodies. Furthermore, a sheet of younger Gray porphyry cut across both, and at some places assumed a dikelike form. This whole series of formations was found to rise gently westward toward the west point of Fryer Hill. White porphyry had been found under the Wash to the west of this, and it was assumed that it represented a western dip in the formations beyond an anticlinal fold.

In the depression forming the two Stray Horse gulches, between Fryer and Carbonate hills, the few shafts that had been sunk furnished but little definite information with regard to the structure, beyond the indication that it is very irregular and broken. In both these gulches the rock surface is buried beneath 50 to 100 feet of Wash. On Carbonate Hill, however, the rock formations, which were covered by only from 6 to 10 feet of rock slide, were found to be quite regular, striking a little east of north and dipping southeast- 
ward at angles of $12^{\circ}$ to $20^{\circ}$. The normal series here represented is given in the following table, in descending order:

\begin{tabular}{|c|c|c|c|}
\hline Local name. & Geological age. & Character of rocks. & $\begin{array}{c}\text { Average } \\
\text { thickness. }\end{array}$ \\
\hline White porphyry. & Pre-Cretaceous & White rhyolite porphyry. & Feet. \\
\hline Blue limestone ...... & Lower Carboniferous. & Blue-gray dolomite... & 200 \\
\hline Gray porphyry. & Pre-Cretaceous.............. & Gray monzonite porphyry.. & 50 \\
\hline Parting quartzite... & Devonian............. & Coarse quartzite... & 30 \\
\hline White limestone.... . & Silurian............ & Drab siliceous dolomitic & 160 \\
\hline Lower quartzite. & 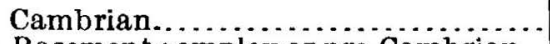 & Mostly white quartzite.... & 160 \\
\hline Granite......... & Basement complex or pre-Cambrian.. & Granite and gneiss........ & $\ldots .$. \\
\hline
\end{tabular}

Of these the igneous rocks are necessarily the more liable to vary, both in horizon and in thickness. The Gray porphyry is generally in a single sheet, in the body of the Blue limestone, but may occur in more than one sheet, and be found anywhere from the top to the bottom of this formation. Erosion has removed more or less of the White porphyry, which is consequently at its greatest thickness at the eastern limit of the fault block, and farther west has been thinned by erosion until, along the base of the hill, the Blue limestone is exposed beneath the thin covering of porphyry slide. It was in following this limestone eastward on the dip that the Carbonate Hill mines found their great bodies of carbonate of lead and chloride of silver in a matrix of impure iron and manganese oxide, resulting from the oxidation of pyritous ores. West of the line of the Carbonate fault the surface is generally occupied by White porphyry, over which is a covering of Wash that thickens rapidly with increasing distance from the steeper slope of the hill. From information derived from the few shafts already sunk in this zone it was inferred that toward the west the formations descend either in a general westward slope or in a series of sharp folds and faults, and that, as the ore body disclosed on Carbonate Hill might reasonably be expected to extend in that direction, the region was well worthy of exploration. ${ }^{a}$

As regards the best method of developing this area, it was foreseen that under the deepening Wash an enormous amount of water, draining from the adjoining hill slopes, would necessarily be found, and the suggestion was offered that a combination of property owners be formed to sink one or more deep shafts well out on the mesa slope, which would not only determine the general slope and character of the underlying rocks but would drain the intermediate ground, and thus facilitate mining over the whole area. If this were found impracticable, the next best plan, it was suggested, would be to sink shafts on the lower slope of Carbonate Hill and gradually follow the contact westward. The latter plan is the one that has practically been followed, but the consequent development of the region has proceeded much more slowly than it would have under the first plan, 
for, as explained in the first report, each fault block as a rule constitutes a separate hydrostatic basin, within the limits of which there is so free a circulation of underground waters that the rise or fall of the ground-water level in one mine is sympathetically felt in all the others within the block or basin. Thus, as each new shaft to the westward reached the ore horizon (as a rule at a deeper level than the previous ones), it was found that it drained the water from all the surrounding but higher-lying levels, and the enterprise was penalized with an undue proportion of the very serious expense of pumping water. This was later remedied by the association of the important mine owners on the community of interest principle, by which it was arranged that each should bear his proportionate part of the total expense of pumping. Even then, however, men who desired to explore still lower ground sometimes found it difficult to gain admission to the pumping association, and thus were prevented from sinking below the level reached by the mines already working, unless they were willing to pump for the entire region.

- The sinking of a 500-foot shaft to reach a horizon in which there was only a possibility of finding ore was already a sufficiently hazardous enterprise, but when the search for ore was limited to a given level, and the seeking for it below that level involved such an enormous additional expense, it can be readily conceived that the risk was almost prohibitory.

It is not possible to give the exact order of development of the various mines of the Downtown area, as the writer's visits were made at irregular intervals, between which it sometimes happened that a mine had been opened, worked out, and closed; in many cases, however, to be reopened later. Among the earlier mines was the Pocahontas. whose shaft traversed about 100 feet of Wash and about 180 feet of White porphyry before reaching the Blue limestone. Its ore was found on various shelves of the fault zone, the shaft having reached the limestone near the Pendery fault. The Gray Eagle followerl closely, also working ore along the upper contact in the fault zone.

- Next, the group of the Dillon, Elk, and Hussey mines found second contact ore between Gray porphyry and Parting quartzite within about 200 feet of the surface, but this ore was sharply cut off on the west by the Pendery fault, and the mines were in time closed down without getting ore at lower levels. The Walcott and Hibschle mines, a little farther northwest, found ore at the same general depth, also immediately under the Wash, but this ore, owing to the general rise of the formations toward the north, was at a lower geological horizon, namely, near the bottom of the White limestone and in the Transition beds at the top of the Cambrian.

South of the Pocahontas, on the same general level, the Weldon and Glass-Pendery shafts were sunk through Wash and White porphyr! and cut the Pendery fault. 
By these explorations the general position of the fault zone was fairly well defined and shown to be considerably west of the Carbonate fault, as located on the early maps, but the depth of the limestones farther west was still uncertain until the Sixth Street shaft was sunk within the streets of the city, about 1,000 feet west of the Pendery fault.

The location of this shaft was unfortunately chosen in that it found the rock surface in the depression that follows the general course of Stray Horse Gulch, consequently abnormally deep. It thus drained the water from all the region around, which entered in such volume that for a long time it could not be handled, and the mining of the fine ore bodies that were afterwards found in its neighborhood was delayed for a number of years. It established the fact, however, that the Blue limestone was still uneroded at that distance to the west, though its elevation was but little below that at the base of the Pendery fault.

The next pioneer shafts were the Bon Air and Bohn, sunk a little farther west and considerably south of the Sixth Street shaft. They found the rock surface over 1,000 feet higher, but the limestone contact a little lower. It was thus proved that the latter lies fairly flat in a broad shelf to the west of the Pendery fault, and it has been on this shelf that the mining of the last decade has been mainly conducted, while in a general way the work has progressed eastward toward the faults rather than in the opposite direction. Thus, at the south the opening up of the Weldon No. 2, Midland, and Can mines has followed that of the Bon Air and Bohn; at the north the developments in the Coronado and Capitol have been the result of the sinking of the Sixth Street shaft; while in the central region the Penrose, the first shaft sunk there, has been followed by the Midas, Bison, and Starr to the east and south. •

The next step westward was made by the Cloud City shaft, which was sunk in the midst of the city blocks and which, after passing through 425 feet of Wash and Lake beds and a few feet of White porphyry, came into the westernmost fault yet discovered, which has been called the Cloud City fault. Here again the water has been an obstacle to rapid development, for the Cloud City shaft was sunk near the eastern houndary of the company's property; therefore, to develop the main area, it was necessary to sink the shaft deeper by the amount of the throw of the fault. This was, however, impracticable, until the owners gained admission to the pumping association, which for some years was refused them.

\section{PRESENT CONDITIONS.}

As the geological indications given on the accompanying maps and sections are entirely dependent on data derived from mine workings, it may be well to state in some detail the condition of these workings 
at the time the last observations were made, namely, in the summer of 1905 , since subsequent derelopments may furnish ground for modification of the conclusions reached, and no one understands better than those who have carried on this work the great uncertainty that attends the determination of probable structure in a region like this, in ground that has not already been opened and examined. The general order followed in making this statement will be from the east westward, the areas along the eastern border of the map being first considered.

Carbonate Hill. - Of the southeast corner of the area-that is, Carbonate Hill east of the Carbonate fault-but little knowledge has been gained by actual observation since the original survey, as most of the large mines were closed down when the periodical visits were made, and the working maps of but few of them were available for study. In later years work in this area has been done mostly by leasers who do not keep up regular surveys, and the data obtained are oral, and hence somewhat vague and uncertain. The structure in this area is, however, relatively regular, and in spite of this uncertainty the formation outlines should be fairly accurate. Of the distribution of ore bodies, on the other hand, so little is accurately known that their representation may be considered to be only a rough approximation.

Fryer Hill.- On Fryer Hill, a portion of which is represented on the northeast corner of the map, there are the same grounds of uncertainty as on Carbonate Hill, and the structure is not simple but extremelr. complicated, owing to many irregular intrusions of both Gray and White porphyry. No underground examinations were made in this area, and the only new information furnished is with regard to the rocks passed through by a few new shafts, such as the Clark and Colorado Chief No. 2.

Stray Horse Gulch.-Between Fryer and Carbonate Hills lies an area concerning whose structure there is still greater uncertainty, for it is a region where both intrusive porphyries apparently cut across the sedimentary strata instead of conforming with their bedding, and on this account the indications on the earlier map were confessedly tentatire. Of the mining that has been done in later times few reliable records have been obtained, the complications of structure having evidently been a serious drawback to the operations there carried on. The indications in this region must therefore be regarded as merely showing a possible solution of the theoretical conditions assumed.

Below Carbonate fault. - With regard to the belt of ground immediately below the Carbonate fault, and thus within what is here called the fault zone, there is also some uncertainty, since the mine openings there were made in the intermediate period between visits, and man! of the facts with regard to them have been obtained orally rather than by personal observation. This applies to such workings as the Jolly, Buckeye Belle, Forsaken, and those on the lower part of the Waterloo, 
Morning Star, Evening Star, Crescent, and Catalpa claims. In this region of complicated faulting the data obtained have furnished a series of structural problems which the added uncertainty as to correct location of some of the abandoned shafts has rendered it very difficult to unravel. While the solutions presented by the map and sections are thus subject to possible errors of detail, it is believed that these will not affect the correctness of the general conclusions arrived at.

Southwest slope of.Carbonate Hill.-The steeper slope of the southern end of Carbonate Hill made by the cutting of California Gulch, not being covered by Wash, is considered as an area of outcrop. In point of fact, however, this surface is actually covered by rock slide to such a depth that only where artificial cuttings have been made can the character of the underlying rock be determined. Such openings are irregularly distributed, and the few that had been driven to any considerable depths were wholly inaccessible, so that while there is an appearance of duplication of outcrops, which suggests a fault, in the absence of such direct proof of its existence as would be shown by its crossing by a drift, none has been indicated.

Bench below Pendery fault.-For a thousand feet or more west of the Pendery fault the upper surface of the Blue limestone, except where it is upturned against the fault plane, stands at an elevation between 9,750 and 9,850 feet, so that, neglecting its minor undulations, it may be considered as a broad bench broken on the west, and through part of its length, by the Cloud City fault. It is on this bench that most of the mining of the last decade has been carried on, and from the workings of these mines have been derived most of the facts of personal observation on which the present report is based. These include, commencing, at the north, the workings of the Capitol, or Northern, Coronado, Sixth Street, Midas, Bison, Gray Eagle, Penrose, Starr, Bohn, Bon Air, P. O. S., Midland, and Can shafts, which constitute a horizontal area of about 100 acres of almost continuously explored ground.

Outside area.-Outside of these connected workings the data as to underground structure have been derived from disconnected workings or isolated shafts of which only a small number could be personally examined. ${ }^{a}$

On the. north the limestone contact has been reached by the Newell (P), Villa, and Delante No. 2 shafts within the area of the map, and the Delante No. 1, Seeley (P), Jason, Neptune, All Right No. 2 (P), Fairview No. 4 (P), Stumpf, and Hofer shafts on Poverty Flat, beyond that area; on the west in the Cloud City (P), Home Extension and A. V. (P) shafts; on the south along California Gulch in the Toledo Avenue (P), California Gulch, Valentine, and Maple 
Street shafts. The latter, on the north bank of California Gulch, between James and Maple streets, is the westernmost point at which the depth of the limestone contact had been reliably determined, being about 2,100 feet west of the western edge of the area mapped. A little farther south a drill hole sunk on the Mike claim is said to have reached the contact, but the record of rock material passed through is somewhat puzzling and difficult to construe.

\section{STRUCTURAL GEOLOGY.}

The following verbal description is intended to supplement the information given by the accompanying maps and sections, so as to enable the reader to fill the gaps left between sections and to appreciate the relative proportion of known facts and of inductive reasoning which form their basis in different parts of the area. He should keep before his mind the fact that the surface maps represent the actual rock surface from which it is assumed that the detrital covering of Wash and Lake beds has been removed. The position and approximate thickness of this covering is given on the sections. In this verbal description the faults will be described first and afterwards the successive cross sections and different mines, or groups of mines.

\section{FAULTS.}

In describing the effect of faulting on a series of beds, as deduced from the relative position in which they are now found, more than one term may be used to express the amount and character of the movement. The throw is, properly speaking, the maximum amount of movement along the plane of the fault. Such a throw may be resolved into three factors or components:

(1) A vertical component, which is the vertical distance a given point has been raised above its original position, and which is called the vertical separation.

(2) A horizontal component, which is the horizontal distance that such a point has been moved along the plane of the fault and which is called the lateral separation or offset.

(3) The angle which the plane of the fault makes with the horizon and which is called its dip.

Of these the offset can rarely be determined, though it is often evident, from the indication of the striæ on the walls of the fault, that the movement was not strictly vertical, and that, hence, there must have been a lateral component. For practical purposes, in the present case, the vertical component and the dip, as given by sections along a vertical plane, such as those here presented, furnish the essential facts. On such sections the amount of throw represented with a given vertical separation is dependent on the angle of 
dip of the fault, being equal to the vertical separation if the fault plane is vertical, but increasing as its angle of dip departs from the vertical. On the other hand, with a given angle of dip the vertical separation naturally increases with the throw. The angle of dip in the normal faults in this region is observed to vary from point to point, but as observations on the actual fault planes are generally confined to one or two points the rest of the fault must be drawn at an arbitrary angle, which is here assumed to be about $65^{\circ}$, the one most commonly observed. In some cases the angle of dip has been found to shallow somewhat with depth. Such shallowing is not sufficiently uniform to justify its assumption as a general rule. On the other hand, the vertical separation, being dependent on the relative position of certain given rock formations in the mine drift on either side of the fault, can be determined with considerable accuracy for the sedimentary beds, though the position of the intrusive sheets of Gray porphyry is more uncertain, as they are liable to change in geological horizon within comparatively short distances. Hence, on the sections the representation of vertical separation is generally a closer approximation to the truth than that of the amount of throw.

Where the fault is distributed on several planes the amount of displacement on a given plane is necessarily less than when the total movement is on a single fault plane. For the whole fault zone the vertical separation varies from 600 to 1,000 feet, but, as will be observed, the amount of throw on the same fault has a much wider range of variation:

The faults have been represented by a single line on the sections for the reason that, though the amount of fault material involved in their movement may in some cases reach a thickness of 50 feet or more, it varies very much with the amount of throw, the character of rock passed through, etc., and is sometimes less than the thickness represented by a line on the scale of these sections.

Pendery fault.-The Pendery is the important fault of the area, since it is traceable continuously across its entire extent and probably extends for considerable distances beyond it in either direction, thus constituting one of the great faults of the region. Its throw at either end, where it is a single fault, is 1,000 to 1,200 feet, as determined by the sections, which is probably a maximum. Between the Can and Walcott No. 2 shafts the throw indicated on the Pendery fault is very variable, because its movement is distributed on a number of minor fault planes. The number of these minor faults is greatest in the vicinity of the parallel $39^{\circ} 16^{\prime}$, where, as may be observed, the outcrop of the Pendery fault has a marked reentering curve to the west.

In such a reentering curve on the Iron fault the throw is also found to be distributed on a number of minor fault planes or step faults. 
In the case of the Pendery fault a possible reason for the reentering in the outcrop may be found, however, in the probable preexistence of an earlier monoclinal fold, with sharp drop toward the south, which is known to run in a general east-west direction through the northern end of Carbonate Hill, just north of the Wolftone, Maid, Seneca, and Harker shafts, and which, as will be explained later, had an important influence on ore deposition.

Carbonate fault. - This fault may be considered as one of the minor faults of the Pendery fault zone. Between the Carbonate and Etna mines it has a throw of 250 to 300 feet, but the amount of throw decreases toward the north to such an extent that it can not be traced continuously. What is assumed to be its continuation was found at about 175 feet west of the Harker shaft, where its movement is reversed, its downthrow being eastward and its displacement not over 50 feet. Beyond that it has not been proved, and it is doubtful if it extends much farther as a continuous plane of movement, though other small faults are known to exist in the Stray Horse Gulch depression. To the south it is represented as connecting with the Pendery fault by a sharp bend westward. It has not been actually proved to have this bend, which is assumed as the most probable solution of the facts observed in the adjoining mines. It is possible that it continues more directly south and gradually dies out. Faults of small throw are likely to have a limited longitudinal extent, and it is probable that there are other faults of small throw in the region to the south on which such movement has been distributed. One such fault of about 150 feet throw has been cut just east of the Toledo Avenue shaft, in California Gulch, which can not be surely connected with any other, though it seems probable that it may be the same one struck by the Revenue shaft on the mesa south of California Gulch. Small faults of less than 100 feet throw were also found in the Modoc and Thespian ground, under the top of Carbonate Hill.

Niles fault. - The Niles fault, so named because it was best shown in a drift from the Niles shaft, is intermediate between the Carbonate and Pendery faults. Toward the north it was cut in the Buckeye Belle and Jolly workings, but has not been proved farther north, where it probably passes into a slight fold. Its supposed continuation southward passes into the St. Mary, Washburn, and upper Weldon ground. That it actually connects with the Pendery fault, as indicated on the map, is not proved.

Wildcat faults.-Curving faults in the Wildcat ground, indicated on the map as connecting, respectively, the Carbonate, Niles, and the Pendery faults, have not been determined by actual observation, as they are in ground which was inaccessible at time of visit. They are given as the most probable explanation of the relative position of the different formations as deduced from verbal information. 
Bison fault.-The Bison fault, indicated on the map, is shown only in the workings of the Bison mine. Its indicated connection at either end with the Pendery fault is assumed, not observed. It has a normal westerly dip and is cut by the shaft and also by the drifts of the mine to the west of the shaft. There is another fault shown by these workings that has a reversed or easterly dip, so that the wedgeshaped block of ground included between this and the Pendery fault has dropped instead of being uplifted. It is indicated as a cross fault between the Bison and Pendery fault. All the complications of structure disclosed by the workings of the Bison mine could not be indicated on the present scale of drawing, nor were the workings themselves sufficiently extensive at time of visit to admit of their being fully worked out and explained.

Weldon fault.-The Weldon fault, so named because its movement apparently reaches a maximum in the Weldon mine, is of a rather common type, and may be called a monoclinal fold fault, since it belongs to a class of faults that usually pass into a monoclinal fold at either end. They are generally of small throw-in this case not over 100 feet-and stand at rather steeper angles than the normal faults; hence if they extend far enough in depth they will probably join the main fault, as is shown in Section X (Pl. VI). This is, however, a theoretical deduction not proved by actual observation, and it is possible that their vertical extent is as limited as the horizontal has proved to be; hence, in the sections, many of these faults have not been continued up to the rock surface. South of the Weldon mine the Weldon fault has been observed in the Midland and P. O. S. ground with very much diminished throw. Farther north it was seen in the Pendery, Gray Eagle, and Bison areas, but whether it extends to a connection with the Pendery fault in the Midas ground was not determined. Other fold faults of comparatively small extent have been observed which are not indicated on the surface map, and some of these do not cross the plane of section. In these the throw is but slight and the fold is not traceable for any considerable longitudinal extent.

Cloud City fault.-This fault is clearly shown in the Cloud City shaft, where it has two and possibly three planes of movement within a horizontal width of about 50 feet. The workings disclose a westward dip of the contact west of the fault, but the amount of its throw had not yet been proved. Its southward extent is probably very limited. Toward the north, it is assumed, it connects with the fault that passes through the Sixth Street-Coronado ground, though this connection has not been proved. In the lower workings of the Coronado it appears to split, one branch going north toward the synclinal fold in the Capitol ground; the other bending eastward and probably passing into a fold in like manner. It is noticeable that the 
continuation of the latter line up Little Stray Horse Gulch marks a rise in the beds toward the north. It seems improbable that any considerable faulting of the beds will be found west of the Cloud City fault, though some small fold faults probably occur. In view of its limited longitudinal extent and small throw, which is probably nowhere much over 200 feet, the Cloud City may be classed as a fold fault.

\section{GRAY PORPHYRY SHEETS.}

The sedimentary formations are comparatively uniform in thickness and always retain the same relative position, so that if the depth of the top or bottom of one of these is known one can calculate with a fair degree of accuracy that of the others beneath the uniform covering of White porphyry. One can never know beforehand, however, exactly where the Gray porphyry sheets are to be found; yet in the search for ore it is extremely important to locate them, for experience has shown that in their vicinity important ore bodies, generally known as second-contact bodies, are liable to occur. The only available guide in searching for them in unexplored ground is the knowledge of the position they occupy in ground that has already been opened. The most common position of the Gray porphyry intrusion, when it is a single sheet, is about the middle of the Blue limestone, and its average thickness may be taken at about 50 feet. This is the position given it in those parts of the sections where there is no ground furnished, either by actually observed data or by inference, for placing it elsewhere. Its most pronounced departure from this average position is in the middle ground, in the vicinity of Penrose and Midas shafts, where it rises in places to the top of the Blue limestone, and at several points apparently splits, sending off shoots at lower horizons, since two or more distinct sheets are found at certain points. Section XII (Pl. VII) gives the most comprehensive view of the general distribution of the Gray porphyry sheets, from which it is seen that from near the Lazy Bill shaft northward to the line of the Sixth Street shaft it is near or actually in contact with the overlying White porphyry, and that within this extent there are several small sheets at some distance below it. North and south of this area it descends in horizon quite abruptly in the Sixth Street-Coronado ground, and more gradually toward the south, through the Weldon, Bon Air, and Bohn claims. Near the latter shaft there is another vertical body, which is assumed to be an offshoot from the main sheet, though its actual junction with it could not be seen. To the east of the Penrose shaft the main sheet descends in horizon somewhat abruptly in places, and in the Bison ground it apparently forms two sheets, though, owing to the extremely complicated faulting in this ground, one can not be sure of the original position of the different 
beds. Farther northeast, beyond the Pendery fault, in the ElkHussey ground, it lies a comparatively short distance above the quartzite. Still farther east, in the Stray Horse Gulch depression, it cuts across the other beds, at some places in such thickness that the possibility is suggested that there may be a vent in that region through which it has come up through the underlying Archean. Farther north, in the Poverty Flat region, and farther west, beyond the Cloud City fault, it has not yet been cut by any shafts or drill holes, and although this is not absolute proof of its nonexistence, it has been indicated on the respective sections as wedging out, since they are drawn on the principle of indicating only those features of whose existence there is some positive evidence, either direct or indirect. Thus on Section XI (Pl. VII), midway in its extension beyond the limits of the map, the Valentine shaft found 45 feet of Gray porphyry between White porphyry and Blue limestone, while the Maple Street shaft, at the western extremity of the section, went 135 feet into Blue limestone without cutting any Gray porphyry. On this ground the Gray porphyry sheet is represented as wedging out midway between the two shafts.

There is as yet no absolute evidence of Gray porphyry sheets below the Parting quartzite in this area except on Fryer Hill, in the Colorado Chief No. 2 shaft. On the original map a sheet was indicated in Silurian limestone at its crossing of California Gulch on the evidence of material supposed to come from a couple of small shafts in that neighborhood, but it is now thought that there was some error in the location of these shafts or in the determination of their horizon and that there is no sufficient reason for supposing that such a sheet exists. Although comparatively few drill holes have been sunk to the underlying granite west of the Pendery fault, and the evidence is therefore negative for a considerable part of the area, it is probable that there is no general Gray porphyry sheet in these lower horizons.

\section{ORES OF THE DISTRICT.}

\section{GENERAL CONDITIONS.}

As these ores, so far as developed when the present examination was made, have practically the same mineralogical composition as those which were fully described in the original report, no special study of them has been attempted during the various visits to the district made for the purposes of this revision. Indeed, all the time that could be devoted to underground work in each case was taken up in searching for facts bearing on geological structure and on the genesis of the ore bodies.

Up to the time of the last visit the developed ore bodies lay entirely within the oxidized zone and were all found at horizons above the 
Parting quartzite except a few bodies at lower horizons that, being laid bare by the scoring off of the overlying beds in the Stray Horse Gulch valley depression, were found immediately below the Wash. The existence of sulphide ores in the White limestone just east of the Cloud City fault in the Penrose, Sixth Street, and Coronado grounds had been determined by a series of diamond-drill borings from the 600 -foot levels, but these ores had not yet been reached by mine drifts. From their analogy with other sulphide ores of the district, it may be assumed that these consisted originally of diversely shaped masses of pyrite and marcasite, with a varying admixture of zinc blende and galena jrregularly distributed through their mass and at some places following rather ill-defined lines.

\section{METHOD OF OXIDATION.}

The process of oxidation, being carried on through the agency of waters coming from the surface, acts primarily on the upper surface of the sulphide body, but when the latter is exceptionally dense and of considerable size the oxidation may proceed from the sides and even from the under surface inward before the center of the mass is completely altered. The first step in the process is its gradual disintegration into a sand of loose crystalline grains, the faces of the crystals becoming more and more pitted as the process advances. The metallic sulphides first become sulphates and gradually suffer further changes until they reach a stable form. . During these changes there must have been a certain amount of transmigration of materials involved, which tended to enlarge the area occupied by the ore bodies, though, as a certain part of the altered matter must have been entirely carried away, the actual weight of the oxidized ore is probably less than that of the original sulphide.

Iron.-The first product of the alteration of the iron sulphides is the hydrous sulphate, melanterite, or iron vitriol, which can be seen in some places among the partly altered grains of pyrite. This is, however, an extremely unstable compound and may change to a basio ferric sulphate, which is apt to settle near the base of the ore body in the form of an ocherous yellow clay, carrying considerable silver, lead sulphate, and other minerals. In greater part, however, it becomes the hydrous oxide-limonite-which penetrates and replaces the surrounding limestone and with a varying admixture of other materials, principally silica and manganese dioxide, forms the low: grade ore, or vein material, locally known as iron.

Zinc.-The hydrous zinc sulphate is presumably more soluble and less stable than the corresponding iron sulphate. In Leadville, like the gypsum, which should have been formed by the reaction between iron sulphate and limestone, it is practically absent from the oxidized zone and must have been carried away in solution or redeposited as * 
sulphide below the zone of oxidation. It has, in fact, been observed that the sulphide ores are much richer in zinc blende immediately below the limit of oxidation than elsewhere. Dechenite, or the vanadite of lead and zinc, is also found as an accessory and rather rare mineral.

Lead.-Lead minerals being less soluble than those of the other metals, many unaltered kernels of the sulphide, galena, are found in the midst of oxidized ore bodies. Around such kernels the normal process of alteration through the sulphate, anglesite, to the carbonate, cerussite, can generally be observed, but throughout the mass of the oxidized ores the predominant lead mineral is cerussite, in which no anglesite is observed. Pyromorphite, the chlorophosphate of lead, is occasionally found in the richer bodies.

Two general forms of lead carbonate ore are recognized by the miners as "sand carbonate" and "hard carbonate.". The former are aggregations of imperfectly crystalline granules of cerussite, the largest bodies of which are as a rule found immediately under or near the porphyry contact. They are composed of remarkably pure carbonate of lead, some of them white, but most of them somewhat stained by metallic oxides, and are evidently the product of the alteration in place of considerable bodies of galena. The hard carbonate is a jasperoid, or siliceous replacement, impregnated with cerussite, in which the latter may have been slightly transposed during alteration. It is irregularly distributed through the mass of iron vein material, but is especially abundant around large bodies of sand carbonate. As a rule, the sand carbonates contain the smallest amount of silver in-proportion to the lead present-say, 20 to 40 ounces of silver in ores that run 50 to 70 per cent of lead; whereas the hard carbonates generally carry about an ounce of silver to each unit of lead.

The galena in the oxidized ores is exceptionally rich, often running several hundred ounces to the ton, which is apparently due to secondary enrichment.

Silver.-The amount of silver in the original sulphide ore is so small that its presence can not be detected by the eye. It is probablv in the form of sulphide, but whether mechanically mixed with the other sulphide or in actual combination has not been determined. From the few analyses available it would appear to be more abundant in the zinc blende and galena than in the pyrite, though it is very generally present in the latter. In the unaltered and enriched ores, while galena and zinc blende may carry 50 or more ounces per ton, the pyrite would not be expected to assay more than 10 ounces.

In the oxidized ores, probably owing to the ready solubility of its sulphate, silver seems to have been the most generally transposed Bull. 320-07-3 
metal next to zinc, for it is universally present in small amounts in all vein material, and the country rock around the ore body is often impregnated to a slight extent. Its stable and visible form is the chloride, which, in the Leadville ores, usually has a slightly greenish color and contains a small amount of bromine and iodine. It usually lines cracks or joints in the other minerals, but is in places concen. trated in small bodies, in some of which a crystalline structure is distinguishable.

Native silver is occasionally found in the richer ore bodies, especially at the upper contact. In general distribution the tenor in silver in the oxidized ores diminishes with depth. The upper-contact bodies as a whole are the richest in silver, the second-contact bodies having on the average a slightly lower tenor, while at lower horizons the ore is of distinctly low grade. Under favorable conditions exceptionally rich concentrations may be found at either horizon, but these are more common at the upper contact than elsewhere.

Gold.-The small amount of gold found, which in the ores in this part of the district rarely reaches more than a few hundredths of an ounce per ton, is intimately associated with the silver. In some parts of the district traces of telluride have been found, which would suggest a combination with that metal, but nothing can be definitely determined with regard to the constitution of a metal that occurs in such infinitely small amount.

Manganese.-There is a notable difference in the relative amount of manganese found in the sulphide and the oxidized ore deposits of the Leadville district. The silicate and carbonate (rhodonite and rhodochrosite), which are the usual mineral forms in which manganese occurs in original ore deposits, are notably absent from the sulphide bodies at Leadville. Examination of a large number of analyses of sulphide ores has shown, moreover, that the amount of manganese is rarely over 2 per cent, and that the average is probably not over 1 per sent. In the oxide zone the great mass of the iron vein material contains a varying percentage of manganese oxide, and with increase in the proportion of this metal the whole mass assumes a brown-black color and is known to the miners as black iron. As a general rule the black-iron deposits seem to be more abundant in the upper part of the deposits near the contact with an overlying porphyry sheet, the manganese decreasing with depth. Large areas of such bodies carry from 15 to 25 per cent of manganese, with 20 to 30 per cent of iron, and when so situated that they could be very cheaply mined considerable shipments of such ore have been made from time to time to steel work as far east as Chicago.

The question which naturally presents itself is, What is the reason for such an abnormal increase in the percentage of manganese relative to that of iron during the alteration from sulphide to oxides The 
explanation which at first suggests itself, and which has been advanced by $\mathrm{Mr}$. Blow, is that an additional amount of manganese oxide has. been leached from the overlying porphyries by surface waters, since most of the porphyries contain small percentages of manganese, and in a variety of White porphyry, called by the miners "forest rock," it is visible in abundant dendrites on joint cracks. The apparent greater abundance of manganese immediately under porphyry contacts, which would have been the first reached by descending waters, favors this hypothesis. On the other hand, analyses show that porphyries which carry manganese contain an even higher percentage of iron, so that it would seem further necessary to prove that manganese oxide is either more readily dissolved or more readily precipitated than iron oxide. Vogt, ${ }^{a}$ in writing on the bog deposits of manganese, whose origin in Sweden and Norway he ascribes to the leaching of eruptive rocks, advocates the former idea, reasoning that in acidic eruptives the iron is most commonly in the form of insoluble oxides, such as magnetite, ilmenite, etc.; whereas manganese occurs in the silicates, whose decomposition yields a soluble product. It is a very generally observed fact, however, that in deposits containing oxides of iron and manganese, associated together, the manganese ore extends only to a limited distance below the surface, and that the proportion of iron increases with depth as that of manganese diminishes. Whether such deposits are original or secondary, they have in most cases reached their present condition through the agency of surface waters, whence it may be inferred that manganese oxide is more readily precipitated and more stable than iron oxide under such conditions.

In the present case, to prove that there has been an actual addition of manganese to a given deposit during oxidation it would be necessary to determine the total amount present in the ore before and after such oxidation, which is manifestly impossible. If there has been such an addition the manganese is likely to have been derived from the porphyries. In any event, however, some selective action in the relative precipitation of the two metals seems necessary to account for their present relative distribution.

\section{EARTHY MINERALS.}

Of gangue, or nonmetallic minerals, silica is the most abundant, but it rarely, if ever, occurs in the crystalline form of vein quartz. In sulphide ore bodies it is, like the metals, a replacement of the limestone, and the general term "jasperoid" has been given to designate all the varying forms of siliceous replacement. In the oxidized zone it may occur in granular form, retaining in great measure the limestone structure, or in lenslike sheets of chert, which often form the floor of an ore body, or, again, as the jasperlike matrix of the hard 
carbonate ores, and in the latter case seems to have been either trans.posed or added during oxidation. That there has been an actual addition of silica is not susceptible of direct proof, but the impression derived from a general inspection of the ore bodies is that on the whole the oxidized ores contain more silica than the sulphides.

The oxidized ores often appear very clayey, but except near the porphyry contacts, where there are clay bodies evidently resulting from the decomposition of porphyry, the percentage of alumina in the ores is very small, not amounting to over 1 or 2 per cent.

Barite and calcite are occasionally found in the oxidized ores, but form no considerable portion of them.

\section{DISTRIBUTION OF ORE.}

It would be rather inadvisable, even if it were possible, to give detailed descriptions of all the mine workings in this area, as they could hardly be made intelligible without detailed maps. An assembled map of the workings of the principal mines examined was made for the purposes of this study, and the most important general facts deduced from it, with regard to geological structure and distribution of ore, are represented on the accompanying map and sections. The outlines of the ore bodies are most indefinite in the mines themselves, owing to the very gradual and often imperceptible gradation from pay ore to slightly altered country rock, and it was possible to examine only a limited portion of the ore bodies that have actually been mined. For this reason, and in further consequence of the small scale of the map, it has been possible to indicate only in a very general and imperfect way the outlines and general distribution of the ore bodies. The object of the present chapter is to supplement these indications, as far as the data collected will permit, by a verbal description of the geological relations and distribution of the ore in the several mines or groups of mines. Such a description would necessarily be less intelligible to the general reader than to those actually occupied in exploiting the mines of the district. The general order will be followed of taking up first the ore bodies lying east of the fault, then those along the fault zone itself, and finally those in the region to the west of it, as far as it had been explored at the time of inspection. In accordance with local practice, ores that occur between the White and Gray porphyries will be called upper- or first-contact ores, those beneath the Gray porphyry second-contact ores, and those below the Parting quartzite third-contact ores.

\section{AREA EAST OF THE FAULT ZONE.}

CARBONATE HILL.

The sedimentary formations on Carbonate Hill have a fairly uniform dip to the east and south at angles of $15^{\circ}$ to $20^{\circ}$, but there 
locally sharp bends or warps where, for a short distance, the strata have buckled down at much steeper angles, at some places approaching the vertical. There is one prominent intrusive sheet of Gray porphyry in the Blue limestone whose thickness, though varying from point to point, is prevailingly 50 feet or more. Its position is also variable, since, though generally found below the middle of the formation, it cuts across the beds at some places so as to approach their upper surface, and may split into two or more sheets. Narrow, dikelike bodies of Gray porphyry are also found occupying a more upright position, but many of these have proved to be offshoots or apophyses from the main sheet, and it is probable that all of them are of this character. A few of these dikelike bodies extend up to tho White porphyry, either flattening out against its under surface or penetrating it a short distance beyond the contact.

Favorable positions for the accumulation of ore are near the under surfaces of the porphyry sheets, in the vicinity of the dikelike bodies and near the sharp bends of the strata, especially where the fold has passed into a small fault. The oxidizing action of the surface waters has reached rather unusual depths, in some places as much as 500 or 600 feet from the surface, probably because of the dip of the beds and the scanty covering of White porphyry above the limestone on its western face, so that with the exception of occasional residual masses of galena little or no sulphide ore has been mined on Carbonate Hill.

Ore has been developed most abundantly along the northern portion of the hill in the Crescent, Catalpa, Evening Star, Morning Star, Waterloo, and Henriette claims. At the time the original report was written there had been developed at the upper contact a large body of rich oxidized ore several hundred feet wide that had a general northeast trend along the four first-mentioned claims and reached its greatest development in the Evening Star, where it was up to 60 or even 80 feet thick. At the same time important bodies had already been developed at the second contact, or under the intrusive sheet of Gray porphyry. The main branch, outcropping near the Halfway House shaft, extended in a northeasterly direction into the hill, while the second or smaller branch, outcropping near the Forsaken branch and running northeast, joined the main shoot at about 300 feet from the outcrop. This ore body had a steeper dip than the upper contact for the reason that the Gray porphyry is crosscutting and has a slightly greater angle than the bedding planes. The manner of occurrence of the ore in these ore bodies is described in detail in the memoir of Mr. Ricketts, ${ }^{a}$ who made a special study of them during the summer of 1882. The upper-contact ores were so rich, averaging perhaps 70 to 80 ounces of silver per ton, that even with the high cost of treatment then prevailing they yielded very high net returns, and the 
Evening Star mine, with only 5 acres of ground, is said to have paid $\$ 1,400,000$ in dividends to its stockholders in a few years. In the immediately succeeding years the ore bodies were followed vigorously northward and eastward, thus leading in later years to the development of the great ore bodies in the Maid and Wolftone mines. Most of the mines in this part of the hill were long ago abandoned, and it has been impossible to obtain such data as would. permit an actual outlining of their ore bodies. It can only be said in a general way that a very great part of the ground in this portion of the hill has been found to be ore bearing, though it did not all pay to work at the time it was abandoned. The ore is by no means. confined to the contact with the porphyry, but extends into the sedimentary beds along joint and fracture planes, which, in the oxidized zones, are with difficulty distinguishable.

A structural feature which has most important bearing on ore development is a strong downward bend in beds along an east-west line, passing just north of the Harker, Seneca, and Maid-Combination shafts. In places along this line it amounts only to a steepening of the southward dip of the beds from an average of $15^{\circ}$ to $45^{\circ}, 60^{\circ}$, or even $80^{\circ}$, while at other points it passes into an actual fault, of generally small displacement, and often distributed on several planes of movement. $\Lambda$ long this line, especially on the upper and northern side of the bend, there has been an unusual ore concentration which can be traced, though not continuously, from the city of Leadville eastward across the northern ends of Carbonate and Iron hills nearly to Adelaide Park. In a vertical direction also mineralization has extended. through an unusual depth, ore shoots having been found at successively lower horizons, though with no apparent connection between them, down to the Transition series of beds between the White limestone and Cambrian quartzite. In the lower horizon the silver content of these ores falls off very noticeably, even when the lead percentage is very high. For instance, 45 per cent lead ores have been found to carry only 2 to 3 ounces of silver to the ton.

The upper-contact bodies have been in great measure scored off from that part of the northern portion of the hill that comes within the boundaries of the present map, so that it can not be determined whether any connection has ever existed between them and those to the west of the fault zone.

Farther south, in the Shamrock, Carbonate, Little Giant, and Yankee Doodle grounds, a second series of upper-contact bodies have been worked out, which, though rather disconnected, have as a whole a general northeasterly trend. Of the later developments in this region very little information has been obtained. Apparently the area of upper-contact ores has not been very much increased. Various disconnected ore bodies have been opened within the mass of 
the limestone alongside of or near the crosscutting dikelike bodies of Gray porphyry, but there is apparently no continuous second-contact ore body under the Gray porphyry sheet, though a few small pockets of ore have been found in places within the White limestone. From what has been learned of the distribution of ore under Carbonate Hill it.would appear to have had a decided tendency to spread out and dissipate itself toward the south, as if the ore-bearing currents had originated at the northern end of the hill and had moved from there southwestward along bedding and contact planes, depositing their load slowly as they proceeded, at first in comparatively continuous shoots and then in smaller and more scattered bodies as the distance increased.

STRAY HORSE GULCH DEPRESSION.

Under the valley depression between Carbonate and Fryer hills, now occupied by the two Stray Horse gulches, a secondary or transverse fold is suggested by the fact that the beds to the south have a southeasterly and to the north a northeasterly dip. A little north of the limits of the present map there is an unusual development of crosscutting bodies, both of the White and Gray varieties of porphyry, which may have produced a doming up of the overlying beds, and thus this apparent anticlinal structure. Whatever the cause, the result has been that erosion has cut down to an abnormal depth and successively lower horizons have been laid bare beneath the Wash on the several benches produced by faulting, while the entire upper contact and a portion of the second contact have been carried away. The existence, of such a second uplift was indicated on the original map, but an error was made in assuming an intervening syncline at the northwest base of Carbonate Hill around the Halfway House and Lower Henriette shafts. The reason for assuming this structure was that these shafts had apparently passed through White porphyry before reaching the ore, in which case the ore would have been upper contact, but in somewhat abnormal position. Subsequent developments, especially the discovery of the Niles and Pendery faults, have rendered it probable that this porphyry was simply a bleached and decomposed Gray porphyry in normal position above the second-contact ore body, as shown in Section IV (Pl. III).

The western continuation of this ore body has been mined in the Elk and Hussey grounds below the Niles fault, where it lies between the Parting quartzite and Gray porphyry, while the ore body found above the Parting quartzite in the drift running westward from the Niles-Augusta shaft is the probable continuation of the southern branch of this ore body that had been mined in the Forsaken and Lower Evening Star ground.

In the ground explored by the workings of the Elk and Hussey mines the general dip of the formations is to the southeast, there 
being from 45 to 60 feet of Blue limestone, or ore which replaces it, between the Parting quartzite and the overlying Gray porphyry. The quartzite floor is somewhat corrugated by minor folds, but in general tends to flatten out to the northwest, while in the opposite directions the formations have a sharp downward bend a short distance to the southeast of the shafts, then flatten in a trough or basin, beyond which they bend up sharply against the Niles fault. This sharp downward bend is in a general line with that running east and west through the north end of Carbonate Hill. The ore, though not continuous, occupies a very considerable area, both in the basin and on the higher ground to the northwest. At many localities it replaces the entire thickness of limestone between the Gray porphyry and Parting quartzite. It was found to be rather richer than the average second-contact ore, its greater richness being probably due to the fact that, being so near the Wash, it has been more exposed to secondary enrichment. Numerous drill holes were sunk in various parts of this ground down into the White limestone in search of ore bodies at lower horizons, but without avail.

A drift across the Pendery fault, run westward from the Elk shaft at about 220 feet below the surface, has furnished data with regard to that fault that have so important a general bearing that they will be given in some detail. Toward the fault the Gray porphyry has been scored off and the limestone and ore lie immediately beneath the Wash. The drift on crossing the fault passes through limestoie into brown clayey Lake bed material, which shows some sheetirg parallel to the fault plane. Against the limestone, which forms the east wall, standing at an angle of $62^{\circ}$, there still rests a thin clay seam, in places black; at others a White porphyry clay containing fragments of chert, of such a nature that it could not have stood against an original cliff. It is thus proved that there must have been movement on the plane of this fault since the Lake bed material to the west of it was deposited. Further evidence is offered b: the record of a drill hole, sunk from the same drift 160 feet west of the fault, which went through 78 feet of Lake bed material befo.c reaching White porphyry in its normal position above the Blue limestone. On the east side of the fault there is 30 to 50 feet of rock aboye this drift before the Wash is reached, so that we have a sudden deepening of the rock surface to the west of the fault of over 100 feet, much, if not all, of which differeizce in level may be attributed to movement on the fault plane since the Lake beds were deposited.

North of the general line of the Hussey workings a number of isolated shafts, such as the Last Chip, Ypsilanti, Ida Nyce, Hope, etc.. have found small ore bodies, presumably at the same general hoirzon as those of the Hussey, or second-contact bodies, but as the rather meager data obtained with regard to them were oral, and not 
checked by personal examination underground, the structure represented on this portion of the map is of a lesser degree of accuracy than the average. The map shows, for instance, that the Niles fault gradually dies out to the north and passes into an anticlinal fold. This is simply the hypothesis that best fits the facts determined in the surrounding region, for the workings of the Jolly mine are the most northerly that are known to have cut this fault. Small faults have been noted in the Heytrosser and other mines, but their location is too uncertain to admit of their correlation with the Niles or the Carbonate fault.

Still farther north, in Little Stray Horse Gulch, the Turbot shaft found that the Gray porphyry sheet had been scored off, only the underlying formations being cut by it. The workings from this shaft developed a body of low-grade second-contact ore above the Parting quartzite, and discovered in the White limestone several small disconnected bodies of ore, running from 10 to 30 ounces of silver and 5 to 12 per cent of lead, but nothing that would be considered a continuous ore shoot.

Farther west than the Turbot, where the Parting quartzite has been scored off, considerable bodies of third-contact carbonate ore have been worked in the Walcott and Hibschle ground, just east of the Pendery fault, which averaged 10 to 150 ounces of silver to the ton and yielded several hundred thousand dollars during the first half of the decade 1890-1900. This ore was found in the lower part of the White limestone, extending in places down through the Transition beds into the upper part of the Lower or Cambrian quartzite, where it carried only 3 to 5 ounces of silver. The ore body was thoroughly oxidized, 10 to 25 feet thick, and in places extended in streaks higher up into the limestone, as if the original sulphides had been deposited along cracks or joints. The general trend of the ore in the Walcott ground was northeastward, the body extending from the Pendery fault near No. 2 shaft to the north of No. 1 shaft, and apparently sending off an irregular branch to the southwest into the Hibschle ground. The general strike of the beds in the Walcott ground is nearly east-west, and the dip is $18^{\circ}$ to the south, but near the fault the beds bend down sharply to the west against the fault at $20^{\circ}$ to $30^{\circ}$, striking somewhat west of north, parallel to the fault plane. The richness of the ore, unusual at this horizon, is doubtless due to its lying immediately under the Wash and being thus subject to enrichment by surface waters. As shown in Section IV (PI. III), the No. 2 shaft was sunk in Wash and Lake beds just west of the fault, and the pronounced difference of level between the rock surface on either side of the fault affords additional evidence of movement on the fault plane since the deposition of the Lake beds, though as the depth of this surface west of the fault has not been determined, its actual amount remains uncertain. 
FRYER HILL.

In the upper left-hand corner of the map is represenued tne southwest point of Fryer Hill. It will be recalled that this is about on the imaginary line that crosses the district from northwest to southeast, along which the White porphyry is found to split into two sheets, one of which cuts at a low angle across the Blue limestone toward the northeast, leaving a wedge-shaped tongue of that formation on either side of it, while the other sheet retains its normal position above the whole Blue limestone formation. Thus, on Fryer Hill, there is a sheet of White porphyry below as well as above the Blue limestone. The intrusive sheet of Gray porphyry is also crosscutting, and traverses the lower sheet of White porphyry, thus rendering the structure very complicated and difficult to follow. The workings from the new Clark shaft of the Chrysolite mine, which was sunk a short distance southwest of the Roberts shaft of the same mine, disclosed the fact that this crosscutting sheet of Gray porphyry, which outcrops under the Wash at the Colorado Chief No. 2 shaft, rises toward the northeast, so that at the Clark shaft it has traversed all the Blue limestone, and beyond that point it cuts up into the overlying White porphyry, bending upward at an even steeper angle until, before reaching the surface, it assumes the position of a vertical dike.

The enormously rich ore bodies which made Fryer Hill famous in the early days were replacements of split-off portions of the Blue limestone entirely inclosed in White porphyry. It is to be remarked that this hill lies just northeast of the northwest-southeast belt or zone along which the White porphyry sheet itself splits, one part cutting diagonally across the Blue limestone at a very low angle and leaving wedge-shaped slices of this rock both above and below it. Subsequent underground developments have confirmed the generalization made in the original report with regard to the existence of this crosscutting zone, though, as will be shown in the forthcoming general report, it is much more irregular and complicated than was represented on the original sections, which were based on a comparatively small number of observed facts. They have, moreover, disclosed the further significant fact that the wedge-shaped portions of the sedimentary series, more particularly of the Blue limestone but also, at some places, those of the Parting quartzite and White limestone, in the vicinity of the crosscutting White porphyry, have been faviorable localities for the concentration of ore, and that where such ore bodies have been exposed by erosion so as to have been long subjected to the leaching action of surface waters, what remains of them has proved to be extraordinarily rich. It would naturally be expected, then, that the upper wedges, or those northeast of the crosscutting porphyry sheet, would be the richer, but if the lower or southwestern wedge happens to be faulted up to the vicinity of the surface and its covering of por- 
phyry be removed, it may also become very rich. An instance of this was seen in the Mikado mine, which lies on a bench only 300 feet wide between the Iron and Mikado faults and from which rich ore, worth many millions of dollars, was extracted, while the western continuation of the same ore bodies to the west of the Mikado fault, opened by the R. A. M. and Greenback shafts, though of enormous extent both vertically and horizontally, being still covered by 600 to 800 feet of porphyry, are low in silver and are not only unoxidized, but have suffered comparatively little secondary enrichment.

Another rich body, but in oxidized ore and in the upper wedge, was that of the Small Hope Mining Company, in the Forest City and adjoining claims, where $\$ 6,000,000$ worth of ore is said to have been taken out of 6 acres of ground. On Fryer Hill the Blue limestone is so completely replaced by oxidized ore that very little remains in its original condition. At some places the thickness of what was once limestone seems quite inadequate to represent the entire Blue limestone horizon, and it must be assumed either that some portions were floated higher up by the intruding porphyry and have been scored off, or else that portions were actually absorbed by the fused mass; but the general absence of any contact phenomena renders the latter assumption highly improbable. Those ore bodies that were under the lower or crosscutting porphyry were notably poorer in silver than the upper-contact ore, though carrying about as much lead. It has been impossible to learn what amount of exploration has been carried on in the White limestone, but whatever has been done has not apparently developed any large amount of ore. Still, by analogy with other parts of the district, it would be expected that some good bodies of ore should exist at this horizon, and they may yet be found.

Although very much warped, the formations in Fryer Hill have a general dip to the north and east; hence on the western end of the hill, where it slopes down to the terrace level, the White limestone and Lower quartzite come successively to the rock surface. The crosscutting sheet of White porphyry, which, on the southwest point of the hill that comes within the map, cuts down across the Blue limestone, farther north crosses the Parting quartzite also, and it would appear from the rather imperfect data obtained from certain shafts that it goes through the White limestone into the Lower quartzite farther north and west. It is possible, therefore, that somewhere in that direction it may come up through the granite, as it does at the mouth of South Evans Gulch.

Just east of the Pendery fault, at the west point of the hill and a short distance north of the area mapped, considerable bodies of manganiferous iron oxide have been mined through the shafts of the Allright No. 2 and the Fairview No. 4. These ores were found in the upper part of the Lower quartzite and were fully oxidized, but not 
being rich enough in silver to treat for that metal were sold to eastern steel works as ferromanganese. They carried 18 to 25 per cent of manganese, 22 to 29 per cent of iron, and 9 to 18 per cent of silica.

\section{AREA WEST OF THE FAULT ZONE.}

POVERTY FLAT.

North of the limits of the map the Pendery fault has been traced along the west base of Fryer Hill and across Evans Gulch, in a few places having been actually cut by mine drifts, but for the most part being proved by the discrepancy in the strata expose 1 by shafts on either side.

On the gently sloping terrace popularly known as Poverty Flat, west of Fryer Hill and north of the moraine ridge, several shafts have been sunk to contact, such as the Hofer, Stumpf, Neptune, Jason, Seeley, and Delante Nos. 1 and 2, which, while not yet successful in finding any large ore bodies in the Blue limestone, to which their researches have thus far been confined, have furnished important geological data as to the lay of the sedimentary beds beneath the covering of porphyry. It thus appears that these beds descend in a gentle slope westward, taking here and there a sudden monoclinal plunge downward, but exhibiting no considerable displacement by faulting, and that at the same time they have a still more gentle dip southward. The overlying White porphyry sheet grows thinner to the west and north, while the Gray porphyry sheet, which lies above it, tends to increase in thickness in the same directions, but has been scored off the higher part of the ground near the Pendery fault. Farther north, toward Evans Gulch, an increasing thickness of shales and grits of the Weber horizon is found between the porphyry cover and the Blue limestone. Furthermore, a rather persistent bed of quartzose sandstone, about 10 feet thick, is found in the body of the limestone, and is liable to be mistaken for the Parting quartzite, both here and in other parts of the region. It is generally, however, a finer-grained quartz than the latter, is thinner, and occurs generally at a higher horizon, though its position is not uniform. It may be simply a siliceous replacement. The Blue limestone in this region, so far as it has been explored, includes no large intrusive sheet of Gray porphyry corresponding with that which is so closely associated with ore deposition in areas farther south and east.

CAPITOL HILL RIDGE.

Under the moraine ridge which connects Fryer with Capitol Hill, the first deep exploration of the Downtown area was made in $1880 \mathrm{by}$ the sinking of the Bob Ingersoll drill hole to a depth of 500 feet. Though it found no ore, it furnished important geological information 
by disclosing a thickness of 140 feet (at least) of White porphyry beneath the Wash and the Lake beds, from which it was reasoned that the Blue limestone must lie at a still greater depth. It has since been proved that had the drill gone 50 feet deeper it would have reached the limestone. More than ten years later a shaft was sunk a short distance southeast of the drill hole, and a drift run eastward at a depth of 460 feet $\left(9,850\right.$ feet) ${ }^{a}$ struck the Blue limestone within 100 feet of the shaft, rising at an angle of $50^{\circ}$ toward the east. About 140 feet farther east the drift cut the Pendery fault, the great volume of water coming from which so enhanced the cost of mining that, after the ore above this level had been stoped out, work was abandoned for a number of years. When mining in other parts of the Downtown area had lowered the water level somewhat, mining was resumed here, and the ore was followed on the dip to the west of the shaft 128 feet deeper $(9,722$ feet $)$. When the ore above this level had been extracted another period of rest ensued, until, in 1905, a drift run in from the Coronado shaft on the 660 -foot level $(9,645$ feet) struck the ore body still farther west and nearly 60 feet deeper. This brief statement illustrates some of the vicissitudes to which mining in the Downtown district is subject. The ore in the Capitol, or Northern mine, as it has sometimes been called, is all upper-contact ore, none having yet been found beneath the intrusive sheet of Gray porphyry. It occurs at the immediate contact with the overlying White porphyry and extends to varying depths down into the body of the limestone. It is rather irregularly distributed, but in general arrangement has a tendency to form two shoots running in a northeasterly direction.

The geological structure in the Capitol ground is peculiar and significant. Within 10 feet of the Pendery fault the beds are dragged up into an almost perpendicular position by the movement of the fault, and the drift on the first level cuts through a wedge-shaped tongue of Gray porphyry dragged up from the intrusive sheet below before entering the granite which forms the foot wall of the fault. West of the fault the beds assume a westerly dip of $20^{\circ}$ to $25^{\circ}$, and then, within 100 feet of the shaft, turn sharply down at $50^{\circ}$, the dip growing gradually less steep west of the shaft. In the steeper part broken and crushed material gives evidence of an actual downward slipping movement along this contact, which increases toward the south, as will be seen later, and finally passes into the Cloud City fold fault. At the Newell shaft, which was sunk a few hundred feet farther west, the contact is considerably above its lowest point in the Capitol ground, and a drift run westward found it still rising in that direction, while the Villa shaft, still farther west, found it immediately under the Wash at a still higher level ( 9,975 feet), thus proving con-

\footnotetext{
a Figures in parentheses in the text denote the elevation above sea level of the point referred to.
} 
clusively the existence of a synclinal basin, as shown in Sections I, III, and IV (Pls. II and III).

The rise of the limestone at the Villa shaft seems to be local and abnormal, since the contact is over 100 feet lower at the Delante No. 1 shaft, a short distance farther north; for which reason it is assumed to be on the crest of the ridge, and that toward the west, as shown in the sections, the beds continue their normal westward dip for a considerable distance. Whether this is actually so and how far this dip may continue can be calculated only when shafts or drill holes shall be sunk to contact west of the line of. Harrison avenue. In any event there is a very considerable area of possible ore-bearing ground in this vicinity which has thus far been practically untested.

\section{CORONADO AND SIXTH STREET GROUND.}

The sharp downward bend of the strata in the Capitol ground passes southeastward into a distinct fault which runs a short distance northwest of the Coronado shaft southwesterly past the Sixth Street shaft, and is undoubtedly the same fault which was struck by the Cloud City shaft, though it has not yet been continuously traced. What is apparently an eastern branch of the same fault is cut by the drift connecting the Coronado with the Capitol mine (9,645 feet), where it has a slight downthrow to the north. Whether it continues to connection with the Pendery fault or dies out before reaching it had not yet been determined.

Northwest of the main Cloud City fault, in Coronado ground, is a shallow syncline corresponding to that between the Capitol and Newell shafts, whose axis is approximately parallel to the fault, but whether this structure extends as far south as the Cloud City shaft remains yet to be proved. The upthrow of the fault is normal and to the southeast, but the amount of displacement of this, as of all fold faults, is extremely variable, since it becomes nil where it passes into the fold. In this case the throw increases to the southwest and the vertical separation is over 200 feet on the line of Section V (Pl. IV). As the beds bend sharply as they approach the fault from either side, the actual amount of throw, or movement on the fault plane, is somewhat uncertain.

Up to within very recent years the workings of the Coronado mine were confined to the upthrown or southeast side of the fault, but since the last consolidation of mines in this region work has been carried on at deeper levels, and second-contact ore beneath the Gray porphyry sheet has been found in the bottom of the syncline due west of the Coronado shaft. It is oxidized, but its extent and value are unknown.

In the earliest developments a large body of upper-contact ore is said to have been worked on the east of the shaft, but as these work- 
ings have not been reopened since the "Flood," a they could not be examined. It probably corresponds to an upper-contact body that formerly overlay the Walcott body, whose western continuation would naturally have been found in the Coronado ground. A small body of upper-contact ore was found directly northeast of the Coronado shaft, but most of the ore worked later between the shaft and the fault was in scattered bodies. It occurs both above and below the intrusive Gray porphyry and within the mass of the limestone. The Gray porphyry is much decomposed, and is in places traversed by 1-inch seams of manganese oxide. Its horizon rises eastward. On the third level $(9,702$ feet), southeast of the shaft, a good deal of second-contact ore has been worked immediately above the Parting quartzite. This would appear to be a westward continuation of the Elk-Hussey ore shoot. At a still lower level a body of ore has been developed in White limestone, in close proximity to the Pendery fault, which is evidently a western continuation of the Walcott ore shoot.

Midway between the Coronado and Sixth Street shafts a very large ore body, averaging in places 80 feet in thickness, was found under the Gray porphyry associated with a sharp downward bend of the formation, which at some places passes into a cross fault with a southeast strike and an upthrow to the southwest. The under surface of the Gray porphyry is very irregular, tongues or offshoots protruding here and there into the ore beneath.

From the upper level $(9,780$ feet) of the Sixth Street shaft a firstcontact ore shoot was worked which has a northeast trend. It lay above the Gray porphyry, and extended in places for 30 feet up into the limestone, but whether it reached the White porphyry contact is not known. Though less extensire and thinner than the secondcontact body last mentioned, it was on the average rather richer in silver.

There is some uncertainty with regard to the geological structure of the ground west of the Sixth Street shafts (two shafts were sunk only 50 feet apart), which could not be worked out satisfactorily, owing to the inaccessibility of the upper and older drifts. There is some faulting between the two 'shafts, but the displacement does not seem to be sufficient for the Cloud City fault, and it may be only a parallel break. Again, a western drift on this upper level ran into

\footnotetext{
a About 1896 the labor unions obtained such complete control of the district that they not only stopped work in all the mines, but obliged the mine owners to draw their pumps, and the mines consequently filled up with water. This period is popularly spoken of as the "Flood." During the years that the drifts remained under water they gradually filled up with the lime sand, called by the miners "dolomite sand," that results from the disintegration of the Blue limestone. As the sand is extremely fine and preserves the original color of the limestone, its deposit in the drifts so closely simulates the bedding of the original limestone that, in reopening drifts cut through limestone, it is often difficult to distinguish this later deposit from the parent rock.
} 
the Wash 200 feet west of the No. 1 shaft, which indicates a depression in the rock surface under the Lake beds-probably the old stream bed that forms the bottom of the Stray Horse depression.

\section{MIDAS-PENROSE GROUND.}

To the southeast of the ore bodies above described the ore horizon in the Blue limestone stands at a somewhat higher level, as disclosed by the drifts running from the Midas and Penrose shafts; but this is apparently due to a rise in the Gray porphyry sheet, since, as shown in Section XII (Pl. VII), the general tendency of the sedimentary beds is to descend gently to the southward. Around these shafts is the most extensive area of ore-bearing ground in the Downtown district. On the map most of the ore bodies have been designated second-contact ore because they lie beneath the Gray porphyry sheet; but Section XII (PI. VII) shows that on that line the ore is all in the uppermost part of the Blue limestone, though it necessarily lies below the Gray porphyry sheet when that sheet has spread out immediately under the White porphyry, as is the case around the Penrose shaft and for a considerable distance to the north and east. The unusual concentration of ore in this vicinity is due doubtless to the irregular manner in which the Gray porphyry sheet has cut across the beds and sent off tongues and branching sheets at different horizons. The general structure and relations of the ore body are seen in Section $V$ (Pl. IV), which runs southeastward through the Midas shaft, and in the parallel Section VI (Pl. IV), which cuts the Penrose shaft, as well as in the strike Section XII (Pl. VII).

Midas shaft.-Near the Midas shaft the Gray porphyry sheet rises to the White porphyry contact but dips gently down to the northwest and south, leaving a thin wedge of limestone between the two porphyries, which has been largely replaced by oxidized ore of good grade. The ore is streaked with clay resulting from the alteration of the underlying porphyry, of which, to a limited extent, it seems to be a replacement. To the north of the shaft it is 20 to 30 feet thick and about 150 feet wide, and appears to be in line with the great northeast ore shoot of the Penrose ground which underlies the Gray porphyry. Some ore is also found in the Midas greund, under the Gray porphyry, but its extent is not well known.

To the east of the shaft a broad zone of ore, up to 50 feet in thickness, runs north and south along the foot of the Pendery fault. This is second-contact ore underlying the Gray porphyry and may be considered an extension of the Elk-Hussey body. It is of rather better grade than the second-contact bodies in the Penrose, carrying on the average 12 ounces of silver, 0.01 to 0.02 ounce of gold, and $1 \frac{1}{1}$ per cent of lead, and has probably been enriched. 
At the second level $(9,750$ feet) a long drift was run in a general southeasterly direction between the Bison and Gray Eagle shafts through Blue limestone and Gray porphyry, finding ore dipping steeply westward beyond the latter shaft. In the last 20 feet the drift is said to have been in granite, which apparently must have been beyond the Wildcat fault.

Penrose shaft.-At the Penrose shaft, and for a considerable distance north and south, the Gray porphyry sheet lies immediately under the White porphyry along the line of Section XII (Pl. VII), but it sends off several offshoots to lower horizons, so that in many parts of the mine there are two sheets, one above the other, and great complications of structure result, which can not be fully described or mapped. The ore has accumulated under both contacts, generally in rather shallow troughs, and is very apt to fill most of the spaces between two sheets when they are in close proximity.

In a general way most of the upper or White porphyry contact ore lay northeast of the shaft in a belt running northeast-southwest on either side of the Weldon fault. This, as has already been stated, is a fold fault with an upthrow to the southeast of not over 100 feet, along and above which are the workings of the Gray Eagle, Pocahontas, and Orion mines.

The ore is apt to be thickest on the upper bench, where bodies of black iron up to 80 feet thick have been found. Such bodies are of low grade in silver, except near the immediate contact, where rich lead and silver ores generally occur. The large body of black iron northwest of the Gray Eagle shaft, for instance, carried 16 to 18 per cent iron, 31 to 32 per cent manganese, and 8 to 11 per cent of silica, with 6 to 8 ounces of silver; while the carbonate ores had 43 ounces of silver, $12 \frac{1}{2}$ per cent of lead, 25 per cent of iron, 0.7 per cent of manganese, and 16 per cent of silica.

The most important shoot in the Downtown district lies, however, north of the Penrose shaft immediately under the Gray porphyry, and in its most typicai development is over 50 feet deep and 150 feet wide, with a distinct northeast strike. This strike would carry it into the Midas ground, where, however, most of the ore lies above the Gray porphyry, which has come down in horizon, so as to leave considerable space for ore accumulation between it and the White porphyry. In the Penrose body it lies in trough-shaped channels under the Gray porphyry, the principal one trending northeast and smaller ones trending more to the eastward and tending to converge to the west. In spite of its oxidized condition, which renders structure lines obscure, it is possible to detect evidence of local folding and faulting, with axes in the direction of the shoots, which has rendered the ground favorable for the concentration and precipitation

Bull. $320-07-4$ 
of ore. There is the usual underlying bed or floor of black chert several feet in thickness, which is a siliceous replacement of the limestone. A peculiar white clay seam, containing small pebbles of porphyry, at many places divides the upper lead-bearing ore from the low-grade iron below. This may represent the outline of the original sulphide body. West of the shaft, on the same general southwest line, there is a large irregular body of low-grade iron ( 5 to 10 ounces of silver to the ton) 40 to 50 feet thick, which is unusually rich in manganese. At its southern end it is covered by 40 feet of Gray porphyry, which immediately underlies the White porphyry. At a point midway between this body and the shaft an isolated, dikelike body of Gray porphyry was observed, which has not yet been connected with any other porphyry mass. It stands in a vertical position, is 35 feet thick, and has a flow breccia at its contact with the limestone.

Bison shaft.-Due east from the Pendery the Bison shaft was sunk in an area of extremely complicated structure, where the ground is so sliced up by faults and branching sheets of Gray porphyry that it is very difficult either to work or to interpret. The abundant faulting has, however, been very favorable for secondary enrichment, so that unusually rich ores have rewarded the difficult labors of the miner. As for the structural problem, the solution represented on Section II (Pl. II) and Section V (Pl. IV), each of which passes near the Bison shaft, is believed to be correct in its broader features, though there are many complications in structure that can not be represented on a map of the present scale, and the ground could not be thoroughly studied, for the reason that the mine has been worked intermittently by different persons and the records not always preserved. In this ground is the point of an eastward bend in the Pendery fault, and across this bend a second fault constitutes the chord of the arc made by the Pendery fault. This fault, which is cut by the Bison shaft just above its first level, is normal, and is called the Bison fault. A little east of the shaft on this level is another small fault, with reverse throw, which has been interpreted as cutting off a wedge-shaped mass that has dropped down, while at the end of the drift is the main Pendery fault, which brings the Parting quartzite up against the Blue limestone. East of this fault, and about 80 feet higher, a west drift from the Niles-Augusta shaft struck a good body of second contact ore above the Parting quartzite. In the Bison workings to the east of the shaft there is a duplication of the Gray porphyry, which is supposed to result from its sending off an offshoot, as represented in Section II (Pl. II).

In the later workings of the mine, drifts run westward from lower levels cut the Bison fault and found large and valuable ore bodies beyond it, mainly in the limestone and under the White porphyry, but it is said that a second-contact body corresponding to the Niles-Augusta 
has recently been found. It will be observed that the line of secondcontact ore bodies has been opened intermittently in a direction due east from the Penrose shaft, and if followed farther eastward in this direction across the north end of Carbonate Hill, tends to correspond approximately with the sharp bending down of the strata to the southward, already noted in that region.

About 200 feet south of the Penrose shaft, under the Lazy Bill shaft, is an ore shoot which has the fissure form, like those occupied by the ore bodies on South Iron Hill, and is so far the only known example of this type of body in the present area. It lies under the Gray porphyry and has evidently been formed from solutions coursing along a fissure striking northeastward, with northwest dip, and eating out into the limestone on either side. Along this fissure were some large chambers of rich ore carrying 100 to 200 ounces of silver and 20 per cent of lead. Both strike and dip are irregular and wavy. As shown in the drift below (9,700 feet), the ore has pinched out, but the crack or fissure in the limestone can still be detected and forms what the miner calls a watercourse or channel along which surface waters still seep down.

STARR AND CLOUD CITY MINES.

Neither the Starr nor the Cloud City mine had produced much ore at the time of examination, and the ore bodies that had been worked in the former ground are no longer accessible, so that not much can be said about actual ore development. 'As the geological structure may have some bearing on future development, and its description needs graphic illustration, the section in fig. 1 has been constructed from such data as could be obtained. It runs southeast through the Cloud City and Starr shafts and a little south of the Alice shaft, following the dip of the beds, which thus appears steeper than in many of the map sections, whose lines are not strictly at right angles to the strike of the beds. The principal ore bodies worked in the Starr ground have been near the Weldon fault, east of the shaft and immediately under the White porphyry. They were reached by numerous raises from the first level and evidently belong to the same general belt worked in the Penrose and Gray Eagle mines, to the northeast, and the Weldon, to the southwest.

As the formations rise to the northwest, there is a slight local fault near the place where the Gray porphyry sheet, whose thickness varies from 30 to 50 feet, crosses the second level $(9,735$ feet). Some ore has been developed to the west of the Starr shaft under the Gray porphyry sheet, but the country rocks in this part of the ground have been so softened and decomposed by the seepage of surface waters, indicating a probable close proximity to the rock surface, that mining is difficult and expensive, and the workings soon become inacces- 
sible to the visitor. The drift running from the Starr to the bottom of the Alice shaft $(9,750$ feet) in the last few feet passes through a peculiar broken material (shown also at the top of several upraises) that has apparently been subjected to such differential movement within its mass as would take place in landslide material. The struc ture lines are obliterated, and it is full of broken angular blocks very much resembling decomposed Gray porphyry.

The bottom of the Alice shaft is in a bed of quartz sand, such as forms a very persistent stratum, 10 to 12 feet thick, in the lower part of the Blue limestone throughout the Penrose ground. The revelar tions made by the Cloud City shaft, which passed through similar broken material immediately under the Lake beds, suggest that the

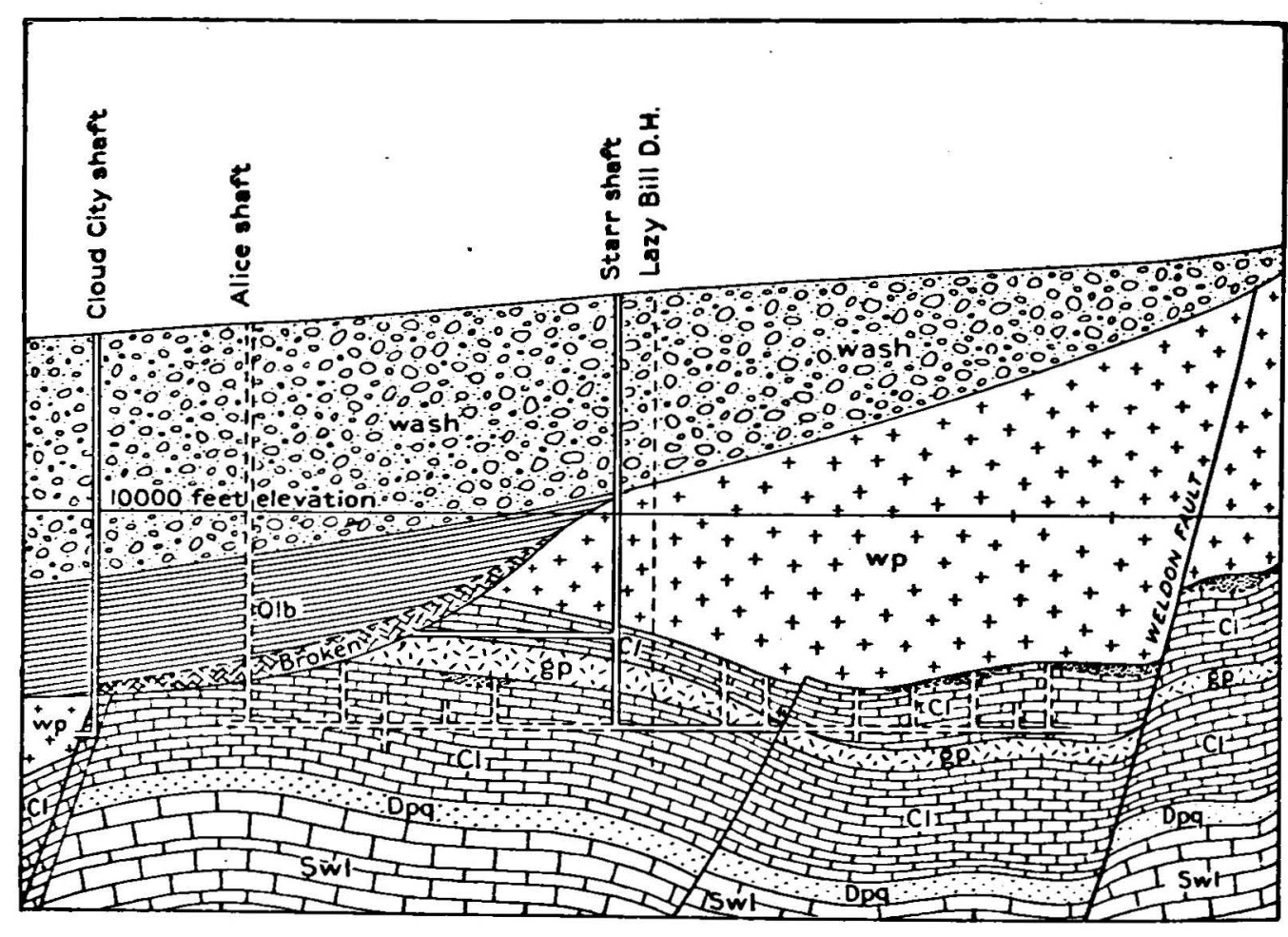

Fig. 1.-Section through Cloud City and Starr shafts. (For meaning of symbols see PL. I.)

rock surface lies at an angle so steep that there has been an actud slipping downhill of a considerable thickness of moistened and rotted rock on what happened to be an exceptionally steep slope of the surface of the rock beneath the Lake beds.

The double line given on the section under the Lake beds indicates the possible thickness of this broken material, though it is impossible to determine any well-defined boundary lines for it, since it grades off insensibly into the formations abore and below. The abnormal steepening of the rock surface brings the upper part of the Bhe limestone and the included Gray porphyry to outcrop along this line, a phenomenon that could not be observed elsewhere owing to the absence of drifts, so that the crescent-shaped form of the outcrop indicated on the surface map is for the most part theoretical. It is 
based on the assumption that there was a gullylike depression in the rock surface beneath the Lake beds in this region which thus far has been cut only in the north drift from the Cloud City shaft. There is, however, a very considerable area of unexplored ground between the Alice, Sixth Street, and Penrose shafts, in which it may yet be found. It is possible that it may have some connection with the depression already noted west of the Sixth Street shaft.

At the Cloud City shaft the fault movement is distributed on two planes running a little east of north and about 50 feet apart, while a wedge-shaped mass has been let down to the west of the western plane on which the displacement is reversed. This renders the structure at the very bottom of the shaft rather difficult to interpret, especially as the drifts on the first level $(9,710$ feet) cut these planes diagonally. White porphyry is found in place beyond all the faults, however, and in it the old stream bed, already mentioned, has been cut through by the north drift, in which it is seen to be about 70 feet wide and filled with bowlder wash. The Blue limestone contact is cut by this drift 75 feet from the shaft and also in several winzes sunk to the north and west, which indicate a dip of $15^{\circ}$ or $20^{\circ}$ in this direction. It is very possible, therefore, that the synclinal structure found in the Capitol ground may be repeated here, though probably in less pronounced form. It is assumed that the vertical separation produced by the movement of this fault is from 150 to 200 feet; hence to properly prospect the ground to the north and west the shaft should be sunk 200 feet deeper. If the Gray porphyry is found to extend in that direction, there is very good reason for assuming that valuable ore bodies may be found.

\section{WELDON GROUND.}

The Weldon ground, although it includes only a single claim, 300 feet wide, has produced a remarkably large amount of rich uppercontact ore, carrying several hundred ounces of silver per ton. The main production has come from the lower (No. 2) shaft, which was sunk to the bench below the Weldon fault. The No. 1 shaft, opened earlier but long ago abandoned, was sunk in the midst of the fault zone, and cut the Pendery fault a little below its second-level station $(10,068$ feet $)$. It disclosed a complicated structure, the general features of which are shown in Section VII (Pl. V), which, however, passes to the north of the Weldon No. 2 shaft, whose workings are shown on Section VIII (Pl. V).

No. 1 shaft.-At the No. 1 shaft several small ore bodies were found along the upper contact on the steeply sloping bench east of the Pendery fault, both north of the shaft, toward the Pocahontas, and east of it, toward the Pendery and St. Mary's shafts, where it lies in troughlike depressions called "swags" by the miners. A drift 
run westward from the bottom of the shaft $(9,910$ feet) cut the Pendery fault, finding beyond it a body of Gray porphyry which was at first supposed to be a dike, but is really an intrusive sheet of Gray porphyry turned up steeply against the fault, the upward bend having been so sharp as to produce some slipping along its upper contact. Some upper-contact ore was found on the bench between the Pendery and Weldon faults, but on neither side of the Pendery fault in this region does the ground appear to have been thoroughly explored for second-contact ore.

No. 2 shaft.-The beds on the bench reached by the Weldon No. 2 shaft are compressed into a series of gentle wavelike folds. To the east of the shaft they descend 25 feet in a hundred, the contact coming down to the drift level (9,780 feet) and then rising at first gently and near the Weldon fault very steeply, so that at the fault the contact is 90 feet above the level. At the same time, the beds dip slightly south, so that the ore, which is 20 feet thick above the level on the north side of the claim, is entirely below it on the south. About 40 feet south of the shaft the White porphyry contact comes down into the level with a southwest dip, showing its characteristic chert fragments and being somewhat sheeted as the result of movement along the plane of contact. On the Weldon fault considerable ore was found in the upper 6 feet, which had been dragged in from the adjoining ore bodies.

To the west of the shaft the beds are still more crumpled and in some places slightly faulted. The Gray porphyry is very irregular and very difficult to trace. Farther west.it appears to split, one branch rising above the first level $(9,780$ feet), as it does in the Starr ground; the other descending and possibly connecting with that in the Bohn ground, which stands at a much lower level-9,600 to 9,669 feet.

\section{BOEN MINE.}

There is a good deal of uncertainty about the structure of the ground between the Starr, Weldon No. 2, and Bohn shafts, the rocks being very soft and decomposed and the old drifts largely inaccessible. The intrusive sheet of Gray porphyry is about 60 to 70 feet thick and stands at a lower level relative to the White porphyry contact than at either the Starr or Weldon shafts. In the Bon Air ground, to the south, it retains the same thickness and descends at the same dip as the limestone, or possibly a little steeper dip. To the west in the Bohn ground this sheet rises in horizon, not uniformly but in gentle rolls, and thins out to 35 and then to 25 feet in thickness. At the Bohn shaft it sends off a vertical dikelike offshoot, 25 feet thick, which cuts the first level of the Bohn mine (9,778 feet) just south of the shaft. The ore in the Bohn ground has been mostly taken from the upper contact to the south and west of the shaft, but on the second 
level $(9,718$ feet $)$ some small pockets of ore have been mined under the Gray porphyry. The formations in general descend to the south and southwestward, and at 240 feet west of the shaft a zone of porphyry and limestone breccia running north-south may, it is thought, represent the Cloud City fault. It is not, however, seen in the upper level, nor does there seem to be any considerable displacement of the beds on either side. As disclosed in the Home Extension shaft, still farther west, where the contact stands at 9,680 feet, the drop might be accounted for by the slope of $22^{\circ}$. It is probable, however, that there is a downward displacement of about 50 feet.

BON AIR MINE.

At the time of the examination this mine was not actively worked and the ore stopes were not visited. They lie mostly above a single level $(9,669$ feet), by which the mine was then opened, and at the White porphyry contact. This contact has an average slope of $10^{\circ}$ to the south, and at one point comes down in a synclinal roll to the floor of the level. The ore bodies are said to be from 10 to 25 feet in thickness and of rather low grade, averaging about 8 ounces of silver to the ton. They are generally underlain by chert in varying thickness up to 10 feet. Three drill holes have been sunk from this level down to the Parting quartzite without finding ore, but this seems to be insufficient ground for assuming that it does not exist there. To the east, toward the P. O. S. mine, the beds rise at an angle which steepens as this ground is approached, the more rapid rise being probably influenced by the general uplift along the fault zone. As the P. O. S. mine was being actively worked at the time visited and was studied in detail by Mr. Irving, it will be described rather fully, since it presents a structure typical of the fault zone.

\section{P. 0. S. MINE.}

The P.O.S. mine is opened by a shaft situated on the western slope of Carbonate Hill, 350 feet southwest of the Portland, 600 feet northwest of the Can shaft, and 640 feet east of the Bon Air shafts. It reaches the White porphyry-limestone contact at a depth of 507 feet (9,791 feet) and has two levels at elevations of 9,771 and 9,762 feet, the drifts of the upper level lying to the east and those on the lower level to the west of the shaft. The ore thus far extracted has been found at this contact, which has a generally southwesterly dip at an average angle of $25^{\circ}$ to $30^{\circ}$. Locally, however, there are sharp downward bends in the strata along which ore is apt to accumulate, as shown in fig. 4 , section $\mathrm{BB}$.

At the contact the White porphyry is decomposed and altered for a distance of 6 feet or more to a soft white clay, which is sheeted or foliated parallel to the bedding of the limestone, and the clay contains fragments of black chert which have been sheared out of the 
Blue limestone, where it normally belongs, thus affording conclusive evidence of movement on this plane. The clay is much stained by manganese oxide, and dendrites of manganese extend up into the porphyry above the altered zone.

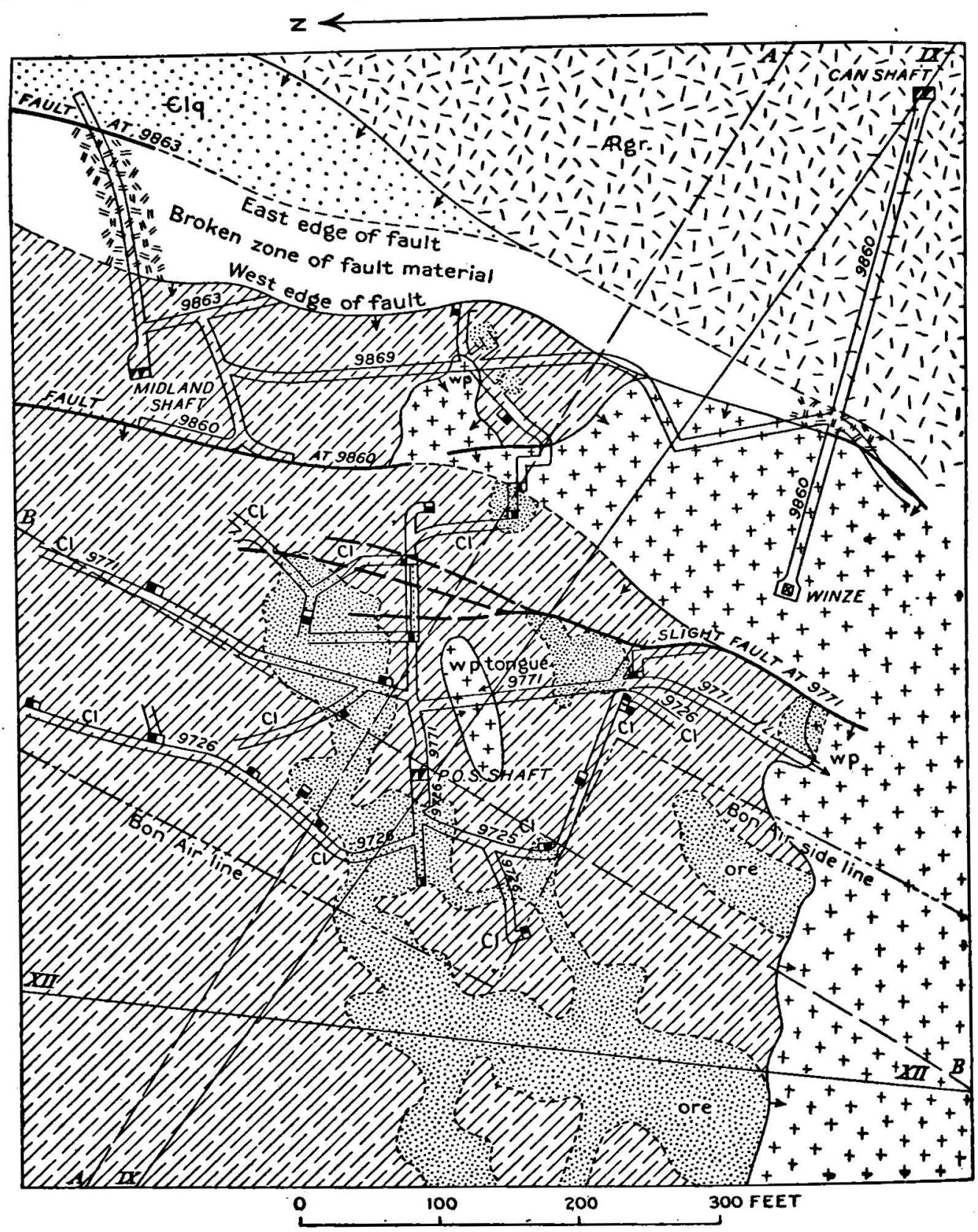

Fig. 2.-Plan showing the workings of the P. O. S., Midland, and Can mines at the working levele and the rocks exposed by the drifts on those levels, the elevation of the latter above sea level being indicated by figures within the drifts. The outlines of the ore bodies are projected onto this plan. Figs. 3 ard 4 are partial sections along the lines $A A$ and $B B$, which run respectively southeast and southwest acrom the area of the plan. Symbols: $\boldsymbol{R g g}=$ granite; elq=Cambrian quartzite; $\mathrm{Cl}=\mathrm{B}$ lue limestone; WD White porphyry.

In the southern portion of the mine the dip of the formation brings the porphyry down across and below the level of the upper drifts, 2 shown on the map.

Faults.-The Pendery fault is represented by a zone of broken rock, mostly quartzite ( $b q$ on fig. 3 ), which is 25 feet wide in the Can ground and reaches 100 feet in the Midland ground. The vertical separation 
of this fault, as shown on the general section, IX (PI. VI), is about 850 feet for a throw of about 1,100 feet. 'The east drift from the Midland shaft, after passing through about 100 feet of fault material, mostly broken quartzite, penetrated solid Cambrian quartzite beyond. It is

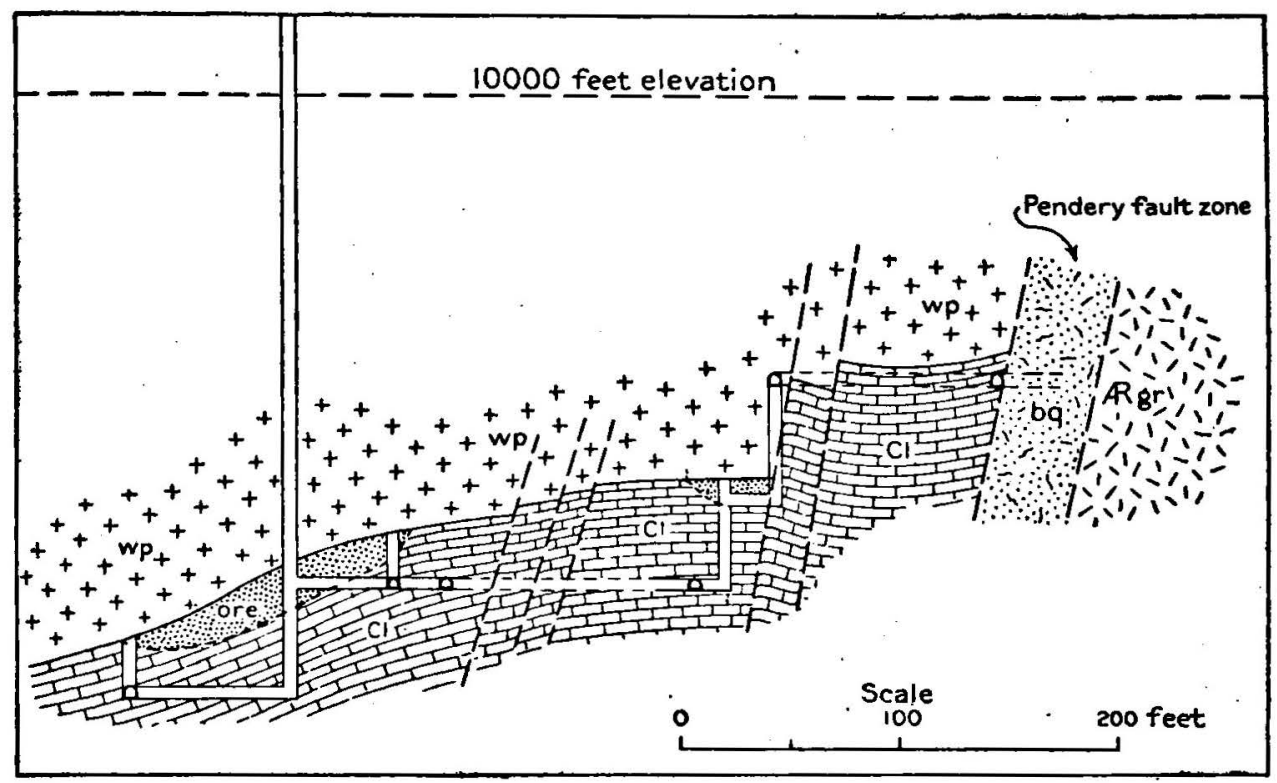

FIG. 3.-W orkings of P. O. S. mine. (For meaning of symbols see fig. 2.)

assumed here that this lies between the Pendery and the Carbonate faults, the latter having bent westward to join the Pendery just north of the Can shaft. This is, however, only an assumption, as this part of the ground has not yet been explored.

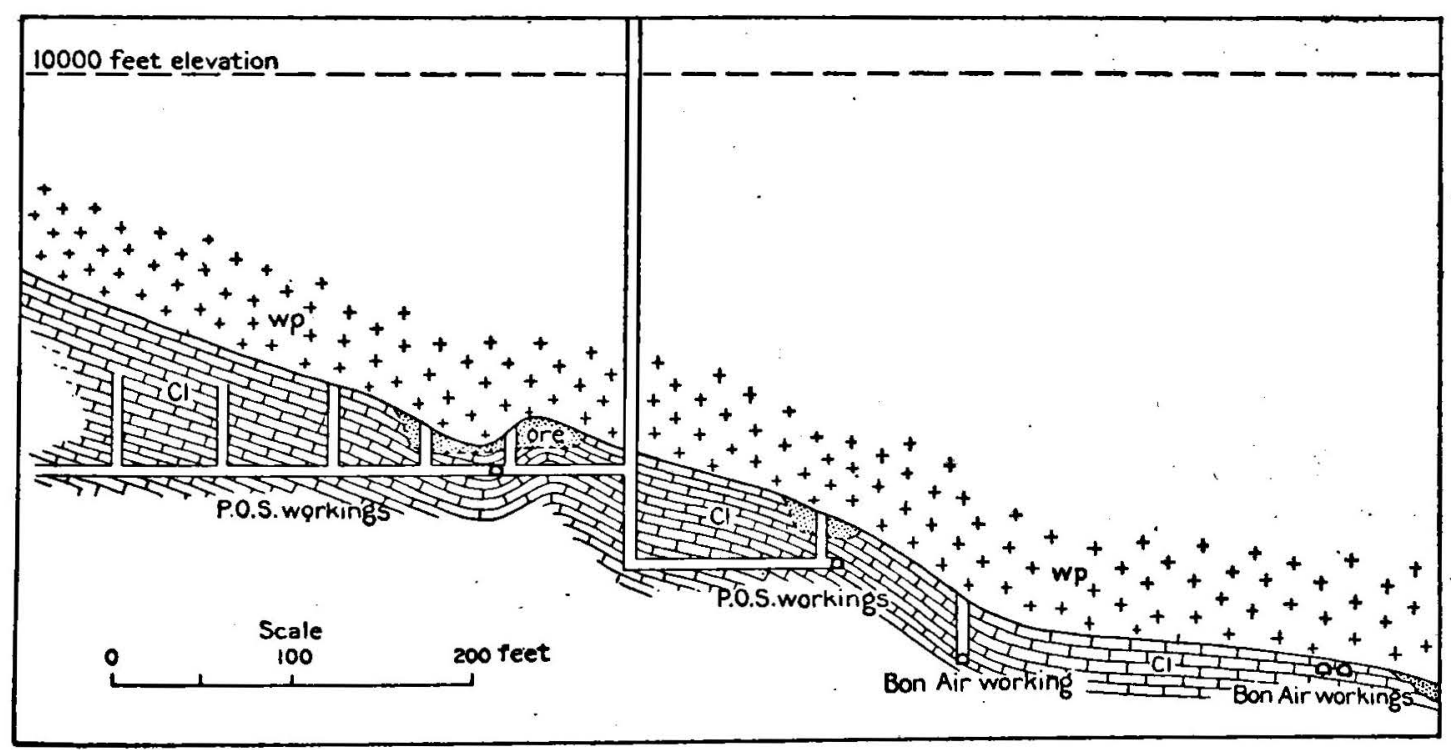

Frg. 4.-Workings of P. O. S. mine. (For meaning of symbols see fig. 2.)

Another fault runs parallel to the Pendery, about 200 feet to the west, which is well exposed in various upraises. It has a throw of not over 65 feet, but, owing to its limited lateral extent, has not been represented on the general map. A number of still smaller faults run 
for short distances parallel to this, which apparently converge to the south and finally join it, as shown on the map and in figs. 3 and 4. They illustrate the complication of smaller faults which are apt to accompany the larger ones and render it difficult to work out $r$ ll the details of the underground structure.

Ore.-The ore of the P. O. S. mine is an altered manganiferous iron, some of it carrying as high as 200 to 300 ounces of silver. The silver is often visible in beautiful greenish crystals of horn silver lining cavities in the ore. Cerussite is found irregularly disseminated through the siliceous "liver-colored" rock, constituting a hard carbonate ore. It occurs normally in a mass of black iron, but immediately below the porphyry, as shown in the diagrammatic section below (fig. 5). The ore in the P. O. S. occurs in three distinct shoots, only one of which had been sufficiently explored at the time of visit to disclose fully its geological relations. This lies on the north side of the shaft, but does not extend up to the fault that separates the P. O. S. from the Midland workings. It lies close up against the White porphyry, from which it is rarely separated by any unreplaced limestone. It is extremely irregular in outline and varies from 20 to 30 feet in thickness.

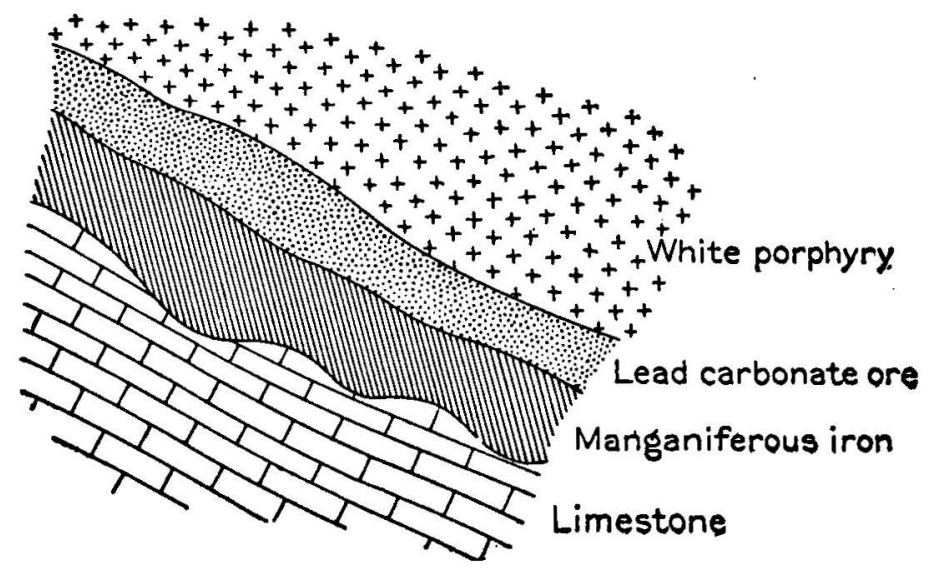

FIG. 5.-Diagrammatic section of ore body, P. O. S. mine. Shows the occurrence of the carbonate ore next to the White porphyry.

To the west of the shaft on the lower level is the northeastern continuation of an ore shoot which extends into the Bon Air ground. Other ore bodies on the upper level and south of the shaft had just been opened at time of visit and were about 25 feet in thickness. The ore is cut off on the east by a smooth limestone wall, dipping $65^{\circ}$ west- the foot wall of a fault that can not have much throw, since the bottom of the Can winze on the level above and farther east is still in White porphyry.

Little or no ore was found in the Midland mine, whose workings are in ground so faulted and broken as to make successful mining rather difficult. In the Can mine, whose workings are largely in granite or White porphyry, no ore has been found. 
So far as can be learned, no large amount of ore has been mined south of the P. O. S. ground. Considerable underground exploration has been done from the May Queen and O'Donovan Rossa shafts, but they were evidently unsuccessful in finding ore and have long been abandoned.

The California tunnel was visited in 1880 and found to run 700 feet into the hill, of which the first 585 feet went through White porphyry to a fault, which is evidently the Pendery fault. The tunnel passed beyond it into a limestone, supposed to be the Blue limestone, which bends downward against the fault plane with a western dip of $40^{\circ}$, but farther in shows a normal southeastern dip.

An east drift from the California Gulch shaft, at the southern edge of the map, also cuts the Pendery fault, whose position on the surface has been calculated with reference to the measurements given by the working maps of this mine, the mine itself being closed down. The shaft passed through the intrusive Gray porphyry and found a considerable thickness of mineralized matter beneath this, as well as beneath the White porphyry.

The tracing of the Pendery fault thus far may therefore be regarded as rather accurate, but with regard to the southern continuation of the Carbonate fault there is less certainty. It has not been actually cut underground south of the Ætna mine, and its curving connection with the Pendery fault, represented on the map, is a theoretical assumption deduced from the apparent converging direction of the two faults and the failure to find any well-defined duplication of beds on the outcrops on the steep southwest slope of Carbonate Hill. The latter is rather negative evidence, as the covering of slide rock is so deep that there are very few actual rock outcrops, and the prospect holes that have reached rock in place are very scattered and difficult of access. On the other hand, drifts running eastward from the Toledo Avenue shaft cut a fault that crosses California Gulch in a northerly direction, and a wedge-shaped fault was found 375 feet from the mouth of the Prospect incline, halfway between that shaft and the Carbonate incline. Moreover, according to the outlines indicated on the map, the limestone cut beyond the fault by the California tunnel must be the lowest part of the White limestone instead of the Blue limestone, as was supposed at the time of visit in 1880 . Whether the Carbonate fault is correctly represented on the map or continues southward in a more easterly position, faults of minor throw undoubtedly cross California Gulch east of the Pendery fault, as is shown by discrepancies in the beds, and one of them passes through the Revenue shaft on the flat south of the gulch. The structure shown on Section II (Pl. II), which has been continued to the west of the area mapped in order to incorporate the data given 
as to rocks passed through by the Valentine and Maple Street shafts, shows that the descent westward of the Blue limestone is not so steep but that it can be accounted for by a westward dip in the beds which is not greater than is elsewhere observed in the Downtown area, though a fault of small throw is said to have been proved by underground workings west of the A. V. shaft and a little east of the Valentine shaft.

Prospecting in this southern area must always be attended by considerable risk, as an indispensable preliminary is the sinking through 400 to 700 feet of necessarily barren material before the horizon of possible ore can be reached, and when reached there are as yet no well-defined lines of probable mineralization to guide the miner in his exploration. On the other hand, the highly altered condition of the rocks passed through by such shafts as the A. V., which have been sunk in this area, indicate a probable extension of the area of mineralization beyond that already explored underground.

\section{GENESIS OF ORES.}

\section{MISCONCEPTION OF ORIGINAL VIEWS.}

The explanations given in the original reports on the Leadville district of the origin and formation of the ores in limestone have been in many respects very generally misconstrued in subsequent publications. In some of these the writer is assumed to have stated that the ores were brought in by waters descending directly from the surface; in others, that the metallic contents of these waters were derived from the overlying White porphyry, neither of which views he actually held. It would seem that the authors of these publications must have formed their opinion from reading only the preliminary statement, published immediately after the close of field work in 1882, rather than from the more complete explanation given later in the Leadville monograph. In the former ${ }^{a}$ it was briefly stated with regard to the origin of the deposits:

1. That they have been derived from aqueous solutions.

2. That these solutions came from above.

3. That they derived their metallic contents from the neighboring eruptive rocks.

In the final report ${ }^{b}$ this statement was made more explicit, as follows:

With regard to the immediate source from which the minerals forming these deposits were derived, the following conclusions have been arrived at:

1. That they came from above.

2. That they were derived, mainly, from the neighboring eruptive rocks. 
By these statements it is not intended to deny the possibility that the material may originally have come from great depths, nor to maintain that they wert necessarily derived entirely from eruptive rocks at present immediately in contact with the deposits.

The facts and reasons on which these conclusions are based will be given in the following chapters.

At the time the preliminary report was in preparation capitalists were being urged by J. Alden Smith, State geologist, to sink deep shafts immediately down to the Archean, on the theory that, since ore-bearing solutions came from below, the Leadville ores must necessarily have ascended through fissures in the underlying granitic rocks, and the ore bodies found there, being nearer to the source, would be more valuable than those found in the limestone, his belief being that "these fissures and deposits will be extensively and profitably worked for centuries after the contact deposits now operated are exhausted." a

In the light of the geological investigations he had made, this seemed to the writer a mistaken idea, which, if followed, would result in pecuniary loss and might retard the development of the district; hence he made his statement strong, and, as results have since proved, rather too unqualified.

Geological studies of ore deposits up to that time had been, mainly, of veins that follow nearly vertical fissures in the rocks, of which the most natural explanation is that they are formed by ascending solutions; and in ordinary mine reports, for which, as a rule, but little study of the general geology of the district was deemed necessary, the rather perfunctory statement was generally made that the vein materials "came from below," without any very definite understanding on the part of the writer of what these words implied.

It was, moreover, generally assumed that all waters circulating within the crust of the earth came originally from the surface, descending under the influence of gravity and ascending again under the influence of heat - either the normal increment of heat within the crust, or that due to proximity with some cooling igneous mass. The modern idea that cooling igneous masses have given off enough occluded water to furnish a continuous underground circulation was then, and for many years afterwards, not considered tenable.

In undertaking the study of the Leadville mines, the writer proposed to take a new departure in making, as a preliminary, a thorough study of the geological structure, not only of the immediate vicinity of the mines but of the whole mountain region within a radius of about 10 miles around, and to base his attempt to explain the manner of formation of the ore deposits on the geological data thus obtained,

a Rept. on mineral and other resources of Colorado for 1881 and 1882, p. 64 . 
quite independently of whether the resulting explanation accorded with current theories or not. As it was his first study of any important group of ore deposits, he did not feel competent to go into abstract questions about their origin, much less to present a general theory of ore deposits, as some seem to have assumed he did; hence, in speculating as to the source of the metals, he thought it wiser, as the important object was to furnish a guide to the miner in his search for ore bodies (as stated explicitly in the text, Monograph 12, p. 572), "to leave out of consideration altogether the ultimate and purely speculative source and to confine the investigation to the more immediate source, about which it was possible to obtain some actual and demonstrable evidence." Then, after stating that the commonly received explanation for vein deposits is that they have been formed by directly ascending heated solutions, he said, " "In the case of the Leadville deposits, the inadequacy and even falsity of this explanation, except as applied to the ultimate source from which the metals may have been derived, is readily apparent." He then proceeded to give the reasons for this statement by showing that the form of the ore bodies was such as to lead to the conclusion that the ore-bearing bodies entered the limestone from its contact with the porphyry sheets. These contacts being the main channels of circulation and mainly at the upper surface of the limestones, "the few approximately vertical bodies [of ore] that have come under observation afford no evidence that their walls form part of a channel through which the ore currents came up from below;". $b$ hence, he concluded, "the above considerations seem sufficiently conclusive evidence against adopting upward currents as the direct source of the ore deposits of Leadville."

In further argument against the necessity of resorting to the unknown depths to find the source of the metals, the author proceeded to give the result of chemical tests of the country rocks, especially those of igneous origin, which showed that small amounts of vein material were found in most of the latter and that most of the varieties of porphyry, except the White porphyry, contained appreciable amounts of silver. Then, without attempting to decide which particular variety of porphyry the metals came from (which he explicitly stated was "too difficult because of the amount that had been removed by erosion since ore deposition "), he said: "The foregoing reasons seem to favor the probability that the ores may have been derived, in part at least, from one or more of the bodies of porphyry which occur in the region. $c *, * *$,

While the intimate genetic connection between the ores and porphyry was established, as he conceived, with reasonable certainty, 
he admitted that there was still some doubt about the ultimate source of the metals, remarking: ${ }^{a}$

It is possible that in future years, when mine workinge shall have been extended over areas where the ore horizon exists at considerable depths below the surface and other eruptive channels have been found and critically examined, evidence may be obtained that ore solutions have ascended along these channels from below.

The idea that was in his mind in saying this was that inasmuch as the Gray porphyry within the mineral area is a distinctly later eruptive than the White porphyry, if the channels were found through which this porphyry had reached the Blue limestone horizon these might prove to be also the channels through which the ore-bearing solutions had reached that horizon.

\section{CRITICISMS.}

In the time that has elapsed since the Leadville report was written some of the conclusions have been severely criticised by prominent geologists, notably the genetic connection of ore deposition with igneous eruption and the metasomatic replacement of limestone by ore, but practically all of these conclusions may now be regarded as universally admitted by economic geologists, with the exception of the determination of source of the metals. With regard to this, it may be said that in treatises on ore deposits written within that time the general opinion seems to be that the writer wrongly conceived the ores to have been brought in by descending waters, but that mining engineers, who bad become more familiar with the deposits by later and more continuous underground observation, had proved them to have been brought up from below by hot ascending solutions.

Having already endeavored to show in what respect the author's statements were misconstrúed, it may be well to see how far these statements are justified by a careful consideration of the articles on which they were based.

The mining engineers to whose writings references had been made were Messrs. F. T. Freeland, ${ }^{b}$ Charles M. Rolker, ${ }^{c}$ and A. A. Blow ${ }^{d}$ Of these, Mr. Freeland did not discuss at all the source or origin of the metals. Mr. Rolker, confining himself to the direct source, objected chiefly to the assumed statement of the writer that the orebearing solutions descended directly and exclusively from the overlying White porphyry, inasmuch as his own observations show that on Fryer Hill, where he had been in charge of an important mine, the ore bodies do not occur exclusively or predominatingly on the upper contact of limestone with porphyry, and that they appeared

a Loc. cit., p. 584.

Sulphide deposits of South Iron Hill: Trans. Am. Inst. Min. Eng., 1885, vol. 14, 1886, pp. 181-189.

c The Leadville ore deposits: Ibid., 1885, vol. 14, 1886, pp. 273-292.

The geology and ore deposits of Iron Hill: Ibid., 1889, vol, 18, 1890, pp. 145-181. 
to have a closer genetic connection with the Gray than with the White porphyry. His general statement with regard to the deposits of the district, however, is as follows: ${ }^{a}$

They are found mainly as contact deposits between the Carboniferous limestone and the overlying felsite, with additional or incidental ore accumulations in the limestone in irregular cavities, directly or indirectly connected with the plane of contact by irregular and often minute conduits, which a careful search reveals.

This statement, as far as it goes, is a confirmation of that of the writer.

In a subsequent article in the same periodical ${ }^{b}$ the writer has pointed out how far the apparent discrepancy of their views arose from a misconstruction, on the part of Mr. Rolker, either of his statements or of the facts.

Mr. Blow's article, based as it was on nine years' continuous observation of the practical extraction of ore in a part of the region where the ore bodies have been deposited to a considerable extent along vertical fractures as well as on the more or less horizontal contacts and bedding planes in the limestone, constituted an invaluable contribution to the geological history of Leadville ore deposits, and his conclusions from actually observed facts, such as the origin of manganese in the oxidized ores, and of secondary enrichment, especially of zinc in the upper part of the sulphide bodies, showed remarkable acumen in observation and reasoning. The more theoretical part of his article, relating to what the writer would have called the ultimate source of the metals, is, however, less satisfactory, because, while professedly intended as a refutation of the writer's views, it starts with a misconception of those views, and also because it brings no observed facts to support those which he proposes as a substitute for them.

The misconception consists, first, in his failing to appreciate the fact that the writer was speaking only of the immediate source and declined to discuss the ultimate and theoretical source, and, second, in his mistaken assumption that the writer stated that the metals were derived from the White porphyry. The main part of his argument is devoted to the refutation of this latter mistaken assumption, and is purely negative; but, when he comes to his positive assertions, he simply gives as the alternative source the word "below." the use of which the writer had deprecated because of its indefiniteness; and as to the manner in which the solutions reached the present locus of the ore bodies, or what the writer would have called the immediate source, he says: ${ }^{c}$

2. That such ascending solutions more readily penetrated the limestone along the planes of contact of the igneous and sedimentary formations, and through zones of lest

a Loc. cit., p. 282.

b Genesis of certain ore deposits: Trans. Am. Inst. Min. Eng., 1886, vol. 15, p. 125,

c Trans. Am. Inst. Min. Eng., vol. 18, 1890, p. 174, 
resistance in the lattęr previously marked out by the intrusion of the porphyries, and gradually replaced the limestone with their metalliferous contents in the form of sulphides.

The writer, in seeking for reasons for the location of the majority of the ore bodies in the Blue limestone, states: ${ }^{a}$

The great intrusive sheets of porphyry are found to follow it most persistently, mainly along the upper surface, less frequently along its under surface, and also cutting transversely across it. These intrusive bodies are also found at other horizons, it is true, but at none so persistently and so uniformly as at this. Thus both ascending and descending currents would readily reach these beds, the latter trickling through the uniformly permeable eruptive rock, the former following up the walls of the channels, through which it was erupted.

Thus, taking into consideration the greater development of ore bodies and intrusive sheets of Gray porphyry which had been shown to exist at the time Mr. Blow wrote, the difference in view between him and the writer is not essential, for he does not bring any facts to bear against the latter's third reason for declining to accept upward currents as the direct source of the ore, ${ }^{b} i$. e., "the noticeable absence, in the region of greatest ore development, of channels extending downward, through which the ascending solutions might have comë." Indeed, in his descriptions he speaks of the ores as going downward rather than upward, and when they occur along vertical fractures he does not suggest their continuation below the Blue limestone, but simply argues against their immediate derivation from the overlying White porphyry, and is apparently no more a believer in Mr. J. Alden Smith's theory than was the writer. Yet the region he treats of is the one region in Lead ville where vertical cracks are most frequently found n connection with ores in limestone; and it is upon their occurrence that Mr. Blow founded his theory of northeast shoots as the prevailing orm of Leadville ore bodies. Hence, the assumption of the various reatises on ore deposits that the writer's theory as to the source of the metals has been disproved by Mr. Blow seems to have been iounded on an unfortunate misconception of the facts.

On the other hand, with regard to the ultimate source of the metals, $t$ does not appear from his text that Mr. Blow is entirely clear in his nind as to what that source was, or as to the process by which the rein minerals were derived from it. In one place he says ${ }^{c}$ that "it loes not necessarily preclude the theory that the porphyries were the lerivative rock mass from which the ascending solutions receive their netallic contents, ${ }^{*} * *$ to be ejected subsequent to the porphyies, and consequent upon their intrusion;" and later that the "soluions were forced up with their mineral contents from the deep, from

a Mon. U. S. Geol. Survey, vol. 12, 1886, p. 541.

$b$ Ibid., p. 573.

c Tirans. Am. Inst. Min. .Eng., vol. 18, 1890, p. 181.

Bull. $320-07 \longrightarrow 5$ 
the same regions and in the same manner as that of the intrusive dike porphyries with which they are here and elsewhere so intimately connected." .Mr. Blow frankly agrees with the writer, however, in admitting that the theory that the solutions came from below is not susceptible of direct proof; hence, the real difference between him. and the writer is that the one was willing and the other was unwilling to put forward views in support of which he could bring no facts of observation.

\section{MODERN VIEWS ON ORE DEPOSITION.}

In more recent times, as the knowledge of ore deposits, through scientific studies, has increased, and the more theoretical questions with regard to them have become frequent subjects of discussion, many important changes have been brought about in the views generally held with regard to the origin and manner of formation of ore deposits. It has been actually demonstrated:

1. That deposits in limestone have been formed by directly ascending solutions, of which those of Rico, Colo., are the most notable instances.

2. That certain deposits in limestone have been formed primarily by direct emanations of mineral-bearing solutions from intruded igneous masses during cooling and consolidation, to which alone the term contact deposits is now considered to be scientifically applicable, since they are characterized by the presence of minerals formed during what is known as contact metamorphism. Up to 1901 there were no published scientific descriptions of such deposits in the United States, but since that time a vast number of important deposits, especially of copper, have been described as properly belonging to this type.

3. That certain deposits, especially of magnetic iron, have been actually formed by magmatic segregation from igneous masses during their cooling and consolidation.

4. That underground waters, which are still regarded as the most important vehicle for the transportation of vein material within the earth's crust, are not necessarily all of meteoric origin, as was formerly thought, but may rise from the squeezing out of occluded water from igneous magmas as they cool and contract. That such magmas are giving out water in sufficient quantity to feed thermal springs or to form ore deposits is of course not susceptible of direct proof. It has long been recognized that during volcanic eruptions great quantities of the vapor of water escaped into the atmosphere, but this phenomenon has hitherto been explained as the result of the descent through fissures of ocean waters that came into contact with the rising magmas and thus produced extensive eruptions. Suess, the most prominent advocate of the modern theory, claims that it is not the ocean that feeds volcanoes, but that volcanoes have furnished water to 
the ocean. Indirect arguments in favor of this theory are found, first, in the observed fact that in very deep mines the lowest levels are relatively or absolutely dry; whence it is assumed that if surface waters do not reach such comparatively shallow depths they can hardly be supposed to have been the vehicle which brought the metals up from the barysphere, which must be fifty or a hundred fold as deep, or even to have reached any very deep-seated cooling magma. Second, European geologists, who have been making very long and thorough chemical studies of thermal waters, claim to be able to distinguish among them, by the relative permanence of their chemical composition and degree of saturation, those which are fed exclusively by cooling magmas, or what Suess calls juvenile waters, from those which are fed exclusively from meteoric waters, or vadose springs, or, again, those which are fed in part from one and in part from the other source.

5. Finally, it is generally admitted that the ores as now found in an ore deposit may be the result of a solution and reprecipitation many times repeated, each process resulting in a concentration of its metallic contents. Most important of these, from an economic view, is the secondary enrichment by surface waters. This was noted by the writer in his original report, as applied to the oxidized ores, but it was not then supposed to be possible chemically that it might go on below the ground-water level in the sulphide zone. This has recently been demonstrated, however, by actual laboratory experiments, and the action is recognized as the most important factor in forming the bonanzas of exoeptionally rich deposits.

\section{PRESENT VIEWS OF GENESIS OF LEADVILLE LIMESTONE ORES.}

It may be assumed that economic geologists now generally agree, without much qualification, that the limestone ores in the Leadville district were originally deposited-

1. From aqueous solutions.

2. In the original form of sulphides:

3. By metasomatic replacement of the country rock.

Age.-These ores were deposited after the porphyry sheets were intruded and consolidated, but before the dynamic movements which produced the great structural faults of the region. Geological investigations made since the original report was prepared have led to the conclusion that the great preliminary fault movement may have taken place at the close of the Jurassic period, or previous to the beginning of Cretaceous sedimentation, and inasmuch as it must logically be assumed that the structural faulting in the Leadville district was contemporaneous with that of the Mosquito fault the ores in limestone may have been originally deposited in pre-Cretaceous time. 
It is further recognized that a small amount of deformation of the sedimentary beds must have taken place at the time of the intrusion of the porphyry sheets, which produced some slight folding and fracturing of these beds, and thus commenced the localization of the ore bodies.

That there has been movement in comparatively recent times along the great structural faults, as was originally stated, has now been definitely proved. Underground exploration has shown that the comparatively recent rhyolitic tuffs and agglomerates are much more widespread in the district than was indicated on the original map. They have cut through and split important ore bodies, but have apparently been confined to the region around Breece Hill, and have not affected the limestone deposits in the lower part of the district.

Distribution of ore.-It was originally assumed, on evidence then available, that the Blue limestone was exceptionally favorable to the deposition and concentration of ore, but it was also stated ${ }^{\circ}$ "that valuable deposits are occasionally found elsewhere, generally along bedding planes or contact surfaces, and less frequently on jointing planes."

Mining developments since that time have shown that the predominance of ore bodies along the upper contact of the Blue limestones is by no means so great as was originally supposed, some of the most important ore shoots having been found within its mass at points away from that contact, generally under the sheet of Gray porphyry, but also within the mass of the White limestone. These are locally called second- and third-contact bodies, respectively. Ore bodies also occur within the Parting quartzite and in the upper part of the Cambrian quartzite. No important and rich ore deposits have been found, however, within the purely siliceous beds at the lower part of the Cambrian, nor at the contact of the latter with the crystalline complex or Archean, such as J. Alden Smith thought would "be extensively and profitably worked for centuries after the contact deposits now operated would be exhausted."

It should be further remarked that the important deposits of gold ores in and adjoining fissure veins in the Breece Hill region are not included in the present discussion, which is confined to the limestone ores treated of in the original report, since their genesis is considered to be distinct and more or less independent of the latter, and will be discussed at length in the general report.

As regards the areal distribution of the principal ore bodies, it bears an evident connection with that of the later intrusive or Gray porphyry sheets, the details of which can not be finally worked out 
until the general geological map of the district is finished. It would appear at present, however, that where these intrusive bodies have distinctly broken up from below, across the sedimentary beds, as have those that form the mass of Breece and Dome hills, the ores in limestone tend to form around the periphery of such masses.

Immediate source of the metals.-In considering the source or origin of the metallic contents of the ore it seems well to preserve the distinction originally made by the writer between the immediate and ultimate sources, although this distinction has been ignored by subsequent writers. General treatises can not go into the minute details of structure involved in a consideration of the immediate source, but must be confined to the broader features in their bearing on general theories. Moreover, few, if any, "of their authors have ever visited this district, much less made detailed studies of the geological relations of its deposits. On the other hand, the mining engineers, whose opportunities of studying the details of the ore bodies that come under their observation were unquestionably much superior to those of the writer, not being professional geologists and having worked in a relatively limited field, may not have noted the bearing on general theories of all the geological facts that came under their observation.

The determination of the immediate source of the ores is important, even though it may not necessarily affect that of the ultimate source, inasmuch as it furnishes data of practical use to the miner in his search for ore. Thus, in the present case, it would appear that the conception of the authors of general treatises who maintain that the ores were brought in by hot ascending solutions from some deepseated source is that in their upward course these solutions were stopped by a relatively impermeable barrier, in this case the overlying parphyry sheets, and hence spread out laterally, depositing their contents in the limestone underlying these porphyries. In such a case one would expect to find cracks or fissures extending more or less vertically downward from the respective ore bodies which might have constituted the channels through which the solutions ascended directly to the porphyry contact.

On the other hand, if the ore-bearing solutions, in the latter part of their circulation or immediately before they deposited their contents in the form of the present ore bodies, were moving along the contact planes between porphyry and limestone, they could react on the soluble limestone from these contacts outward and form ore bodies, either along the immediate contact or at points within its mass, reached through cracks and joints. On this hypothesis, if most of the contact ore bodies were found under the porphyry sheet, the prevailing course of the ore solutions would have been downward, and such 
solutions might have formed ore bodies on the upper contact of a lower sheet, because that sheet presented a barrier to their downward course.

As regards the ultimate source of the ores, while the former of these hypotheses is more peculiarly applicable to the deep-seated source, the latter is not inconsistent with the derivation of the metals from either the barysphere or from igneous masses within limited distances of the ore deposits.

Leaving entirely out of consideration, for the moment, the question of the ultimate source of the metals, the evidence as to their immediate source must first be considered, since, from the whiter's point of view, that is the only one really involved in the criticisms of his original report. In favor of the first, or what might be called the "fissure hypothesis," is the discovery in recent years of deposits coming from or directly connected with vertical fissures in the Breece Hill region, which, however, according to the writer's view were formed in a distinct and different manner from the deposits in limestone in the lower part of the district, which are now under consideration. In the latter deposits the writer has been unable to find evidence which seems to him conclusive in favor of the fissure hypothesis, or which might not be as readily interpreted in favor of contact and stratification planes as channels for the ore-bearing solutions. Cracks and broken or fissured zones are, it is true, found in connection with some of the limestone ore bodies, especially with ore bodies that have a decided linear arrangement, such as the ore shoots on South Iron Hill, described by Blow. In a broad, general way, these shoots lie in two prominent or major directions - a northwest-southeast direction, which prevails on Iron and Breece hills, and an east-west direction, which is more prominent in the northwest portion of the district. These apparently correspond to those of the axes of slight folding and fracturing that took place about the time of the intrusion of the porphrm. The structural conditions accompanying these fissures do not resemble however, those connected with the limestone deposits of Rico, Colo., which may be taken as the type of those formed by solutions that ascended through fissures. At Rico the feeding fissures contain well-defined and crustified vein deposits. They end upward at a bed of impervious shale that overlies the limestone, but no limit in depth has yet been found. Under the shale, ore bodies called "blarkets" spread out horizontally in the limestone, following a zone that is at some places brecciated along the general direction of the fissures It has been generally assumed in this case that the ores in the blanket deposits were deposited by waters ascending along the fisures, but Ransome, who made the latest and most detailed study of the district. thinks they are due to the mingling of these with solutions that moved laterally along the blanket zone. 
In the Leadville limestone only small cracks have been observed in connection with the ore bodies. Many of these cracks are traceable upward from the tops of the ore bodies to the overlying porphyry, but, so far as known to the writer, do not extend downward much below the workable ore bodies. A similar conclusion might be drawn from Mr. Blow's description of the Iron Hill ore bodies, for when he prophesies that their extension will be found at a lower horizon, he expects them to go down not vertically but transversely across the stratification, and, as stated above, he believes that the ore solutions entered the limestone along the contacts of Gray porphyry sheets. His improper use of the word "dike" to denote crosscutting sheets has given rise to the idea that he supposed the solutions to have risen vertically along actual dikes to the present ore bodies.

It is evident that the fractures that cross the limestone have played an important part in fixing the location of ore bodies and in furnishing channels along which the ore-bearing solutions may pass from one horizon to another, but the general impression produced upon the mind of the writer has been rather that they served to divert or temporarily to arrest horizontally moving solutions (especially where, as can sometimes be proved, they are the final result of a strain that produced folding) rather than afforded continuous channels for solutions moving directly upward.

The relative superposition of ore bodies at different horizons in a given region is, furthermore, such as to suggest that they were formed by solutions that circulated along contacts and bedding planes, and, incidentally, in joints and cracks that crossed the latter, rather than directly upward through a common vertical fissure that fed a series of superposed ore bodies.

There is, moreover, an absence of evidence in the mineralogical composition of the ores and wall rocks that these ore-bearing solutions had temperatures that were high enough to render their direct upward course inherently probable.

Ultimate source of the metals.-The writer does not consider it appropriate in this place to go at length into the theoretical question of magmatic versus meteoric waters, which has been abundantly discussed of late in special articles and treatises, an increasing importance being given by many of our best students of ore deposits to the agency of magmatic waters in the formation of ore deposits which may be genetically connected with igneous eruptions. It seems better to postpone the discussion of the broad question of the ultimate origin of the metallic contents of the Leadville ore deposits until the map of the whole district shall have been completed rather than to attempt it in connection with the present description of a comparatively small portion of the area, in which the oxidizing agents have obscured much of the evidence. The original contention that 
the ores are genetically connected with the eruptive rocks seems abundantly confirmed and even strengthened by the development of the last twenty-five years. That their concentration in exceptionally rich bodies has come about through the agency of surface waters is also confirmed, and the study of the sulphide bodies has shown that this secondary enrichment has not been confined to the oxidized zone, but has extended below the ground-water level. The questions still at issue are:

1. Whether the sulphide ores were originally deposited as a precipitate exclusively from meteoric or from magmatic waters, or in part from both.

2. Whether the magmatic waters, if they were the transporting agents, reached the present locus of the deposits directly from below, or whether they came up along the general channels that carried the magma of the intrusive rocks, and, where this magma had spread out in sheets between the sedimentary strata, whether they followed in general the contacts between intrusives and sedimentaries or pentrated the mass of the latter along cracks and joints before depositing their load.

3. Whether the deposits, or any part of them, were formed by contact metamorphism - that is, by waters emanating directly from the cooling intrusive bodies, squeezed out, as it were, from the solidifying igneous mass into the adjoining sedimentary beds. 


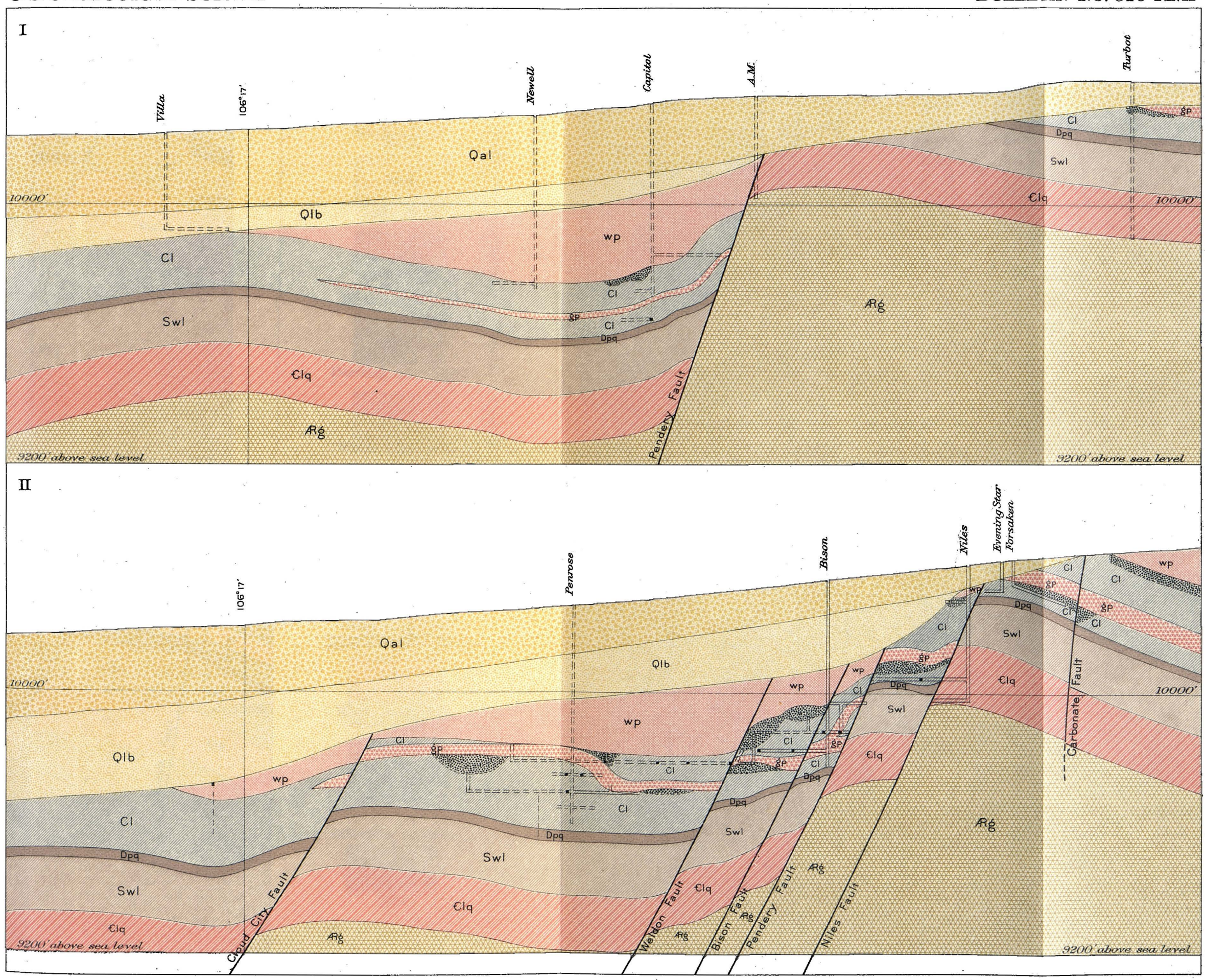

LEGEND

SEDIMENTARY ROCKS

\begin{tabular}{|c|}
\hline Qal \\
\hline Wash \\
\hline Q16 \\
\hline
\end{tabular}

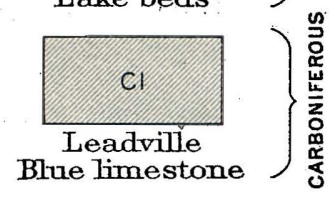

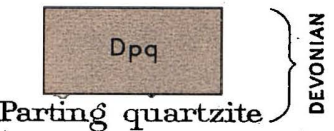



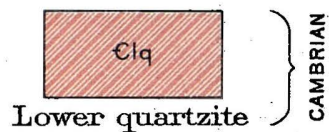

Lotrer quartzite o

IGNEOUS ROCKS



ECONOMIC GEOLOGY



Ore

SECTIONS ON LINES I AND II, PL. I

Vertical and horizontal scale

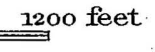




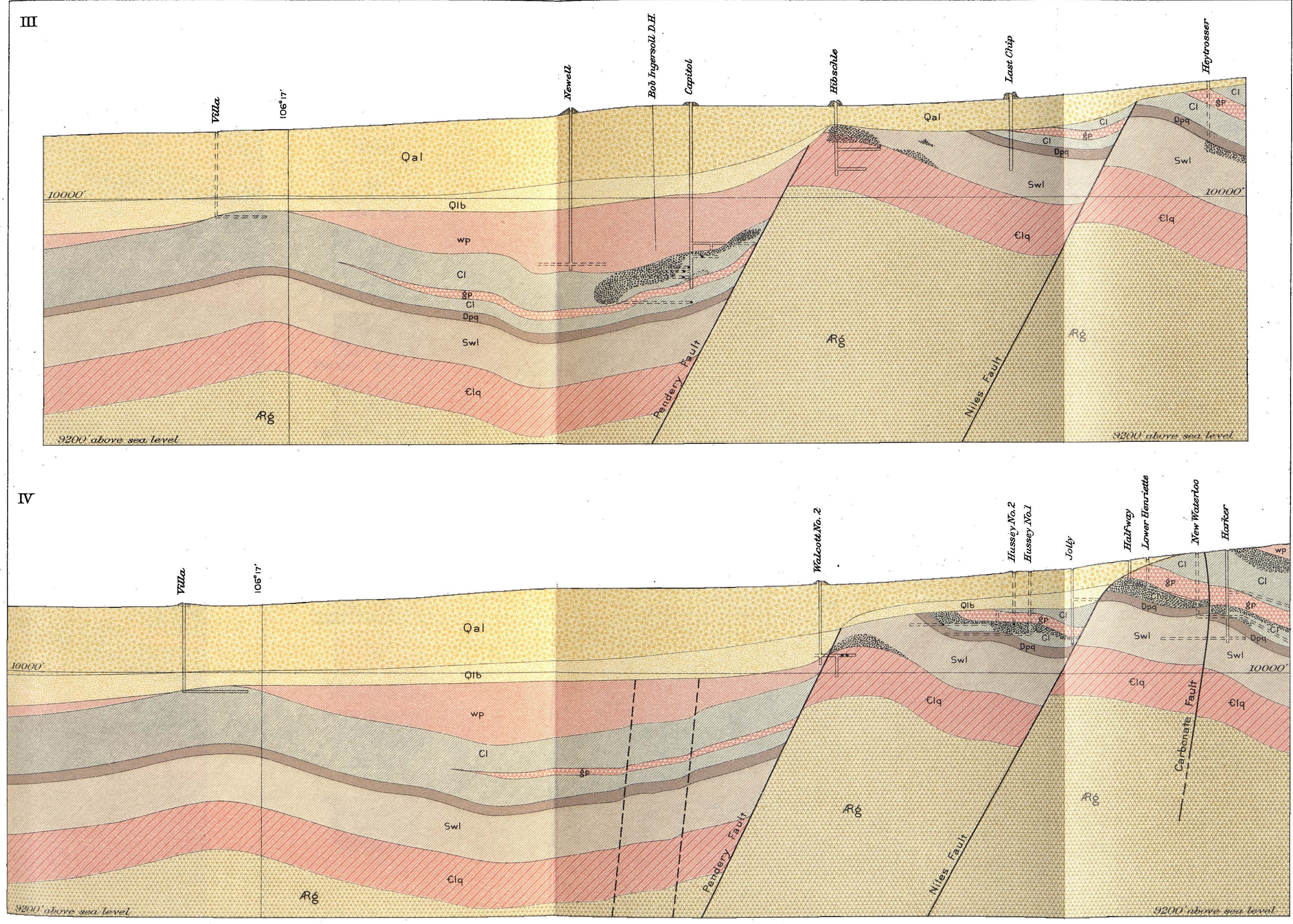

SECTIONS ON LINES III AND IV, PL. I

Vertical and horizontal scale 



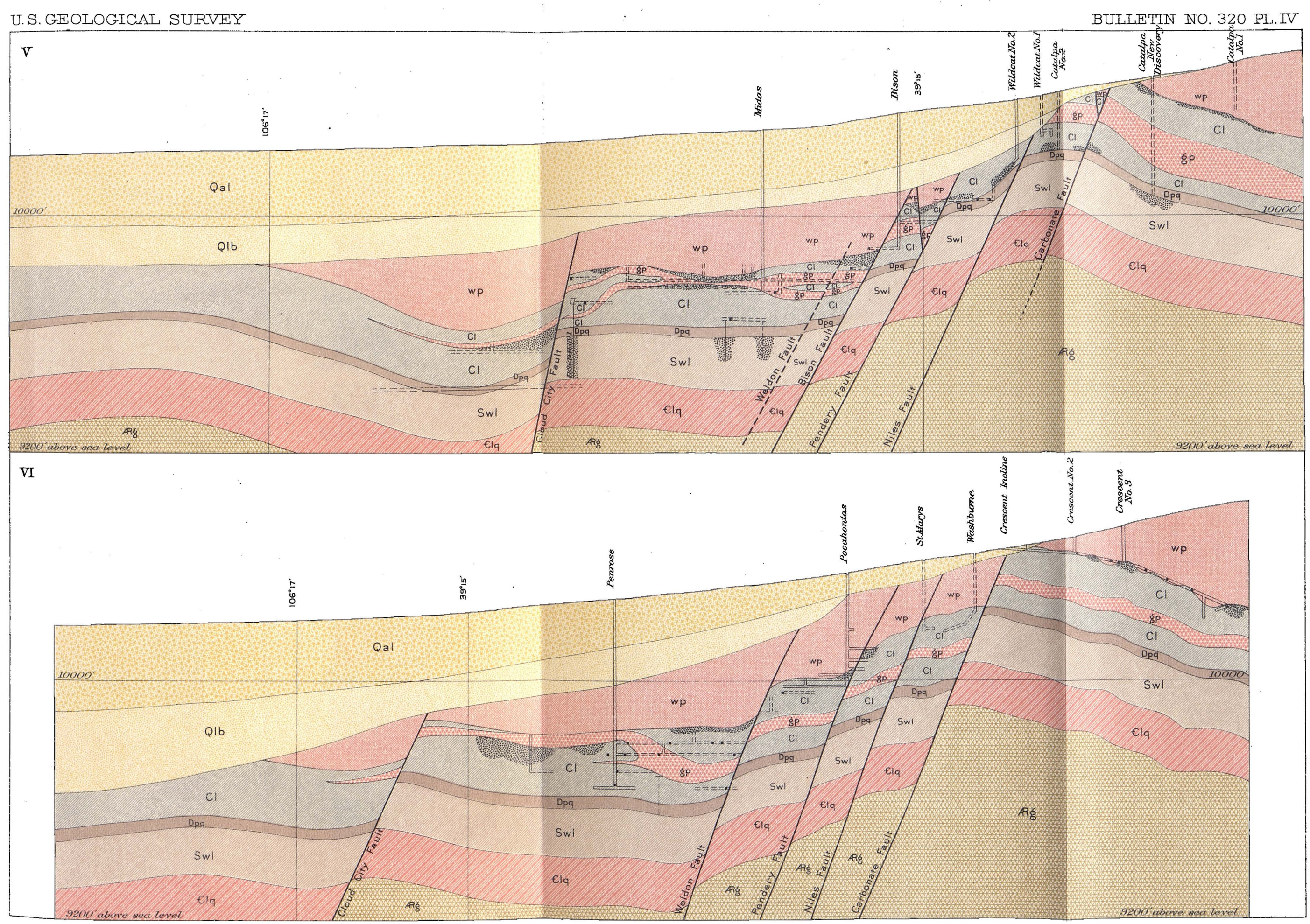

BULLETTIN NO. 320 PL.IV

SEDIMENTARY ROCKS

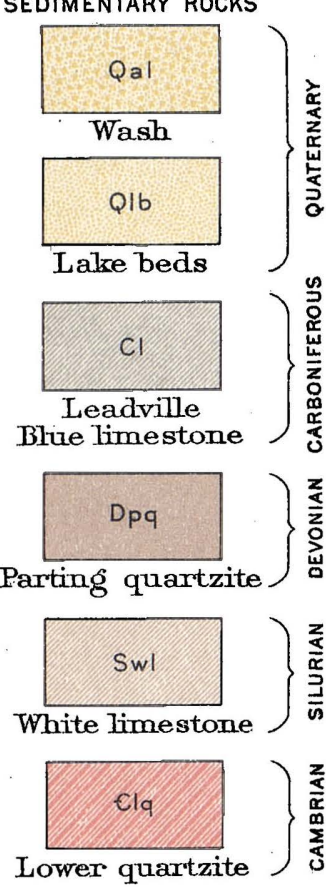

IGNEOUS ROCKS

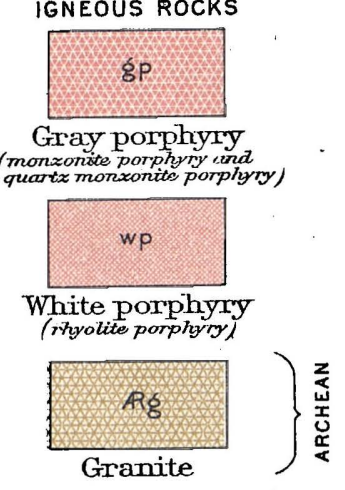

ECONOMIC GEOLOGY

SECTIONS ON LINES V AND VI, PL. I

Vertical and horizontal scale 



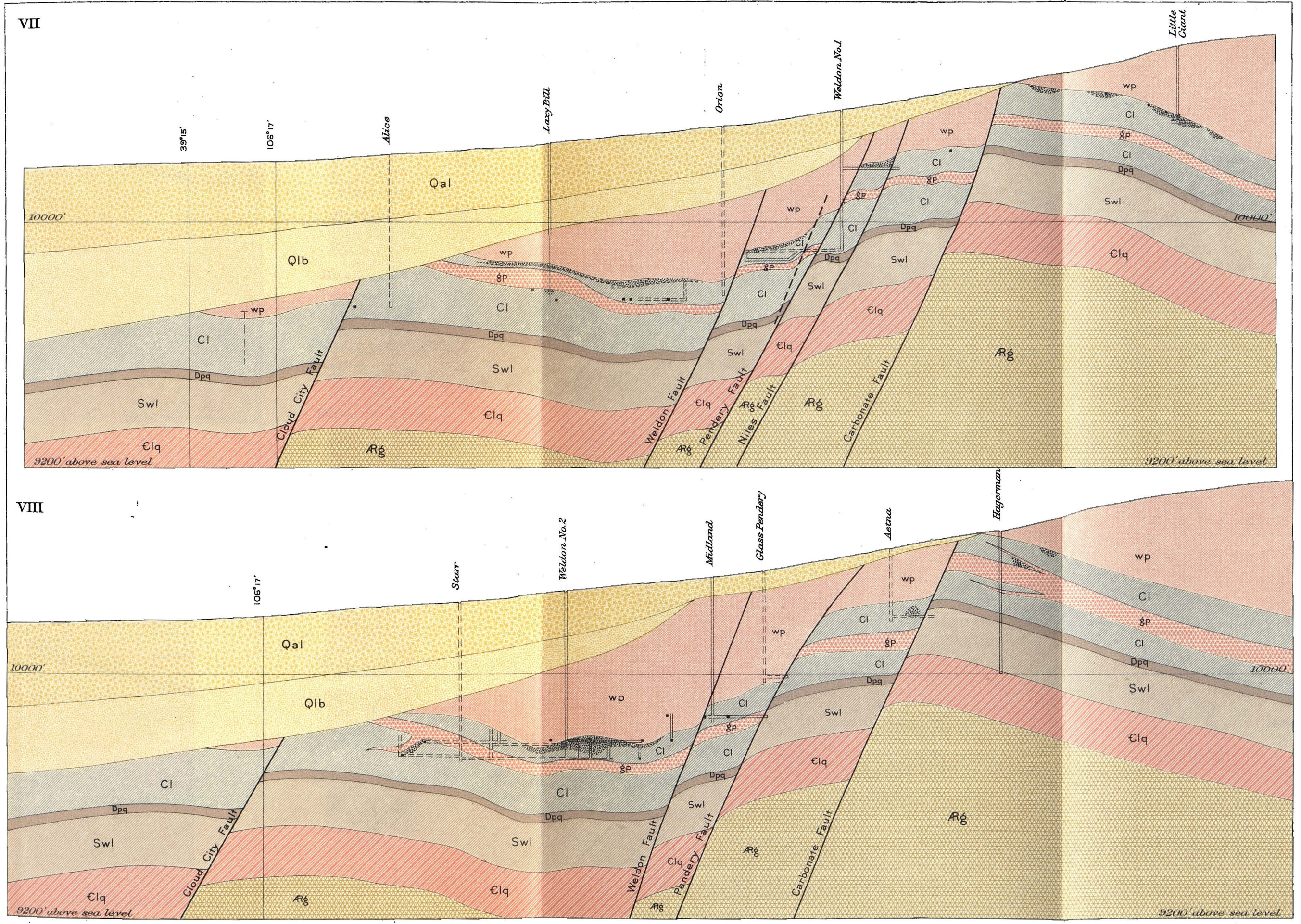

LEGEND SEDIMENTARY ROCKS

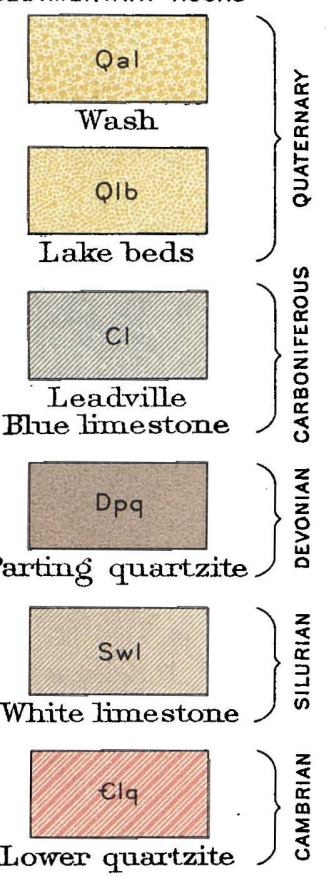

Lower quartzite

IGNEOUS ROCKS

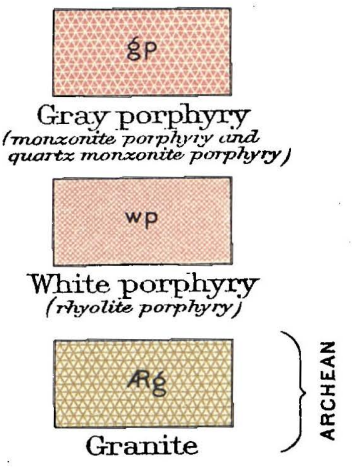

ECONOMIC GEOLOGY

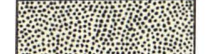

$\frac{1.7 x}{\text { Ore }}$ 



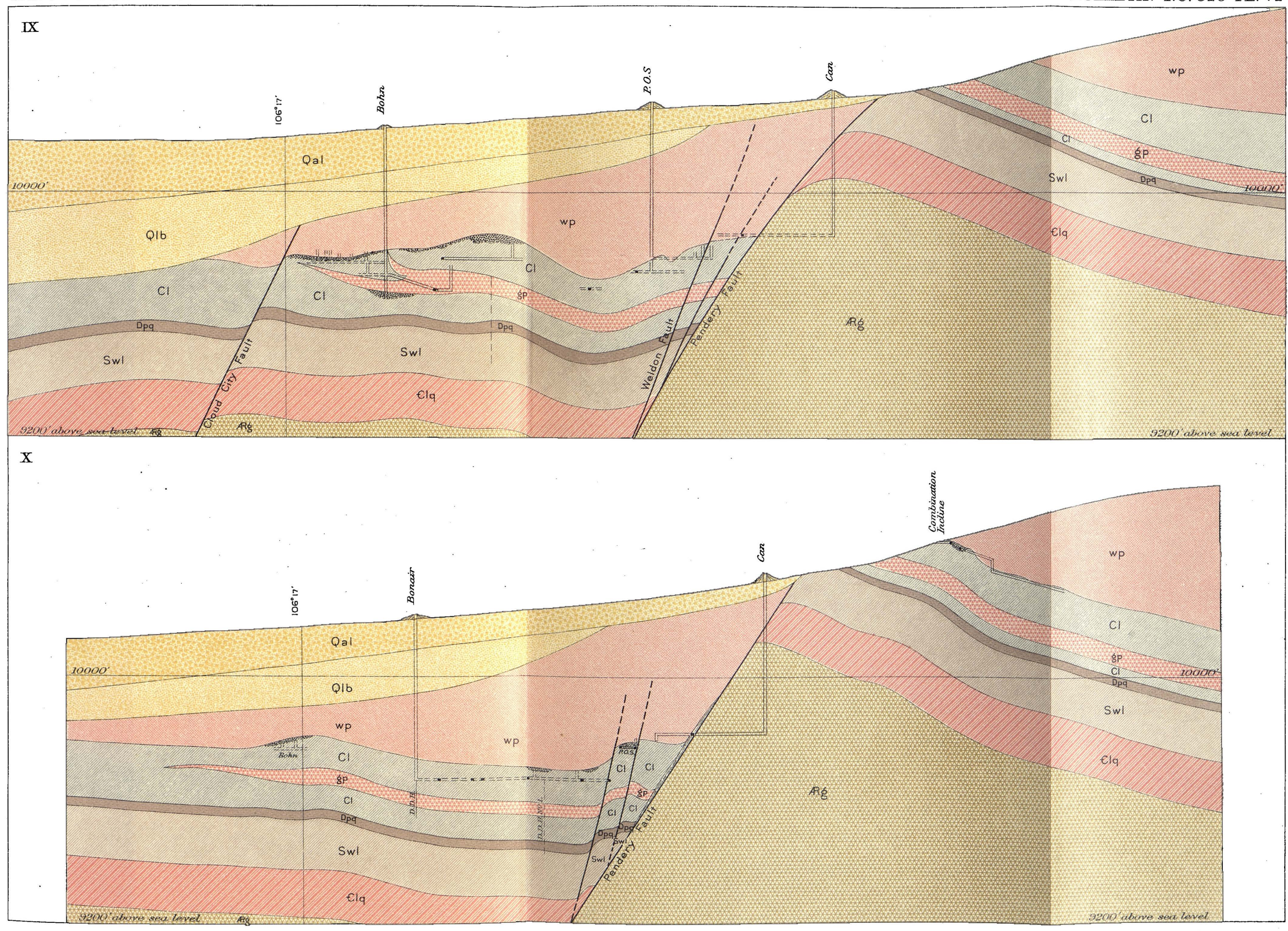

LEGEND SEDIMENTARY ROCKS

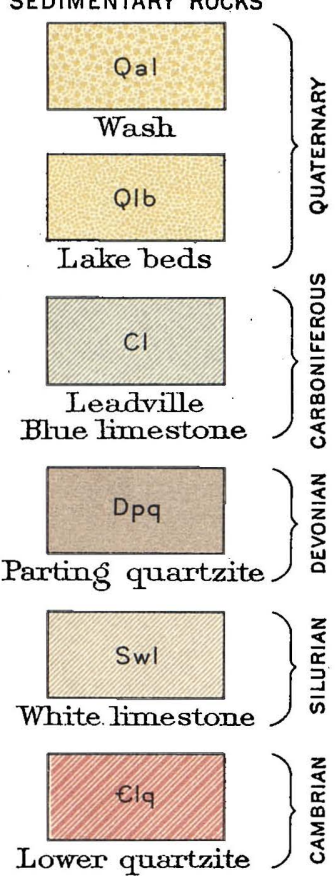

Lower quartzite

IGNEOUS ROCKS

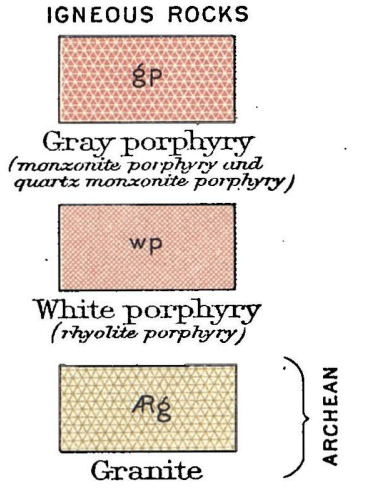

ECONOMIC GEOLOGY 



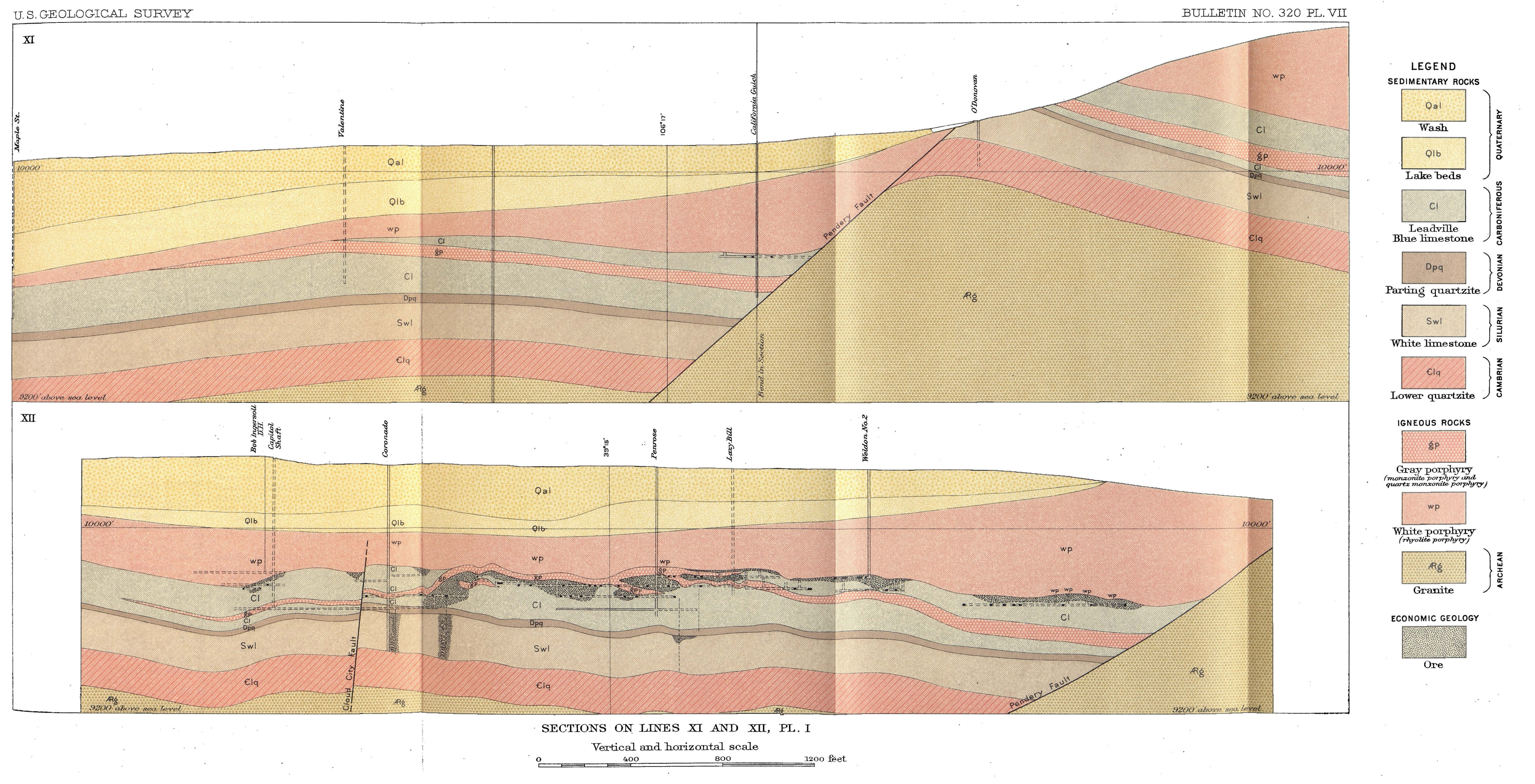





\section{INDEX.}

A.

Atna mine

Page.

28

Alice shaft _.

All Right shaft _._._._._- 25, 43-44

Arkansas River, glacial history of -. 11

Ascending solutions, ore deposition by-_-_- 60-72

A. V. shaft

\section{B. .}

Bison fault, description of

29

1.Bison shaft _-

Blow, A. A., on ore deposition _- 64-66

Blue limestone, disintegration of --- 47 intrusions in . 9 occurrence of ores in _.._. position of _..

Bob Ingersoll drill hole

Bobn shaft _._.

Bon Air mine_._._._._._. 23, 25, 55

Breece Hill region, ores of _._._. 68,69

- Buckeye Belle shaft

C.

Cady shaft

California Gulch shaft

16

California tunnel

Can mine workings of, figure showing _-_ 56

Capitol mine_._.

Capps, S. R., and Leffingwell, E. D. K., on glacial deposits _........-.

- Carbonate fault, description of -.. development below

Carbonate Hill, ore development on ores of

rock series at

section of -

Carbonate mine

Catalpa mine_-_._. 24, 37

Chrysolite mine (Clark shaft) -..-_- 24, 42

Cloud City fault, description of -.. 23, $29-30,46,53$

(Cloud City shaft_- 19, 23, 29, 30, 46, 52, 53

Contact, The, definition of

Colorado Chief No. 2 shaft_-_- 24, 31. 42 Coronado mine _....... 23, 25, 32, 45, 46-47 Crescent claim
D.

Davis, W. M., on lacustrine beds 12 Delante shaft Descending solutions, ore deposition by Dillon mine Dolomite sand, description of -...- 47 Dome Hill, Lake beds on

\section{F.}

Earthy minerals, occurrence of Economic deve!opment, condition of $-23-26$ history of Elk mine Empire Gulch glacier, extent of _..- 19 Enrichment. secondary, process of $\quad 67$ Eruptive rocks, ores derived from $-60-62$. 71-72 Evans glacier, extent of
Évening Star mine Évening Star mine $25,37-38,39$

\section{F.}

Fairview No.' 4 shaft $24,43-44$

Fault blocks of $7-10$

Faults, components of $26-27^{\circ}$ . distribution of _._._._-_ 9, 27-30 See also particular faults.

Flood, origin of term

Forsaken shaft...... 21-39

Forest City claim, ore in

Freeland, F. 'T., on ore deposition _.. $\quad 63$

Fryer Hill, development on ores of

\section{(r.}

Gangue, character of Geologic map of district_._._._-_. Pocket. Geologic sections, plates showing -- 72 Geology, descriptive -.-_-_-_-- 6-20 Geology, structural. See Structure.

Glacial epochs, occurrence of two, proof of _._._. $11,12,13$

Glașs-Pendery shaft

Gold in Leadville ores, occurrence of $\quad 34$ Graham Park, Lake beds in Gravel beds. Sce Lake beds.

Gray Eagle mine _......... 22, 25, 29, 49 Gray porphyry, occurrence and character of _._. $24,30-31$, passim $37-59$ Greenback shaft, ore in _....... 15, 43 
INDEX.

H.

Harker shaft

Irenrietta mine (Halfway House 28, 38

Hibschle mine shaft) _._._._._. 37, 39

Home Extension shaft

liope shaft

Hussey mine

I.

Ida Nyce shaft

Igneous rocks, derivation of ores from

Iowa Gulch glacier, extent of _._- 19 Iron in oxidized ores, occurrence of

J.

Jason shaft

43

Jolly shaft

$24,25,28,41$

I.

Isacustrine beds, so-called, differentia-

$$
\text { tion of }
$$

Lake beds, character of

deposition of

16

distribution of _._._._-_ 8, 11, 11-16

faulting of

origin of _._.

uplift of, since deposition

Lake Creek, glacier 110m__._._-_ 11, 15-16

Last Chip shaft

Lazy Bill shaft, ore-shoot under --_ $\quad$ 51

Lead, oxidized ores of _._._._._. $\quad 33$

Leadville limestone. Sce Blue limestone.

Leffingwell, E. D. K., and Capp. S. R., on glacial deposits..--

Little Giant mine

\section{II.}

Magmatic water's, ore deposition by _.

Maid mine__._. 28,38

Manganese, relative proportion of, in sulphide and oxide ores - _._-

Map, geologic, of district _... I'ocket. Maple Street shaft _._._.__ 18, 25-26,31 May Queen. shaft

Metals-

immediate source of

$69-71$

ultimate source of

Midas-Penrose ground, ores in $23,30,48-51$

Midland mine, workings of, fgure

showing -

Modoc shaft

Morning Star mine

Mosquito fault, losation and char-

Mosquito glaciers, position of

Iosquito Range, geologic structure of
N.

Page.

Neptune shaft
Newell shaft

Newell shaft___.

Niles fault, description of _._._-_ 28

Northern mine _._. 23, 25, 4j

o.

Ores, age of composition of _._-_._._._. 31-32 distribution of _. genesis of _..._. geologic position of _........... 31-32 oxidation of _. source of _..._. Oxidation, methods of

P.

P. O. S. mine______ 29, 55-56,57,58 ore body of, section of, figure showing _........- 58 workings of, figures showing _. 56,57

Parting quartzite, ores in _._._._. 68

Pendery fault, description of ---- 27-28, 40 development below _.........

Penrose mine _..._- 23, 25, 30, 32, 48, 49, 50

Pocahontas mine -

Porphyry, genetic connection of ores with

62

Prospect incline, fault at

Pumping, necessity of

\section{Q.}

Quaternary deposits, distribution and character of

R.

R. A. M. shaft

Ransome, F. L., on Rico ores... 70

Reindeer shaft

fault at

Rialto shaft _.

Ricketts, L. D., on ores of Carbonate Hill _. 37

Rico, Colo., ores of

Rock Hill, Iake beds on

Rolker, C. M., on Leadville ore deposits___._. $63-64$

S.

St. Mary shaft

Sawatch Range, rocks of

Second-contact ores, definition of term nccurrence of $40,41,46,47,48,50,3$

$6-7,11$ Sections, geologic, plates showing -- 
Seelcy shaft

Pag?.

Seneca shaft

23,45

Shamrock mine

Silver In oxidized ores

Sixth Street shaft_._- 19, 23, 25, 30, 32, 47

Bmall Hope Mining Company, ore or

43

Smith, J. A., on genesis of ores_ $61,65,68$ Solutions, ascending and descending, ore deposition by

South Iron Hill, ores of ___

Starr and Cloud City. mines, ores In section through, figure showing - -...-...-.

Step faults, occurrence of

Stumph shaft

Gulch depression, ores in 24,

Strike of 1896 , result of $24,39-41$

Structure, geologic, description of ---

Suess, E., on magmatic water

T.

ITerraces in Arkansas Valley, occurrence and description of -

Thespian shaft ores, definition of Third-contact ores, definition of term

36,68

position of

Toledo Avenue shaft, fault at

Turbot shaft

Twin Lakes, glaciation near
U.

Page.

Upper-contact ores, definition of term -

v.

Valentine shaft $25,31,60$

Villa shaft $25,45-46$

w:

Walcott mine

Wash, use of term origin of..... 12,17

Washburn shaft

Water, pumping of

Waterloo mine

Weldon fault, description of

Weldon mine__._. $23,28,29,53-54$

Westgate, L. G., on Twin Lake area $\quad 13$

White limestone, ore in stratigraphical position of _-_-- 21

White porphyry, character of _._- 21 distribution of _._._-_ 20-21, 24, 39 occurrence of _..._... Passim, 37-58 ores below

Wildcat faults, description of

Wolftone mine _..._. 28,38

$\mathbf{Y}$.

Yankee Doodie mine

Ypsilanti mine _... 40

Z.

Zinc, oxidation of - 



\section{CLASSIFICATION OF THE PUBLICATIONS OF THE UNITED STATES GEOLOGICAL SURVEY.}

[Bulletin No. 320.]

The publications of the United States Geological Survey consist of (1) Annual Reports, (2) Monographs, (3) Professional Papers, (4) Bulletins, (5). Mineral Resources, (6) Water-Supply and Irrigation Papers, (7) Topographic Atlas of United States-folios and separate sheets thereof, (8) Geologic Atlas of United States-folios thereof. The classes numbered 2, 7, and 8 are sold at cost of publication; the others are distributed free. A circular giving complete lists can be had on application.

1 Most of the above publications can be obtained or consulted in the following ways:

1. A limited number are delivered to the Director of the Survey, from whom they can be obtained, free of charge (except classes 2, 7, and 8), on application.

2. A certain number are delivered to Senators and Representatives in Congress ior distribution.

3. Qther copies are deposited with the Superintendent of Documents, Washington, J. C., from whom they can be had at prices slightly above cost.

4. Copies of all Government publications are furnished to the principal public ibraries in the large cities throughout the United States, where they can be conulted by those interested.

7. The Professional Papers, Bulletins, and Water-Supply Papers treat of a variety if subjects, and the total number issued is large. They have therefore been classified nto the following series: A, Economic geology; B, Descriptive geology; C, Systemtic geology and paleontology; D, Petrography and mineralogy; E, Chemistry and hysics; F, Geography; G, Miscellaneous; H, Forestry; I, Irrigation; J, Water storge; K, Pumping water; L, Quality of water; $M$, General hydrographic investigaions; N, Water power; O, Underground waters; P, Hydrographic progress reports. - 'his paper is the hundred and first in Series $A$ and the hundred and twenty-third a Series B, the complete lists of which follow ( $\mathrm{PP}=$ Professional Paper; $\mathrm{B}=\mathrm{Bulle}-$ in; WS =Water-Supply I'aper):

\section{SERIES A, ECONOMIC GEOLOGY.'}

21. Lignites of Great Sioux Reservation: Report on region between Grand and Moreau rivers, Dakota, by Bailey Willis. 1885 . $16 \mathrm{pp} ., 5 \mathrm{pls}$. (Out of stcck.)

46. Nature and origin of deposits of phosphate of lime, by R. A. F. Penrose, jr., with introduction by N. S. Shaler. 1888 . $143 \mathrm{pp:}$ (Out of stock.)

65. Stratigraphy of the bituminous coal field of Pennsylvania, Ohio, and West Virginia, by I. C. White. 1891. 212 pp., 11 pls. (Out of stock.)

111. Geology of Big Stone Gap coal. field of Virginia and Kentucky, by M. R. Campbell. 1893. 106 pp., 6 pls. (Out of stock.)

132. The disseminated lead ores of southeastern Missouri, by Arthur Winslow. 1896. 31 pp. (Out. of stock.)

138. Artesian-well prospects in Atlantic Coastal Plain region, by N. H. Darton. 1896. 228 pp., 19 pls.

139. Geology of Castle Mountain mining district ${ }_{4}$ Montana, by W. H. Weed and L. V. Pirsson. 1896. 164 pp., 17 pls.

143. Bibliography of clays and the ceramic arts; by J. C. Branner. $1896.114 \mathrm{pp}$.

164. Reconnaissance on the Rio Grande coal fields of Texas, by T. W. Vaughan, including a report on igneous rocks from the San Carlos coal field, by E. C. E. Lord. 1900.100 pp., 11 pls. (Out of stock.)

178. El Paso tin depasito, by W. H. Weed. 1901.15 pp., 1 pl. 
B 180. Occurrence and distribution of corundum in United States, by J. H. Fratt. 1901.98 pp., 14 pls. (Out of stock; see No. 269.)

B 182. A report on the economic geology of the Silverton quadrangle, Colorado, by F. L. Ransome. 1901. $266 \mathrm{pp} ., 16 \mathrm{pls}$. (Out of stock.)

B 184. Oil and gas fields of the western interior and northern Texas Coal Measures and of the Upper Cretaceous and Tertiary of the western Gulf coast, by G. I. Adams. 1901.64 pp., 10 pls. (Out of stock.)

B 193. The geological relations and distribution of platinum and associated metals, by J. F. Kemp. 1902. 95 pp., 6 pls.

B 198. The Berea grit oil sand in the Cadiz quadrangle, Ohio, by W. T. Griswold. $1902.43 \mathrm{pp} ., 1 \mathrm{pl}$. (Out of stock.)

PP 1. Preliminary report on the Ketchikan mining district, Alaska, with an introductory sketch of the geology of southeastern Alaska, by A. H. Brooks. 1902.120 pp., 2 pls.

B 200. Reconnaissance of the borax deposits of Death Valley and Mohave Desert, by M. R. Campbell. 1902. 23 pp., 1 pl. (Out of stock.)

B 202. Tests for gold and silver in shales from western Kansas, by Waldemar Lindgren. $1902.21 \mathrm{pp}$. (Out of stock.)

PP 2. Reconnaissance of the northwestern portion of Seward Peninsula, Alaska, by A. J. Collier. 1902. 70 pp., 11 pls.

PP 10. Reconnaissance from Fort Hamlin to Kotzebue Sound, Alaska, by way of Dall, Kanuti, Allen, and Kowak rivers, by W. C. Mendenhall. $1902.68 \mathrm{pp} ., 10 \mathrm{pls}$.

PP 11. Clays of the United States east of the Mississippi River, by Heinrich Ries. 1903.298 pp., 9 pls. (Out of stock.)

PP 12. Geology of the Globe copper district, Arizona, by F. L. Ransome. $1903.168 \mathrm{pp} ., 27 \mathrm{pls.}$

B 212. Oil fields of the Texas-Louisiana Gulf Coastal Plain, by C. W. Hayes and William Kennedy. 1903. 174 pp., 11 pls. (Out of stock.)

B 213. Contributions to economic geology, 1902; S. F. Emmons and C. W. Hayes, geologists in charge. 1903. $449 \mathrm{pp}$. (Out of stock.)

PP 15. The mineral resources of the Mount Wrangell district, Alaska, by W. C. Mendenhall and F. C. Schrader. 1903. 71 pp., 10 pls.

B 218. Coal resources of the Yukon, Alaska, by A. J. Collier. 1903.71 pp., 6 pls.

B 219. The ore deposits of Tonopah, Nevada (preliminary report), by J. E. Spurr. 1903.31 pp., 1 pl. (Out of stock.)

PP 20. A reconnaissance in northern Alaska in 1901, by F. C. Schrader. 1904. 139 pp., 16 pls.

PP 21. Geology and ore deposits of the Bisbee quadrangle, Arizona, by F, L. Ransome. 1904. 168 pp., $29 \mathrm{pls}$.

B 223. Gypsum deposits in the United States, by G. I. Adams and others. 1904.129 pp., 21 pls. (Out of stock.)

PP 24. Zinc and lead deposits of northern Arkansas, by G. I. Adams. 1904.118 pp., 27 pls.

PP 25. Copper deposits of the Encampment district, Wyoming, by A. C. Spencer. $1904.107 \mathrm{pp} ., 2 \mathrm{pls.}$ (Out of stock.)

B 225. Contributions to economic geology, 1903, by S. F. Emmons and C. W. Hayes, geologists in charge. 1904. $527 \mathrm{pp} ., 1 \mathrm{pl}$. (Out of stock.)

PP 26. Economic resources of the northern Black Hills, by J. D. Irving, with contributions by S. F. Emmons and T. A. Jaggar, jr. 1904. 222 pp., 20 pls.

PP 27. A geological reconnaissance across the Bitterroot Range and Clearwater Mountains in Montana and Idaho, by Waldemar Lindgren. $1904.123 \mathrm{pp} ., 15 \mathrm{pls}$.

B 229. Tin deposits of the York region, Alaska, by A. J. Collier. 1904.61 pp., 7 pls.

B 236. The Porcupine placer district, Alaska, by C. W. Wright. 1904.35 pp., 10 pls.

B 238. Economic geology of the Iola quadrangle, Kansas, by G. I. Adams, Erasmus Haworth, and W. R. Crane. 1904.83 pp., 11 pls.

B 243. Cement materials and industry of the United States, by E. C. Eckel. 1905.395 pp., 15 pls.

B 246. Zinc and lead deposits of northwestern Illinois, by H. Foster Bain. 1904.56 pp., 5 pls.

B 247. The Fairhaven gold placers of Seward Peninsula, Alaska, by F. H. Moffit. 1905.85 pp., 14 pls.

B 249. Limestones of southeastern Pennsylvania, by F. G. Clapp. 1905.52 pp., 7 pls.

B 250. The petroleum fields of the Pacific coast of Alaska, with an account of the Bering River coal deposits, by G. C. Martin. 1905.65 pp., 7 pls

B 251. The gold placers of the Fortymile, Birch Creek, and Fairbanks regions, Alaska, by L. M. Prindle. 1905. 89 pp., 16 pls.

WS 117. The lignite of North Dakota and its relation to irrigation, by F. A. Wilder. 1905.59 pp., 8 pls.

PP 36. The lead, zinc, and fluorspar deposits of western Kentucky, by E. O. Ulrich and W. S. T. Smith. 1905. 218 pp., 15 pls.

PP 38. Fconomic geology of the Bingham mining district, Utah, by J. M. Boutwell, with a chapter on areal geology, by Arthur Keith, and an introduction on general geology, by S. F. Emmons. 1905. 413 pp., 49 pls.

PP 41. Geology of the central Copper River region, Alaska, by W. C. Mendenhall. 1905.133 pp., 20 pls.

B 254. Report of progress in the geological resurvey of the Cripple Creek district, Colorado, by Waldemar Lindgren and F. L. Ransome. 1904. 36 pp. 
B 255. The fluorspar deposits of southern Illinois, by H. Foster Bain. 1905. 75 pp., 6 pls. (Out of stock.)

B 256. Mineral resources of the Elders Ridge quadrangle, Pennsylvania, by R. W. Stone. 1905. 86 pp., 12 pls.

B 259. Report on progress of investigations of mineral resources of Alaska in 1904, by A. H. Brooks and others. $1905.196 \mathrm{pp} ., 3 \mathrm{pls}$.

B 260. Contributions to economic geology, 1904; S. F. Emmons and C. W. Hayes, geologists in charge. 1905. 620 pp., 4 pls.

B 261. Preliminary report on the operations of the coal-testing plant of the United States Geological Survey at the Louisiana Purchase Exposition, St. Louis, Mo., 1904; E. W. Parker, J. A. Holmes, and M. R. Campbell, committee in charge. $1905.172 \mathrm{pp.} \mathrm{(Out} \mathrm{of} \mathrm{stock.)}$

B 263. Methods and cost of gravel and placer mining in Alaska, by C. W. Purington. 1905. 273 pp., 42 pls. (Out of stock.)

PP 42. Geology of the Tonopah mining district, Nevada, by J. E. Spurr. 1905.295 pp., 24 pls.

PP 43. The copper deposits of the Clifton-Morenci district, Arizona, by Waldemar Lindgren. 1905. 375 pp., 25 pls.

B 264. Record of deep-well drilling for 1904, by M. L. Fuller, E. F. Lines, and A. C. Veatch. 1905. $106 \mathrm{pp}$.

B 265. Geology of the Boulder district, Colorado, by N. M. Fenneman. 1905.101 pp., 5 pls.

B 267. The copper deposits of Missouri, by H. Foster Bain and E. O. Ulrich. 1905.52 pp., 1 pl.

B 269. Corundum and its occurrence and distribution in the United States (a revised and enlarged edition of Bulletin No. 180), by J. H. Pratt. 1906.175 pp., 18 pls.

PP 48. Report on the operations of the coal-testing plant of the United States Geological Survey at the Louisiana Purchase Exposition, St. Louis, Mo., 1904; E. W. Parker, J. A. Holmes, M. R. Campbell, committee in charge. 1906. (In three parts.) 1,492 pp., $13 \mathrm{pls}$.

B 275. Slate deposits and slate industry of the United States, by T. N. Dale, with sections by E. C. Eckel, W. F. Hillebrand, and A. T. Coons. 1906.154 pp., 25 pls.

PP 49. Geology and mineral resources of part of the Cumberland Gap coal field, Kentucky, by G. H. Ashley and L. C. Glenn, in cooperation with the State Geological Department of Kentucky, C. J. Norwood, curator. 1906.239 pp., 40 pls.

B 277. Mineral resources of Kenai Peninsula, Alaska: Gold fields of the Turnagain Arm region, by F. H. Moffit; Coal fields of the Kachemak Bay region, by R. W. Stone. 1906.80 pp., 18 pls.

B 278. Geology and coal resources of the Cape Lisburne region, Alaska, by A. J. Collier. 1906.54 pp., 9 pls. (Out of stock.)

B 279. Mineral resources of the Kittanning and Rural Valley quadrangles, Pennsylvania, by Charles Butts. 1906.198 pp., 11 pls.

B 280. The Rampart gold placer region, Alaska, by L. M. Prindle and F. L. Hess. 1906.54 pp., 7 pls. (Out of stock.)

B 282. Oil fields of the Texas-Louisiana Gulf Coastal Plain, by N. M. Fenneman. 1906.146 pp., 11 pls.

PP 51. Geology of the Bighorn Mountains, by N. H. Darton. 1906.129 pp., 47 pls.

B 283. Geology and mineral resources of Mississippi, by A. F. Crider. 1906.99 pp., 4 pls.

B 284. Report on progress of investigations of the mineral resources of Alaska in 1905, by A. H. Brooks and others. 1906. $169 \mathrm{pp} ., 14 \mathrm{pls}$.

B 285. Contributions to economic geology, 1905; S. F. Emmons and E. C. Eckel, geologists in charge. 1906. 506 pp., 13 pls. (Out of stock.)

B 286. Economic geology of the Beaver quadrangle, Pennsylvania, by L. H. Woolsey. 1906.132 pp., 8 pls.

B 287. Juneau gold belt, Alaska, by A. C. Spencer, and A reconnaissance of Admiralty Island, Alaska, by C. W. Wright. $1906.161 \mathrm{pp} ., 27 \mathrm{pls}$.

PP 54. The geology and gold deposits of the Cripple Creek district, Colorado, by W. Lindgren and F. L. Ransome. 1906.516 pp., 29 pls.

PP 55. Ore deposits of the Silver Peak quadrangle, Nevada, by J. E. Spurr. 1906. 174 pp., 24 pls.

B 289. A reconnaissance of the Matanuska coal field, Alaska, in 1905, by G. C. Martin. 1906.34 pp., 5 pls.

B 290. Preliminary report on the operations of the fuel-testing plant of the United States Geological Survey at St. Louis, Mo., 1905, by J. A. Holmes. 1906. 240 pp.

B 293. Reconnaissance of some gold and tin deposits of the southern Appalachians, by L. C. Graton, with notes on the Dahlonega mines, by W. Lindgren. $1906.134 \mathrm{pp} ., 9 \mathrm{pls}$.

B 294. Zinc and lead deposits of the upper Mississippi Valley, by H. Foster Bain. 1906. 155 pp., 16 pls.

B 295. The Yukon-Tanana region, Alaska, description of Circle quadrangle, by L. M. Prindle. 1906. 27 pp., 1 pl.

B 296. Economic geology of the Independence quadrangle, Kansas, by Frank C. Schrader and Erasmus Haworth. $1906.74 \mathrm{pp} ., 6$ pls.

B 297. The Yampa coal field, Routt County, Colo., by N. M. Fenneman, Hoyt S. Gale, and M. R. Campbell. 1906. 96 pp., 9 pls.

B 29x. Record of deep-well drilling for 1905, by Myron L. Fuller and Samuel Sanford. 1906. $299 \mathrm{pp}$.

B 300. Economic geology of the Amity quadrangle in eastern Washington County, Pa., by Frederick G. Clapp. $1907.145 \mathrm{pp}, 8 \mathrm{pls}$. 
B 303. Preliminary account of Goldfield, Bullfrog, and othermining districts in southern Nevada, by F. L. Ransome, with notes on the Manhattan district, by G. H. Garrey aud W. H. Emmons. 1906. 98 pp., 5 pls.

B. 304. Oil and gas fields of Greene County, Pa., by Ralph W. Stone and Frederick G. Clapp. 1900 110 pp., 3 pls.

PP 56. Geography and geology of a portion of southwestern Wyoming, with special reference to coal and oil, by A. C. Veatch. 1907. - pp., 26 pls.

B 308. A geologic reconnaissance in southwestern Nevada and eastern California, by S. H. Ball. 190\% 218 pp., 3 pls.

B 309. The Santa Clara Valley, Puente Hills, and Los Angeles oil districts, southern California, by G. H. Eldridge and Ralph Arnold. 1907. 266 pp., 41 pls.

B 312. The interaction between minerals and water solutions, with spccial reference to geologie phenomena, by E. C. Sullivan. 1907. 69 pp.

B 313. The granites of Maine, by T. Nelson Dale, with an introduction by G. O. Smith. 1907. - pp., 14 pls.

B 314. Report of progress of investigations of mineral resources of Alaska, in 1906, by A. H. Brooks and others. 1907. 235 pp., 4 pls.

B 315. Contributions to economic geology, 1906, Part I: Metals and nonmetals, except fuels; 8. F. Emmons and E. C. Eckel, geologists in charge. 1907. 504 pp., 4 pls.

WS 215. Geology and water resources of a portion of the Missouri River Valley in northeastem Nebraska, by G. E. Condra. 1907. - pp., 11 pls.

WS 216. Geology and water resources of the Republican River Valley in Nebraska and adjacent areas, by G. E. Condra. $1907 . \quad-$ pp.; 13 pls.

B 316. Contributions to economic geology, 1906, Part II: Fuels; M. R. Campbell, geologist in charge. 1907. - pp., - pls.

B 317. Preliminary report on the Santa Maria oil district, Santa Barbara County, Cal., by Ralph Arnold and Robert Anderson. 1907. - pp., 2 pls.

B 318. Geology of oil and gas fields in Steubenville, Burgettstown, and Claysville quadrangles, 0hio, West Virginia, and Pennsylvania, by W. T. Griswold and N. J. Munu. 1907. - pp., 13 pls,

B 320. The Downtown district of Leadville, Colo., by S. F. Emmons and J. D. Irving. $1907.75 \mathrm{pp}$., 7 pls.

\section{SERIES B, DESCRIPTIVE GEOLOGY.}

B 23. Observations on the junction between the Eastern sandstone and the Keweenaw series on Keweenaw Point, Lake Superior, by R. D. Irving and T. C. Chamberlin. 1885. 124 pp, 17 pls. (Out of stock.)

B 33. Notes on geology of northern California, by J. S. Diller. 1886. 23 pp. (Out of stock.)

B 39. The upper beaches and deltas of Glacial Lake Agassiz, by Warren Upham. 1887. 84 pp., 1 pl. (Out of stock.)

B 40. Changes in river courses in Washington Territory due to glaciation, by Bailey Willis. 188\%. 10 pp., 4 pls. (Out of stock.)

B 45. The present condition of knowledge of the geology of Texas, by R. T. Hill. $1887.94 \mathrm{pp}$. (0nt of stock.)

B 53. The geology of Nantucket, by N. S. Shaler. 1889.55 pp., T0 pls. (Out of stock.)

B 57. A geological reconnaissance in southwestern Kansas, by Robert Hay. 1890.49 pp., 2 pls.

B 58. The glacial boundary in western Pennsylvania, Ohio, Kentucky, Indiana, and Illinois, by $G$. F Wright, with introduction by T. C. Chamberlin. 1890.112 pp., 8 pls. (Out of stock.)

B 67. The relations of the traps of the Newark system in the New Jersey region, by N. H. Darton. 1890. 82 pp. (Out of stock.)

B 104. Glaciation of the Yellowstone Valley north of the Park, by W. H. Weed. $1893.41 \mathrm{pp}, 4 \mathrm{pla}$.

B 108. A geological reconnaissance in central Washington, by I. C. Russell. $1893.108 \mathrm{pp} ., 12 \mathrm{pls}$. (Out of stock.)

B 119. A geological reconnaissance in northwest Wyoming, by G. H. Eldridge. 1894.72 pp., 4 pls.

B 137. The geology of the Fort Riley Military Reservation and vicinity, Kansas, by Robert Hay. 1896. 35 pp., 8 pls.

B 144. The moraines of the Missouri Coteau and their attendant deposits, by J. E. Todd. 1896. 71 pp., 21 pls.

B 158. The moraines of southeastern South Dakota and their attendant deposits, by J. E. Todd. 189 171 pp., 27 pls.

B 159. The geology of eastern Berkshire County, Massachusetts, by B. K. Emerson. 1899 . $139 \mathrm{pp}$ 9 pls.

B 165. Contributions to the geology of Maine, by H. S. Williams and H. E. Gregory. $1900.212 p p$. 14 pls.

WS 70. Geology and water resources of the Patrick and Goshen Hole quadrangles in eastern Wyoming and western Nebruska, by G. I. Adams. 1902. 50 pp., 11 pls.

B 199. Geolngy and water resources of the Snake River Plains of Idaho, by I. C. Russell. 1902. I8' pp., 25 pls. 
PP.jeliminary report on the Ketchikan mining district, Alaska, with an introductory gketch of the geology of southeastern Alaska, by A. H. Brooks. 1902.120 pp., 2 pls.

PP 2. Reconnaissance of the northwestern portion of Seward Peninsula, Alaska, by A. J. Colljer. 1902. $70 \mathrm{pp} ., 11 \mathrm{pls}$.

PP 3. Geology and petrography of Crater Lake National Park; by J. S. Diller and H. B. Patton. 1902. 167 pp., 19 pls.

PP 10. Reconnaissance from Fort Hamlin to Kotzebue Sound, Alaska, by way of Dall, Kanuti, Allen, and Kowak rivers, by W. C. Mendenhall. $1902.68 \mathrm{pp}$., $10 \mathrm{pls}$.

PP 11. Clays of the United States east of the Mississippi River, by Heinrich Ries. 1903.298 pp., 9 pls. (Out of stock.)

PP 12. Geology of the Globe copper district, Arizona, by F. L. Ransome. 1903.168 pp., 27 pls.

PP 13. Drainage modifications in southeastern Ohio and adjacent parts of West Virginia and Kentucky, by W. G. Tight. $1903.111 \mathrm{pp} ., 17 \mathrm{pls}$. (Out of stock.)

B 208. Descriptive geology of Nevada south of the fortieth parallel and adjacent portions of California, by J. E. Spurr. 1903.229 pp., 8 pls. (Out of stock.)

B 209. Geology of Ascutney Mountain, Vermont, by R. A. Daly, 1903.122 pp., 7 pls.

WS 78. Preliminary report on artesian basins in southwestern Idaho and southeastern Oregon, by I. C. Russell. 1903.51 pp., 2 pls.

PP 15. Mineral resources of the Mount Wrangell district, Alaska, by W. C. Mendenhall and F. C. Schrader. $1903.71 \mathrm{pp} .10 \mathrm{pls}$.

PP 17. Preliminary report on the geology and water resources of Nebraska west $\mathrm{n}$ the one hundred and third meridian, by N. H. Darton. $1903.69 \mathrm{pp}$., 43 pls.

B 217. Notes on the geology of southwestern Idaho and southeastern Oregon, by I. C. Russell. 1903. 83 pp., 18 pls.

B 219. The ore deposits of Tonopah, Nevada (preliminary report), by J. E. Spurr. 1903.31 pp., 1 pl.

FP 20. A reconnaissance in northern Alaska in 1901, by F. C. Schrader. 1904.139 pp., 16 pls.

PP 21. The geology and ore deposits of the Bisbee quadrangle, Arizona, by F. L. Ransome. 1904. 168 pp., 29 pls.

WS 90. Geology and water resources of part of the lower James River Valley, South Dakota, by J. E. Todd and C. M. Hall. 1904. $47 \mathrm{pp}$., 23 pls.

PP 25. The copper deposits of the Encampment district, Wyoming, by A. C. Spencer. $1904.107 \mathrm{pp}$, 2 pls. (Out of stock.)

PP 26. Economic resources of the northern Black Hills, by J. D. Irving, with contributions by S. F. Emmons and T. A. Jaggar, jr. 1904. 222 pp., 20 pls.

PP 27. A geological reconnaissance across the Bitterroot Range and Clearwater Mountains in Montana and Idaho, by Waldemar Lindgren. $1904.122 \mathrm{pp} ., 15 \mathrm{pls}$.

PP 31. Preliminary report on the geology of the Arbuckle and Wichita mountains in Indian Territory and Oklahoma, by J. A. Taff, with an appendix on reported ore deposits in the Wichita Mountains, by H. F. Bain. 1904.97 pp., 8 pls.

B 235. A geological reconnaissunce across the Cascade Range near the forty-ninth parallel, by $G .0$. - Smith and F. C. Calkins. 1904. 103 pp., 4 pls.

B 236. The Porcupine placer district, Alaska, by C. W. Wright. 1904.35 pp., 10 pls.

B 237. Igneous rocks of the Highwood Mountains, Montana, by L. V. Pirsson. 1904. 208 pp., 7 pls.

B 238. Economic geology of the Iola quadrangle, Kansas, by G. I. Adams, Erasmus .Haworth, and W. R. Crane. 1904.83 pp., 1 pl.

PP 32. Geology and underground water resources of the central Great Plains, by N. H. Darton. 1905. 433 pp., 72 pls.

Ws 110. Contributions to hydrology of eastern United States, 1904; M. L. Fuller, geologist in charge. 1905. $211 \mathrm{pp} ., 5 \mathrm{pls}$.

B 242. Geology of the Hudson Valley between the Hoosic and the Kinderhook, by T, Nelson Dale. 1904. 63 pp., 3 pls.

PP 34. The Delavan lobe of the Lake Michigan glacier of the Wisconsin stage of glaciation and associated phenomena, by W. C. Alden. $1904.106 \mathrm{pp} ., 15 \mathrm{pls}$.

PP 35. Geology of the Perry Basin in southeastern Maine, by G. O. Smith and David White. 1905. 107 pp., 6 pls.

B 243, Cement materials and industry of the United States, by E. C. Eckel. 1905. 395 pp., 15 pls.

B 246. Zinc and lead deposits of northeastern Illinois, by H. F. Bain. 1904.56 pp., 5 pls.

B 247. The Fairhaven gold placers of Seward Peninsula, Alaska, by F. H. Moffit. 1905.85 pp., 14 pls.

B 249. Limestones of southwestern Pennsylvania, by F. G. Clapp. 1905.52 pp., 7 pls.

B 250. The petroleum fields of the Pacific coast of Alaska, with an account of the Bering River coal deposit, by G. C. Martin. 1905 . 65 pp., 7 pls.

B 251. The gold placers of the Fortymile, Birch Creek, and Fairbanks regions, Alaska, by L. M. Prindle. 1905. 16 pp., 16 pls.

ws 118. Geology and water resources of a portion of east-central Washington, by F. C. Calkins. 1905. .96 pp., 4 pls.

B 252. Preliminary report on the geology and water resources of central Oregon, by I. C. Russell. 1905. 138 pp., 24 pls.

Bull. $320-07-6$ 
PP 36. The lead, zinc, and fluorspar deposits of western Kentucky, by E. O. Ulrich and W. S. Tangiep Smith. 1905. 218 pp., 15 pls.

PP 38. Economic geology of the Bingham mining district of Utah, by J. M. Boutwell, with a chapter on areal geology, by Arthur Keith, and an introduction on general geology, by S. F. Emmons 1905. $413 \mathrm{pp} ., 49 \mathrm{pls}$.

PP 41. The geology of the central Copper River region, Alaska, by W. C. Mendenhall. 1905. $133 \mathrm{pp}$, 20 pls.

B 254. Report of progress in the geological resurvey of the Cripple Creek district, Colorado, by Waldemar Lindgren and F. L. Ransome. $1904.36 \mathrm{pp}$.

B 255. The fluorspar deposits of southern Illinois, by H. Foster Bain. 1905.75 pp., 6 pls. (Out ol stock.)

B 256. Mineral resources of the Elders Ridge quadrangle, Pennsylvania, by $R$ W. Stone. 1900 . 85 pp., 12 pls.

B 257. Geology and paleontology of the Judith River beds, by T. W. Stanton and J. B. Hatcher, with a chapter on the fossil plants, by F. H. Knowlton. 1905. $174 \mathrm{pp} ., 19 \mathrm{pls}$.

PP 42. Geology of the Tonopah mining district, Nevada, by J. E. Spurr. 1905. 295 pp., 24 pls.

WS 123. Geology and underground water conditions of the Jornada del Muerto, New Mexico,by C. R. Keyes. 1905.42 pp., 9 pls.

WS 136. Underground waters of Salt River Valley, Arizona, by W. T. Lee. 1905.194 pp., 24 pls.

PP 43. The copper deposits of Clifton-Morenci, Arizona, by Waldemar Lindgren. $1905.375 \mathrm{pp}$, $25 \mathrm{pls}$

B 265. Geology of the Boulder district, Colorado, by N. M. Fenneman. 1905. 101 pp., 5 pls.

B 267. The copper deposits of Missouri, by H. F. Bain and E. O. Ulrich. $1905.52 \mathrm{pp} ., 1 \mathrm{pl}$.

PP 44. Underground water resources of Long Island, New York, by A. C. Veatch and others. 1906, 394 pp., 34 pls.

WS 148. Geology and water resourc 's of Oklahoma, by C. N. Gould. 1905.178 pp., 22 pls.

B 270. The configuration of the rock floor of Greater New York, by W. H. Hobbs. $1905.96 \mathrm{pp} ., 5 \mathrm{pls}$

B 272. Taconic physiography, by T. M. Dale. 1905. 52 pp., 14 pls.

PP 45. The geography and geology of Alaska, a summary of existing knowledge, by A. H. Brooks, with a section on climate, by Cleveland Abbe, jr., and a topographic map and description thereof, by R. M. Goode. 1905 . 327 pp., 34 pls.

B 273. The drumlins of southeastern Wisconsin (preliminary paper), by W. C. Alden. $1905.46 \mathrm{pp}$, 9 pls.

PP 46. Geology and underground water resources of northern Louisiana and southern Arkansas, br A. C. Veatch. $1906.422 \mathrm{pp} ., 51 \mathrm{pls}$.

PP 49. Geology and mineral resources of part of the Cumberland Gap coal field, Kentucky, by G. B. Ashley and L. C. Glenn, in cooperation with the State Geological Department of Kentucky, C. J. Norwood, curator. 1906.239 pp., 40 pls.

PP 50. The Montana lobe of the Keewatin ice sheet, by F. H. H. Calhoun. 1906.62 pp., 7 pls.

B 277. Mineral resources of Kenai Peninsula, Alaska: Gold fields of the Turnagain Arm region, bf F. H. Moffit; and the coal fields of the Kachemak Bay region, by R. W. Stone. 1906. $80 \mathrm{pp}$. $18 \mathrm{pls}$. (Out of stock.)

WS 154. The geology and water resources of the eastern portion of the Panhandle of Texas, by C.N. Gould. $1906.64 \mathrm{pp} ., 15 \mathrm{pls}$.

B 278. Geology and coal resources of the Cape Lisburne region, Alaska, by A. J. Collier. 1906. pp., 9 pls. (Out of stock.)

B 279. Mineral resources of the $\mathrm{K}$ ttanning and Rural Valley quadrangles, Pennsylvania, by Charles Butts. 1906. $198 \mathrm{pp} ., 11$ pls.

B 280. The Rampart gold placer region, Alaska, by L. M. Prindle and F. L. Hess. 1906.54 pp., 7 pla (Out of stock.)

B 282. Oil fields of the Texas-Louisiana Gulf Coastal Plain, by N. M. Fenneman. $1906.146 \mathrm{pp} ., 11 \mathrm{pla}$

WS 157. Underground water in the valleys of Utah Lake and Jordan River, Utah, by G. B. Richardson. 1906. $81 \mathrm{pp} ., 9 \mathrm{pls}$.

PP 51. Geology of the Bighorn Mountains, by N. H. Darton. 1906.129 pp., 47 pls.

WS 158. Preliminary report on the geology and underground waters of the Roswell artesian arte New Mexico, by C. A. Fisher. 1906. 29 pp., 9 pls.

PP 52. Geology and underground waters of the Arkansas Valley in eastern Colorado, by N. H. Datton. 1906. 90 pp., 28 pls.

WS 159. Summary of underground-water resources of Mississippi, by A. F. Crider and L. C. Johneon 1906. 86 pp., 6 pls.

PP 53. Geology and water resources of the Bighorn basin, Wyoming, by Cassius A. Fisher. 100 . 72 pp., 16 pls.

B 283. Geology and mineral resources of Mississippi, by A. F. Crider. 1906.99 pp., 4 pls.

B 286. Economic geology of the Beaver quadrangle, Pennsylvania (southern Beaver and northwes ern Allegheny counties), by L. H. Woolsey. 1906. $132 \mathrm{pp} ., 8 \mathrm{pls}$.

B 287. The Junean gold belt, Alaska, by A. C. Spencer, and a reconnaissance of Admiralty Islad, Alaska, by C. W. Wright. 1906.161 pp., 37 pls.

PP 54. The geology and gold deposits of the Cripple Creek district, Colorado, by W. Lindgren and F. L. Ransome. 2906.516 pp., 29 pls. 
PP 65. Ore deposits of the Silver Peak quadrangle, Nevada, by J. E. Spurr. 1906.174 pp., 24 pls.

B 289. A reconnaissance of the Matanuska coal field, Alaska, in 1905, by G. C. Martin. 1906 . 36 pp., 5 pls.

W8 164. Underground waters of Tennessee and Kentucky west of Tennessee River and of an adjacent area in Illinois, by L. C. Glenn. 1906.173 pp., 7 pls.

B 298. A reconnaissance of some gold and tin deposits of the southern Appalachians, by L. C. Groton, with notes on the Dahlonega mines, by W. Lindgren. 1906. $134 \mathrm{pp.,} 9 \mathrm{pls}$.

B 294. Zinc and lead deposits of the upper Mississippi Valley, by H. Foster Bain. $1906.155 \mathrm{pp}$. 16 pls.

B 295. The Yukon-Tanana region, Alaska, description of Circle quadrangle, by L. M. Frindle. 1906. 27 pp., 1 pl.

B 296. Economic geology of the Independence quadrangle, Kansas, by Frank C. Schrader and Erasmus Haw orth. $1906.74 \mathrm{pp} ., 6 \mathrm{pls}$.

WE 181. Geology and water resources of Owens Valley, California, by Willis T. Lee. 1906. $28 \mathrm{pp}$. 6 pls.

B 297. The Yampa coal field, Routt County, Colo., by N. M. Fenneman, Hoyt S. Gale, and M. R. Campbell: 1906.96 pp., 9 pls.

B 300. Economic geology of the Amity quadrangle in eastern Washington County, Pa., by F. G. Clapp. 1906.145 pp., 8 pls.

B 303. Preliminary account of Goldfield, Bullfrog, and other mining districts in southern Nevada, by F. L. Ransome; with notes on Manhattan district, by G. H. Garrey and W. H. Emmons. 1907. 98 pp., 5 pls.

B 304. Oil and gas fields of Greene County, Pa., by R. W. Stone and F. G. Clapp. 1907.110 pp., 3 pls. WS 188. Water resources of the Rio Grande Valley in New Mexico and their development, by W. T. Lee. $1906.59 \mathrm{pp} ., 10 \mathrm{pls}$.

B 306. Rate of recession of Niagara Falls, accompanied by a report on the survey of the crest, by W. Carvel Hall.' 1906. 31 pp., 11 pls.

PP 56. Geography ánd geology of a portion of southwestern Wyoming, with special reference to coal and oil, by A. C. Veatch. 1907. - pp., 26 pls.

B 308. A geologic reconnaissance in southwestern Nevada and eastern California, by S. H. Ball. 1907. 218 pp., 3 pls.

B 309. The Santa Clara Valley, Puente Hills, and Los Angeles oil districts, southern California, by G. H. Eldridge and Ralph Arnold. 1907. 266 pp., 41 pls.

PP 57. Geology of the Marysville mining district, Montana, a study of igneous intrusion and contact metamorphism, by Joseph Barrell. 1907. 178 pp., 16 pls.

WS. 191. The geology and water resources of the western portion of the Panhandle of Texas, by C. N. Gould. 1907. 70 pp., 7 pls.

B 311. The green schists and associated granites and porphyries of Rhode Island, by B. K. Emerson and J. H. Perry. 1907. 74 pp., 2 pls.

ws 195. Underground waters of Missouri, their geology and utilization, by Edward Shepard. ' 1907. - pp., 6 pls.

WS 199. Underground water in Sanpete and central Sevier valleys, Utah, by G. B. Richardson. 1907. - pp., 6 pls.

WS 215. Geology and water resources of a portion of the Missouri River Valley in northeastern Nebraska, by G. E. Condra. 1907. - pp., 11 pls.

Ws 216. Geology and water resources of the Republican River Valley in Nebraska and adjacent areas, by G. E. Condra. 1907. - pp., 13 pls.

B 317. Preliminary report on the Santa Maria oil district, Santa Barbara County, Cal., by Ralph Arnold and Robert Anderson. 1907. - pp., 2 pls.

B 318. Geology of oil and gas fields in Steubenville, Burgettstown, and Claysville quadrangles, Ohio, West Virginia, and Pennsylvania, by W. T. Griswold and M. J. Munn. 1907. - pp., 13 pls.

B 319. Summary of controlling factors of artesian flows, by M. L. Fuller. 1907. - pp., 7 pls.

B 320. The Downtown district of Leadville, Colo., by S. F. Emmons and J. D. Irving. 1907. 75 pp. 7 pls.

Correspondence should be addressed to

The Director,

. United States Geological Survey,

JUNE, 1907.

Washington, D. C. 

